\title{
REMEMBER THE ALAMO[NY]! THE UNIQUE TEXAS BAN ON PERMANENT ALIMONY AND THE DEVELOPMENT OF COMMUNITY PROPERTY LAW
}

\author{
JAMES W. PAULSEN ${ }^{*}$
}

TABLE OF CONTENTS

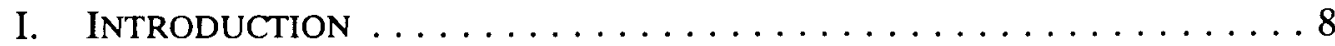

II. The Original Contours of TeXas Divorce LAW (1836-1875) . . 8

A. Sam Houston's Divorce . . . . . . . . . . . . . . 9

B. Property Division for Ex-Spousal Support $\ldots \ldots \ldots \ldots \ldots$

C. The Disappearing Alimony Decision . . . . . . . . . . . 18

III. Alimony in Everything BUt NAME (1876-1969) . . . . . . . . . . 23

A. The Birth of the "No Permanent Alimony" Doctrine . . . . . . 24

B. Imaginative Property Division $\ldots \ldots \ldots \ldots \ldots \ldots \ldots \ldots$

C. Alimony by Contract . . . . . . . . . . . . . . . . . . 37

IV. Neither Alimony Nor Equity (1969 to the Present) . . . . . . . 39

A. "No Fault" Divorce . . . . . . . . . . . . . . . . . . . . 40

B. Revisionist Community Property Doctrine . . . . . . . . . . . . 42

C. Legislative Efforts . . . . . . . . . . . . . . . . . 51

V. INTO The Future: The Prospects for SPOUSAl SuPPORT. . . . . . 55

A. Permanent Alimony and Public Policy . . . . . . . . . . 55

B. Emerging Texas Community Property Doctrine .......... 58

C. The Possibility of Judicial Reform . . . . . . . . . . . . . 64

VI. Conclusion ............................ 69

Copyright $\mathrm{C} 1993$ by Law and Contemporary Problems

* Assistant Professor of Law, South Texas College of Law.

This article benefited immeasurably from the suggestions and comments of many friends, teachers and colleagues, including Professors James Hambleton, Joseph W. McKnight, W. Frank Newton, J. Thomas Oldham, William A. Reppy, Jr., John J. Sampson, Eugene L. Smith, and especially David Westfall. Research assistance far beyond the call of duty was received from Kay Schleuter and the staff of the Texas State Law Library, Michael Green and the staff of the Lorenzo de Zavala Texas State Archives, and the staff of the Harvard Law Library. The author's spouse Robin Russell, took time from her law practice to assist in the editing process. Some of the analysis and conclusions in this article may be controversial; these, together with any mistakes, are the author's sole responsibility.

Two editorial matters deserve mention. First, contrary to the author's usual practice, this article does not always employ gender-neutral language. Since gender-based assumptions, often based in reality, have played a part in the development of the Texas law of spousal support, consistent use of genderneutral language tends to sacrifice accuracy on the altar of political correctness. Second, at the author's request, citation form for Texas authority sometimes follows Texas conventions, which occasionally convey more information than recommended forms in "national" citation manuals. 


\section{INTRODUCTION}

Texas now stands alone among U.S. jurisdictions in its absolute ban on permanent, court-ordered alimony. ${ }^{1}$ This prohibition, seemingly based on a policy established during the days of the Republic of Texas, is commonly justified as a consequence of the benefits of the Texas community property system. ${ }^{2}$ In modern Texas, however, the ban on permanent alimony combines with restrictive interpretations of community property doctrine to deprive divorce courts of any ability to adjust equities if there is no community property to divide. Nonetheless, despite very real hardships, the Texas Legislature has resisted several recent attempts to enact even the most limited of spousal maintenance statutes.

Contrary to commonly held beliefs, the analysis that follows suggests that the time-honored Texas prohibition of permanent alimony may be nothing more than a turn-of-the-century invention of Texas courts, coinciding with a generally conservative judicial attitude, a skyrocketing divorce rate, and the heyday of the women's suffrage movement. The conclusions drawn are not merely matters of historical interest, though. Rather, a study of the earliest days of Texas divorce law suggests at least one alternative to alimony - an action for breach of marital contract - that might be used by Texas courts today as a partial substitute for past failures of Texas courts and lawmakers to provide any form of postdivorce support of an ex-spouse.

Since the principal justifications for the refusal of Texas courts and legislators to consider alimony are historical in nature, this article is organized historically. So far as the legal issues are concerned, Texas history can be divided into three distinct phases. The formative period, from 1836 through 1875 , begins with the Texas Revolution and ends with the adoption of the state's current constitution, punctuated by the Civil War and Reconstruction. The second period, from 1876 through 1969, spans the transition of Texas from a largely rural to a largely urban state, with accompanying great increases in the divorce rate. The final division-1970 to the present-covers a relatively short period of time. Nonetheless, the enactment of the Texas Family Code, a series of remarkable Texas Supreme Court decisions, and nearly continuous legislative agitation fully justify its treatment as a new era in Texas divorce jurisprudence.

\section{II}

The Original Contours of TeXas DivorCe LAW (1836-1875)

The first period of Texas divorce law is somewhat chaotic, and for good reason. In its earliest days, Texas was a frontier republic, at war with Coman-

1. Cameron v. Cameron, 641 S.W.2d 210, 218 n.7 (Tex. 1982); Thomas E. Carbonneau, $A$ Consideration of Alternatives to Divorce Litigation, 1986 U. ILL. L. REV. 1119, 1141-42.

2. See, e.g. Eichelberger v. Eichelberger, 582 S.W.2d 395, 402 (Tex. 1979) (referring to "the general incompatibility of the principle of spousal support after divorce with the community property system as it has existed in Texas since the Republic of Texas"). 
ches and Mexicans alike. A short period of stability was followed by dramatic changes in judicial personnel during the Civil War and three phases of Reconstruction. From the beginning, Texas law also had its own unique twists: Texas was the first jurisdiction to merge law and equity, ${ }^{3}$ the first to adopt a homestead exemption law, ${ }^{4}$ and a pioneer in community property law. Texas lawmakers and judges thus often found themselves in the position of legal innovators.

Rather than try to set out all the details of a confusing and sometimes contradictory legal framework, this section focuses on three cases in the hope that they will open windows on some unlikely legal vistas. The first example, a permanent divorce granted by a court before the enactment of the first Texas divorce statute, ${ }^{5}$ is at odds with later authority holding that even alimony-as one incident of a permanent divorce-could not be granted by a court absent specific legislative authority. The second example is a celebrated property division case, ${ }^{6}$ decided by a unanimous court whose members included a drafter of the first state constitution, yet tacitly disapproved by the Texas Supreme Court some 120 years later as an unconstitutional usurpation of authority. ${ }^{7}$ The last example is a Texas Supreme Court case from the 1870s in which the court did exactly what the Texas Supreme Court now regards as legally impossible: award permanent alimony to a deserving spouse. ${ }^{8}$ Taken together, these cases pose an obstacle for anyone trying to maintain, as a serious historical proposition, that early Texas public policy really forbade permanent alimony.

\section{A. Sam Houston's Divorce}

Any examination of early Texas divorce law must begin with the story of a rather famous individual. It was the spring of 1837 , and Sam Houston was in love. The object of his affections was Anna Raguet, the accomplished and beautiful daughter of a prominent Nacogdoches family. ${ }^{9}$ As the hero of San Jacinto and president of the Republic of Texas, Sam Houston had much to commend him as a suitor. Unfortunately, he also had a problem; namely, a wife in Tennessee. Sam Houston had married Eliza Allen in 1829. Though they separated permanently after less than three months of married life, Houston had not succeeded in obtaining a divorce. ${ }^{10}$

3. Nelson Phillips, Historical Introduction, 1 TEX. JUR. xxvii, lii (1929).

4. Id. at liv; see also Joseph W. Mcknight, Protection of the Family Home From Seizure by Creditors: The Sources and Evolution of a Legal Principle, 86 SW. HIST. Q. 369 (1983).

5. The case, Houston v. Houston, is not reported.

6. Fitts v. Fitts, 14 Tex. 443 (1855). See text accompanying notes 47-65.

7. See Eggemeyer v. Eggemeyer, 554 S.W.2d 137 (Tex. 1977). See discussion infra part IV.B.

8. Wiley v. Wiley, 33 Tex. 358 (1870). See discussion infra part II.C.

9. Details of the relationship can be found in EVER THINE TRULY: LOVE LETTERS FROM SAM Houston to ANNA RAGUET (Jenkins Garrett Press ed., 1975) [hereinafter EVER THINE TRULY].

10. Houston may have tried to secure a legislative divorce in Tennessee in 1830 . He tried again in prerevolutionary Texas in 1833, even though divorce was not recognized under Spanish law. See id. at 93-94 (text of Tennessee petition); 1 AMElia W. Williams \& EUGENE C. BARKER, THE WritingS OF SAM Houston 277 (1938) [hereinafter WRITINGS OF SAM HOUSTON] (text of petition to alcalde of 
While Sam Houston's private life may not, at first blush, seem relevant to modern divorce law, Houston's desire to keep his marital problems quiet, ${ }^{11}$ and the way in which he consequently decided to obtain a divorce, create a genuine legal puzzle. In the spring of 1837 , with the nation barely a year old, the Republic of Texas had no general divorce statute. ${ }^{12}$ While it would have been a simple matter for President Sam Houston to secure a legislative divorce, he would have been forced to air his marital dirty linen before the assembled Congress and a curious press. ${ }^{13}$ Instead, Houston issued a presidential proclamation authorizing a judge in East Texas to hear and decide his divorce petition. As a result, he obtained his divorce.

Was Sam Houston's divorce valid? The question was the subject of "a deal of whispered concern."14 Even one of Houston's close friends expressed the private opinion that the divorce decree was "a farce."15 Indeed, there was

Ayish District, Free State of Coahuila and Texas). As there are no Tennessee records corroborating the filing of the first petition, this may have been a later Houston invention. See Elizabeth Crook, Sam Houston and Eliza Allen: The Marriage and the Mystery, 94 Sw. HIST. Q. 1, 29-30 n.64 (1990) (quoting Dr. John McGlone, Director of Public Services of the Tennessee State Library and Archives). Scholars are divided on the question of whether or not the alcalde's petition ever was acted upon. Compare, e.g., JoHN HoYt Williams, SAM Houston: A BIOGRaphy OF THE FATHER OF TEXas 113 (1993) ("McFarland [the alcalde], with dubious legality, granted the divorce, one of the first in Mexican history."). Even if granted, however, it would have been a legal nullity. Accord Samuel E. Ashbury, Jonas Harrison, Legendary and Historical, 45 SW. HIST. Q. 231, 241 (1942) (the divorce "had no longer legality under Mexican canon law").

11. To this day, the failure of Houston's first marriage remains a source of speculation for biographers and grist for novelists' mills. One recent historical novel, for example, is based entirely on Houston's first marriage. See ElIzABETH CROOK, RAVEN's BRIDE (1991). The most common theory is that Eliza Allen had been forced into the marriage by her father, though she loved another. See, e.g., StANley Siegel, A Political History OF tHe TeXAS RePublic, 1836-1845, at 50 (1956).

We know that the break-up was traumatic: Houston immediately resigned as governor of Tennessee, renounced his U.S. citizenship, and took up residence with the Cherokee Indians, acquiring (apparently by sheer merit) the tribal nickname "Big Drunk." Id. at 49-50. Years later, he still refused to talk about his first marriage. Elizabeth Crook states that "the particulars of this disastrous marriage are a secret that Houston carried all of his life, first with an air of intense grief, then bitterness, and, finally, his characteristic melodrama." Crook, supra note 10 , at 2.

In the interest of historical completeness, it should be noted that while in residence with the Cherokees, Houston took another "wife." She died in 1838, however, making the legal situation slightly less confusing than it might have been otherwise. MARQUIS JAMES, THE RAVEN 299 n.33 (1929).

12. In fact, Republic lawmakers had not yet regularized the institution of marriage. In June of 1837, Congress passed legislation recognizing the validity of informal marriages, providing that those marriages had been contracted "agreeably to the custom of the times" and that these marriages were to be solemnized according to the statute within six months' time. An Act to Legalize Certain Marriages, To Provide for the Celebration of Marriages and for Other Purposes $\& 1$ (June 5, 1837), 1 H.P. GAMMEL, LAWS OF TEXAS 1293 (1898). The preamble explained that "in many parts of Texas no person legally authorized to celebrate the rites of matrimony has existed [and that] from that cause many persons ... have resorted to the practice of marrying by bond, and others have been married by various officers of Justice not authorized to celebrate such marriages." Id. at 1293 . The situation was described vividly and accurately by Chief Justice Oran M. Roberts, later first president of the Texas State Historical Association, in Lewis v. Ames, 44 Tex. 319, 338-39 (1875).

13. See JAMES, supra note 11, at 299.

14. Id.

15. Letter from Barnard E. Bee to Ashbel Smith (June 5, 1840) (Eugene C. Barker Texas History Center Archives, University of Texas) (on file with Law and Contemporary Problems). Bee, a South Carolina-trained lawyer, was Houston's secretary of war. 1 WALTER PRESCOTT WEBB, HANDBOOK OF TEXAS 135 (1952) [hereinafter HANDBOOK OF TEXAS]. Of course, coming from South Carolina, a state 
something to be said for this view. Not only were the proceedings irregular ${ }^{16}$ and the basis of the divorce questionable, ${ }^{17}$ but there is room for doubt as to whether the court even had subject-matter jurisdiction. In the English tradition, ecclesiastical courts could grant annulments or separations, but permanent divorce was a creature of Parliament. ${ }^{18}$ Although the divorce law of most U.S. jurisdictions was less strict, jurisdiction for divorce generally stemmed from a specific legislative grant of power to the courts. ${ }^{19}$ Within a few years after independence, Texas followed the general pattern of delegating legislative power to the courts. While a few early divorces were granted by special legislation, ${ }^{20}$

which at the time did not recognize permanent divorce at all, Bee might have viewed the formalities of divorce in a more conservative light than most Texans.

16. There is no evidence that Eliza Allen was aware of the proceedings. See Crook, supra note 10, at 31 . Houston claimed that "[ $t$ ]he question was solemnly argued in court, for the adverse party." Letter from Sam Houston to Anna Raguet (June 4, 1838), in EVER THINE TRULY, supra note 9, at 23. Houston's lawyer in the divorce, however, reported that he successfully blocked an attempt to delay the proceedings until Mrs. Houston could be notified. Letter from W.G. Anderson to Sam Houston (April 8,1837 ), in WRITINGS OF SAM HOUSTON, supra note 10, at $245 \mathrm{n} .2$. In light of the fact that neither of the parties seems to have been present at the hearing, one might also wonder what evidence, if any, was presented in support of a divorce. The question ultimately was of little consequence to Eliza Allen, however, as she had obtained a Tennessee divorce a short time earlier, on much more plausible abandonment grounds. See WILliams, supra note 10, at 71.

17. Houston's petition for divorce rested "mainly on the length of time that has elapsed since the separation, . . . conclusively showing the impossibility of a reunion." WRITINGS OF SAM HOUSTON, supra note 10 , at 278 . Since divorce was then fault-based in all jurisdictions Texas could have looked to for guidance, it seems odd to have rewarded Houston-arguably the abandoning spouse-by granting him a divorce on this ground. The 1841 Texas divorce statute, the first specifying permissible grounds, authorized divorce in favor of the husband only "where his wife. . . shall have voluntarily left his bed and board, for the space of three years with intention of abandonment." An Act Concerning Divorce and Alimony $\S 2$ (Jan 6, 1841), 1 GAMMEL, supra note 12, at 484 (emphasis added).

The ease with which a divorce was granted to Sam Houston might be contrasted with that grudgingly granted only a few years later to Margaret $\mathrm{T}$. Wright. Mrs. Wright's petition, claiming that her husband was guilty of "excesses, cruel treatment and other outrages ... of such a nature as to render it insupportable for her to live longer with him," was considered by the Texas Supreme Court insufficiently specific to support an action for divorce. Wright v. Wright, 3 Tex. 168, 181 (1848). It was not until she filed a new pleading, accusing her husband of "the cold-blooded and brutal murder of the plaintiff's son," that the court considered the claim sufficiently specific to warrant a divorce. Wright $\mathbf{v}$. Wright, 6 Tex. 3, 17 (1851).

18. Permanent separation was often referred to as divorce "a mensa et thoro," while annulment was sometimes confusingly referred to as divorce "a vinculo." For a good general discussion, see HOMER H. Clark, JR., The Law of Domestic Relations in the United States $\$ 13.1$, at 693-96 (2d ed. 1987).

19. Id. § 13.1, at 697 .

20. The Congress of the Republic had the power to grant legislative divorces, though the power rarely appears to have been exercised. Published records show no legislative divorces granted before enactment of the general statute and only fifteen granted afterwards, three in 1839 and twelve in 1842 , the latter memorialized in two omnibus pieces of legislation passed at a special legislative session held at Houston. See An Act Granting a Divorce to Sophia Auginbaugh (Jan. 15, 1839), in 2 GAMMEL, supra note 12, at 45; An Act Granting a Divorce to George Fisher and Elisabeth Fisher (Jan. 23, 1839), in id. at 72; An Act Granting a Divorce to Louisa Beasly (Jan. 23, 1839), in id. at 73; An Act to Divorce Thomas F. McKinney and Nancy McKinney and Others From the Bonds of Matrimony (July 18, 1842), in id. at 820; An Act to Divorce Certain Persons Therein Named (July 23, 1842), in id. at 820. The divorce bills provide virtually no information about the circumstances and do not mention alimony or division of property. The legislative power to grant divorces was formally relinquished in the first state constitution. See TEX. CONST. of 1845, art. VII, § 18. 
the Congress of the Republic of Texas enacted legislation in 1837 also authorizing courts to grant divorces and to provide for separate maintenance. ${ }^{21}$

The first Texas divorce statute, however, was enacted several months after Houston's divorce. ${ }^{22}$ If the divorce were to be valid, the court's authority must have been derived from some other source. Fortunately for students of Texas history, Miss Anna Raguet heard some nasty rumors about Sam Houston's legal shenanigans and demanded an explanation. Houston responded with a letter stoutly denying that he "had presumed to address you at a time when . . . legal impediments lay in the way of my union with any lady." ${ }^{23}$ In a decidedly unromantic gesture, Houston attached to his letter two "opinions of Gentlemen eminent in the profession of the law-obtained on the abstract question as to the legality of my divorce!"24

Taken together, Houston's divorce petition and the legal opinions are enlightening. The petition rejected common law doctrine, ${ }^{25}$ concluding that "[t]he law givers of the most enlightened communities now look upon the contract of marriage in no other light than a civil contract."26 One of Houston's lawyers, basing his opinion in part on a conversation with the judge who presided over the divorce, expanded on the theory.

\begin{abstract}
I have never doubted the exclusive right of the Courts to regulate the subject of contracts, actually formed, whether they relate to marriage or other matters ... . [T] he legislature may prescribe ... in what manner contracts shall be made or dissolved, and especially the marriage contract-but until they have acted upon the subject, and as to all contracts existing prior to their action, the Courts have, alone, the power [of] decreeing performance[,] awarding damages, or exonerating the party from the obligation. ${ }^{2}$
\end{abstract}

21. An Act Amending the Judiciary Laws of the Republic $\$ 2$ (Dec. 18, 1837), in 1 GAMMEL, supra note 12 , at 1437 .

22. Id.

23. Letter from Sam Houston to Anna Raguet (June 4, 1838), in EVER THINE TRULY, supra note 9 , at 91.

24. Id. The two "Gentlemen eminent in the profession of the law" were indeed eminent, but hardly disinterested. John Birdsall was Houston's attorney general and his hand-picked candidate for Chief Justice of the Supreme Court of the Republic of Texas. After his appointment was not confirmed by the senate, Birdsall and Houston became law partners. James W. Paulsen, The Judges of the Supreme Court of the Republic of Texas, 65 TEX. L. REv. 305, 311-13 (1986). A.S. Thurston was nominated by Houston to succeed Birdsall as attorney general; this appointment also was not confirmed. HANDBOOK OF TEXAS, supra note 15 , at 779.

25. The petition, a somewhat stilted model of frontier eloquence, expresses disdain for the "fopperies and quaint conceits" of the canon law, with its "nauseious [sic] and repulsive practice of taking confessions." WRITINGS OF SAM HOUSTON, supra note 10, at 277-78. Since Texas courts were "yet untrammeled and unbound by the fetters of precedent," the judge was urged to "look with indifference to the lumbering tomes of ancient jurisprudence as inapplicable to the unsophisticated administration of justice in a community of republicans." Id. at 278.

26. Id. at 279.

27. Letter from John Birdsall to Sam Houston (May 8, 1838), in Ever ThINE TrULY, supra note 9 , at 25 . 
The new divorce legislation therefore was to be viewed "rather as declaratory of what the law was, than as conferring any new powers upon the Courts." ${ }^{28}$ In short, the gist of the argument was that Sam Houston's divorce was valid because marriage is a civil contract, and judicial authority extends to the performance and breach of contracts. While the legislative branch can set rules to govern marriage contracts, courts are free to act until bound by legislation.

The general proposition supporting the validity of Houston's divorce-that Texas courts had powers in divorce matters not derived from statute-also finds some support in early printed reports. In an 1840 case, the husband complained that the court had, without authority, awarded his wife alimony pending divorce. The Supreme Court of the Republic of Texas rejected his argument, reasoning that temporary alimony was "a practice sanctioned by all the courts of chancery jurisdiction in the civilized world" as well as a right specifically stated in the 1837 Texas divorce statute. ${ }^{29}$ The statute, however, was viewed simply as additional authority, "apart from the rules of equity, which we believe should govern in all such cases." ${ }^{30}$ In a later case, discussing divorce jurisdiction during the period of the Republic, Chief Justice Hemphill commented: "The District Courts have, from a very early period after the organization of the Republic of Texas, granted divorce from the bonds of matrimony. The power may have been, and probably was, exercised prior to 18th December, 1837,"31 the date of the first divorce statute.

The fact that early Texas courts exercised powers to grant divorces, contrary to English common law and without the benefit of legislation, is not evidence of lawless conduct. Rather, the early Texas law of marriage and divorce is best viewed neither as a continuation of English common law, nor as a strict adoption of the Spanish system, but as sui generis. Early Texas courts recognized that "the Common Law is not and never has been in force in this State, on the subject of marital rights." 32

28. Id. The other legal opinion, written by A.S. Thurston, has not survived the years as well. Reading around the missing fragments, however, Thurston agreed that "the power to set aside contracts, is inherent and abides with the judiciary" and that the later act of the Republic Congress "was but confirmatory" of the powers already existing. Letter from A.S. Thurston to Sam Houston (May 22, 1838). Id. at 26 (emphasis in the original).

29. Andrews v. Andrews, Dallam 375, 375-76 (1840).

30. Id. at 376.

31. Sharman v. Sharman, 18 Tex. 521, 523 (1857) (emphasis added).

32. Bradshaw v. Mayfield, 18 Tex. 21, 29 (1856); see also Barkley v. Dumke, 87 S.W. 1147, 1147 (Tex. 1905) ("The provisions of the act with reference to married persons are so inconsistent with the rules of the common law as to show an intention to maintain in reference to marital rights a radically different system."). The truth of such statements is easily demonstrated. The constitution of the Republic of Texas commanded that lawmakers "as early as practicable, introduce, by statute, the common law of England, with such modifications as our circumstances, in their judgment, may require." TEX. CONST. OF 1836, art. IV, $\S 13$ (superseded 1845). While the congress did adopt the common law generally in 1840 , it did so only insofar as the common law was not inconsistent with "Acts of Congress now in force." An Act to Adopt the Common Law of England, To Repeal Certain Mexican Laws, and to Regulate the Marital Rights of Parties $\S 1$ (Jan. 20, 1840), in 1 GAMMEL, supra note 12 , at 177 . Through earlier legislation, courts had been granted broad divorce powers. See generally Cunningham v. Cunningham, 40 S.W.2d 46, 47 (Tex. 1931). Moreover, in the act adopting the common law, the 
While Texas courts ordinarily would look to the Spanish and Mexican law for guidance, ${ }^{33}$ Spanish and Mexican law, in the main, did not recognize divorce. ${ }^{34}$ Thus, with no legal requirement to follow the common law and no guidance from Spanish law, early Texas courts might have viewed their powers as bounded only by a general sense of the equities of the situation.

The specific theory advocated by Houston's lawyers, that marriage is a species of contract, finds some support in judicial opinions of the period, ${ }^{35}$ and would have resonated strongly with the Texas experience. Since few priests authorized to conduct marriage ceremonies could be found in pre-Revolution Texas, some early settlers were tentatively married by written contract or bond. While avoiding one such "bond marriage" on the facts, ${ }^{36}$ which tended to show that the "wife" abandoned a previous husband to take up shipboard residence with the Republic's Secretary of the Navy, ${ }^{37}$ the Texas Supreme Court in 1875 stated:

We think it the duty of the courts, upon the highest considerations of public policy, that the marriages contracted in those times should be regarded as mere civil contracts, and should be sustained as valid whenever the consent of the parties and the intention to enter into the state of matrimony, and to assume its duties and obligations, is clearly shown. ${ }^{38}$

In sum, while Sam Houston's divorce may look like a nullity, if viewed through common-law eyes, the court that granted the divorce undoubtedly believed it had the jurisdiction to do so and to set whatever conditions on the divorce it pleased. In light of the law at the time, the court was probably right.

congress set out numerous regulations regarding the institution of marriage, including adoption of the community property system. An Act to Adopt the Common Law \$ \$ 3-13, in 1 GAMMEL, supra note 12 , at 178-80. The import is clear: Marital rights were not governed by the common law.

33. Courts would, however, deviate from Spanish law under appropriate circumstances. For example, in deciding whether children of slaves should belong to the community or to the separate estate of the mother's owner, the court opted for the comparatively more humane result, dismissing possibly contrary Spanish authority with the comment that "we feel at liberty to maintain the opinion which is conceived to be most in harmony with the rules and the general spirit and policy of Spanish jurisprudence, in relation to the subject matter, and the one which is the best adapted to our own situation and views of sound policy." Cartwright v. Cartwright, 18 Tex. 626, 636 (1857) (emphasis added).

34. See Sharman, 18 Tex. at 523-24.

35. See, e.g., Sapp v. Newsom, 27 Tex. 537, 540 (1864). Courts also recognized, however, that due to the importance of the marriage contract to society, marriage was regulated by the state to an extent not found in other contracts. See, e.g., Moore v. Moore, 22 Tex. 237, 239 (1858).

36. See generally BennetT SMITH, MARRIAGE BY BOND IN Colonial TEXAS (1973); Hans W. Baade, The Form Marriage in Spanish North America, 61 CORNELl L. REV. 1 (1975).

37. The court also may have been influenced by the ostensible husband's notoriety. Before coming to Texas, Colonel Robert Potter served two years in prison for a crime that, in the words of the Texas Supreme Court, was "an offense of an extraordinary nature against two persons, which, throughout the whole Southern States, made him notorious and gave to the newly-coined word 'Potterizing' a terrible significance." Lewis v. Ames, 44 Tex. 319, 343 (1875). While the opinion gives no detail, the story lives in Texas history. Just as Colonel Jim Bowie gave his name to the Bowie knife, Colonel Robert Potter gave his name to what one might do with that knife to discourage another from ever again taking an excessively friendly interest in one's wife. See James R. Norvell, Lewis v. Ames-An Ancient Cause Revisited, 13 Sw. L.J. 301, 308-09 (1959).

38. Lewis, 44 Tex. at 342 (quoting Sapp, 27 Tex. at 540). 


\section{B. Property Division for Ex-Spousal Support}

With one notable exception, ${ }^{39}$ early Texas cases contain no real discussion of permanent alimony. ${ }^{40}$ One possible explanation, and the one usually heard, is that since Texas divorce statutes mentioned only temporary alimony, permanent alimony was implicitly prohibited. The failure of courts to discuss permanent alimony, however, may be due to a number of other factors. First, as members of a nation of hardy and independent immigrants, early Texans often had sufficient separate property to survive after divorce. ${ }^{41}$ Second, given the footloose nature of many settlers, a personal judgment for alimony would often be worth considerably less than the piece of paper upon which it was written. ${ }^{42}$ Third, and perhaps most importantly, Texas adopted the community property system. Since "the chief wealth of the people of Texas consist[ed] in their lands," ${ }^{43}$ creative property division would generally work at least as well as alimony.

The divorce and community property statutes adopted during the Republic of Texas's ten-year lifespan have carried through to modern times with remarkably few changes. ${ }^{44}$ So far as property division was concerned, a divorce court was to

order a division of the estate of the parties in such way as to them shall seem just and right, having due regard to the rights of each party and their children,

39. This exception, Wiley v. Wiley, 33 Tex. 358 (1870), is discussed in detail infra part II.C.

40. One interesting "near-miss" is Wright v. Wright, 6 Tex. 29 (1851), read by an early community property commentator for the apparent conclusion that Texas courts award permanent alimony. See HORACE G. Platt, The Law as to THE PROPERTy Rights of Married Women, As Contained IN THE STATUTES AND DeCisIONS OF California, TEXAS, AND NEVADA $\$ 50$, at 173 (1885). Although appeals in Wright dragged on for so long that support pendente lite may have seemed like permanent alimony to the litigants, and decisions from other jurisdictions dealing with the award of permanent alimony were cited willy-nilly by the Texas Supreme Court, the real issue was the collection of temporary alimony in arrears. Wright, 6 Tex. at 29,32-33. The reporter's headnote, mentioning "permanent alimony ... on separation a mensa et thoro," is misleading.

41. Joseph W. McKnight, Family Law: Husband and Wife, 35 Sw. L.J. 93, 136 (1981). This point was made explicitly by Chief Justice John Hemphill, who noted that "the parties in marriage, in this State, very often have each separate property, and ... very generally there is some community property." Fitts v. Fitts, 14 Tex. 443, 450 (1855). While Chief Justice Hemphill was an astute observer of the times, one tends to think he must have overstated the case somewhat.

42. Consider the case of James W. Robinson, who abandoned a wife and five children in Indiana, moved to Arkansas, remarried (whether he knew prior to remarriage that his wife obtained a divorce in his absence is unclear), moved to Texas shortly before the revolution, then moved again to California during the gold rush of 1849. Robinson was no ne'er-do-well; he was elected governor in the provisional government of the Republic of Texas and served as one of the nation's first judges. See Paulsen, supra note 24 , at 351-54. While many settlers were equally as respectable as those in other areas of the country, a substantial number had left their former homes "with a suddenness explainable only by a desire ... to avoid an appearance as a principal in a court action." WILlIAM RANSOM HOGAN, THE TEXAS REPUBlic 5 (1946).

43. William AleXANDER, Report of the AtTORNey General of the STATE Of TeXas for THE YEAR $1870(1870)$. Immigrants to Texas were attracted primarily by the promise of cheap-or free-land. See generally SIEGEL, supra note 11, at 5-7.

44. Professor McKnight's contribution to this issue is an admirable overview of the development of Texas community property law. Joseph W. McKnight, Texas Community Property Law: Conservative Attitudes, Reluctant Change, 56 LAW \& CONTEMP. PROBS. 71 (Spring 1993). 
if any: provided, however that nothing herein contained shall be construed to compel either party to divest him or herself of the title to real estate or to slaves. $^{45}$

Under this statute, courts were clearly authorized to divide community property as they saw fit. The further question-whether the statute permitted unequal division of community property in favor of a deserving spouse-was early decided in favor of judicial discretion. ${ }^{46}$ A more difficult issue-whether the statute also permitted the division of separate property-was addressed in Fitts v. Fitts. ${ }^{47}$

In her petition for divorce, Nancy Fitts accused her husband Oliver of being "dissolute and dissipated" and of squandering family assets. ${ }^{48}$ As the owner of slaves, land and livestock, Oliver had been a man of some means. Before the marriage, Oliver gave several slaves to Nancy's father, with the income earmarked for Nancy's benefit. ${ }^{49}$ Some time later, Oliver gave the rest of his slaves, his land, and his livestock to Nancy, making all of his assets her separate property. ${ }^{50}$ Therefore, the couple had no community property. ${ }^{51}$ Unwilling to leave Oliver entirely penniless after the divorce, the trial judge ordered that the slaves given to Nancy through the marriage settlement be supervised by a trustee, with some of the income set aside for Oliver's support. ${ }^{52}$ In her appeal to the Texas Supreme Court, Nancy asserted that the Texas property division statute did not permit such a result.

The court's decision by Chief Justice John Hemphill contains a remarkably thorough analysis of a complex question, setting the parameters for Texas courts in property division until the reasoning, and possibly the result, was overruled sub silentio some 120 years later. ${ }^{53}$ Initially, the court noted that each party would presumptively be entitled to his or her separate property, since "[g]enerally there would be no necessity for trenching on the separate property of either partner." ${ }^{4}$ Likewise, an equal split of the community property would ordinarily satisfy the statute's mandate of a "just and right" division. 55 Fitts, however, was not an ordinary case. There was no community property to divide, and the husband had given all his separate property to his wife. Without judicial 484.

45. An Act Concerning Divorce and Alimony $\S 4$ (Jan 6, 1841), in 1 GAMMEL, supra note 12, at

46. Trimble v. Trimble, 15 Tex. 18, 20 (1855) (approving a division of the community estate that allotted approximately two-thirds to the wife, despite a specific argument that the statute mandated equal division).

47. 14 Tex. 443. The issue was not finally resolved, however, until Hailey v. Hailey, 331 S.W.2d 299 (Tex. 1960).

48. Fitts, 14 Tex. at 446.

49. Id.

50. Id. at 446,450 .

51. Id.

52. Id. at 447 .

53. These cases are discussed infra part IV.

54. Fitts, 14 Tex. at 453.

55. Id. 
intervention, then, the husband would have been exposed to "utter destitution, incapable as he is ... of making a support of any kind or degree."56 Even though Oliver was at fault in the breakdown of the marriage, to leave him entirely penniless "would be the extreme of injustice." 57 The Texas Supreme Court therefore dedicated the income from some of Nancy's slaves to Oliver's support. $^{58}$

In reaching this result, the first question addressed by the court was whether one spouse's separate personal property could be awarded to the other on divorce. The statute was not, and still is not, a model of clarity. A court could divide "the estate of the parties" but could not "divest" either party of the title to real estate or, before the Civil War, slaves. ${ }^{59}$ The statute, however, said nothing about separate personal property, an omission Chief Justice Hemphill explained as a probable legislative oversight. When the property division statute was enacted in 1841, only land and slaves were considered by statute to be separate property. Everything else, including personal property, was owned in common. ${ }^{60}$ The legislature therefore probably meant to create a scheme by which all community property, but no separate property, could be divided. When Texas became a state, however, the new constitution and subsequent legislation expanded the definition of separate property to include all property, whether personal or real, owned before marriage, as well as that acquired afterward by gift, devise, or descent. ${ }^{61}$ The Texas Supreme Court therefore faced a dilemma: should it honor the apparent original intent of the legislature and permit only community property to be divided, or should it read the "no divestiture" proviso strictly, with the result that courts could divide anything not specifically protected from divestiture by the statute? Bowing to the equities of the situation, the court opted for a reading that permitted the divestiture of separate personal property. ${ }^{62}$

56. Id.

57. Id.

58. Id. This is a more favorable result than would have been possible had alimony been the court's only option. Until recently, in most jurisdictions, fault generally would bar an award of alimony. See ClARK, supra note $18, \$ 16.1$, at 620 . Texas courts, however, could permit an errant spouse to retain some share of the community property for support purposes, even if that spouse were determined to be at fault. In one case, for example, the husband secured a divorce after proving that his wife tried to poison him. The court nonetheless held that "the wife, although degraded, was entitled to her share of [the community] property and to her own separate property, if any she had," thereby declining to exercise its power to award the wife's half of the community property to the husband. Byrne v. Byrne, 3 Tex. 336, 341 (1848).

59. The proviso prohibiting the divestiture of title to real estate dropped out when Title 1 of the Texas Family Code was enacted in 1969. The Texas Supreme Court, however, has viewed this as a clerical error, rather than a change in the substantive law. See, e.g., Eggemeyer v. Eggemeyer, 554 S.W.2d 137, 139 (Tex. 1977).

60. Fitts, 14 Tex. at 449-50. See An Act Concerning Divorce and Alimony $\$ 4$ (Jan 6, 1841), in 3 GAMMEL, supra note 12 , at 484 .

61. TeX. CONST. OF 1845, art. VII, $\S 19$; An Act Better Defining the Marital Rights of Parties $\S 2$ (March 13, 1848), in 3 GAMMEL, supra note 12 , at 77-78.

62. Fitts, 14 Tex. at 450 . This reading of Fitts is confirmed by Chief Justice Hemphill's discussion of Fitts in Rice v. Rice, 21 Tex. 58, 68-69 (1858). 
The second question-whether placing Nancy's slaves in trust for Oliver's benefit could be considered as "compel[ling] either party to divest him or herself of the title to real estate or to slaves" 63 - was disposed of in short order. Relying, in part, on court decisions interpreting the Kentucky and Alabama statutes on which the Texas legislation was modeled, ${ }^{64}$ holding that life interests in one spouse's property could be decreed to the other on divorce for the purpose of spousal support, the court concluded that "we deem the provision [for a life trust] quite consistent with the Statute, and that it does not infringe the title of the slaves, according to the true intent and meaning of the Act." Under the rule of Fitts, then, courts enjoyed broad discretion to divide separate personalty and to encumber separate realty to assure adequate support after divorce.

\section{The Disappearing Alimony Decision}

Since courts had the power to decree unequal division of the community property, to divest separate personal property, and to do anything short of complete divesture of the owner's title to real estate, the need for alimony rarely arose. Further, because an alimony award was most likely in a case in which neither party had much property, the economics of the situation would make an appeal unlikely if a trial court did award alimony. Wiley $v$. Wiley, ${ }^{66}$ decided by the Texas Supreme Court in 1870, was the exception. The facts of the case, however, do not disprove the thesis that alimony cases ordinarily would not be found in the Texas Supreme Court. To the contrary, the circumstances were extraordinary. In the period immediately following the Civil War, the value of Texas land was very depressed, ${ }^{67}$ making a property award less likely than usual to meet the needs of a deserving spouse. Moreover, the trial court failed to award attorney's fees to the prevailing party; ${ }^{68}$ her counsel was thus given an additional incentive to appeal. The Texas Supreme Court's opinion, however, sunk like a stone into the waters of Texas jurisprudence, with nary a ripple of subsequent citation to mark its passing.

In Wiley, ${ }^{69}$ the husband initiated suit, charging his wife with "cruel treatment of his small children by her last predecessor [he had survived two prior wives], and with adultery-elaborating the allegations with a good deal of detail and, 484.

63. An Act Concerning Divorce and Alimony $\$ 4$ (Jan 6, 1841), in 1 GAMMEL, supra note 12, at

64. Fitts, 14 Tex. at 450 .

65. Id. at 453 .

66. 33 Tex. $358(1870)$.

67. Immediately after the Civil War, the value of Texas land fell to less than $20 \%$ of its pre-war value. ERNEST WALLACE, TEXAS IN TURMOIL 229 (1965). Courts, of course, were cognizant of this fact. In 1868, citing "the financial situation of the country and the superabundance of wild land," the Texas Supreme Court refused to order the sale of real estate in a divorce case. Craig v. Craig, 31 Tex. 203, 204 (1868).

68. Wiley, 33 Tex. at 360 .

69. Id. at 358 . 
apparently, with much gusto."70 Mr. Wiley failed to prove his claims, and his wife's cross-bill for divorce was granted. The trial court evidently wished to make some provision for Mrs. Wiley, who "had nothing when she married [him], and was equally destitute when driven from him."11 Unfortunately, as explained in the reporter's summary of the facts, the couple had more debts than property. ${ }^{72}$ The trial court therefore gave the wife "alimony" in the sum of fifty dollars a year for twelve years, but denied attorney's fees. ${ }^{73}$ As a result, Mrs. Wiley's lawyer took the case to the supreme court, seeking an increase in the amount of alimony and a judgment for attorney's fees. ${ }^{74}$ The Texas Supreme Court obliged, increasing payments to one hundred dollars a year for life, awarding one hundred dollars in legal fees, and prohibiting the husband from disposing of property to avoid payment. ${ }^{75}$ Under any fair reading of the opinion, Wiley is an explicit award by the Texas Supreme Court of permanent alimony; it appears to be the first direct ruling on the subject in Texas jurisprudence. Nonetheless, the decision has never once been cited by any Texas court for any conclusion, much less discussed or distinguished in the course of any decision holding that permanent alimony is contrary to Texas public policy.

How can a Texas Supreme Court decision awarding permanent alimony simply be ignored in later decisions proclaiming alimony to be contrary to the basic public policy of the state? One possibility is that Wiley v. Wiley was ignored because of the court that issued the decision. In 1870, Texas was in the throes of Radical Reconstruction. The popularly elected and unabashedly exConfederate supreme court had been removed from the bench and replaced by a panel of military appointees. ${ }^{76}$ This "carpetbagger" military court has never been considered a "real" Texas Supreme Court, and its decisions are considered to have no precedential value. ${ }^{77}$ As a product of this military tribunal, Wiley may have simply been ignored.

There are, however, several problems with this ad hominem theory. First, even if the Wiley decision were considered "bad law" because of its authorship, one would expect later courts at least to mention the case, if only for the pleasure of ridiculing the result. Second, even if the court that decided Wiley was staffed by military appointees, the author of the opinion, Chief Justice

70. Id. at 359. The supreme court commented that "we have seldom heard more serious charges preferred against a woman," and that "it is difficult to imagine any thing more disreputable." Id. at 362. The court did not elaborate, and the briefs have long since disappeared, leaving a clear field for the exercise of one's imagination.

71. Id. at 359 .

72. Id.

73. Id.

74. Id. at 360.

75. Id. at 362 .

76. See generally James R. Norvell, Oran M. Roberts and the Semicolon Court, 37 TEX. L. REV. 279 (1959); George E. Shelley, The Semicolon Court of Texas, 48 Sw. HisT. Q. 449 (1945).

77. Shelley, supra note 76, at 467; see also Peck v. San Antonio, 51 Tex. 490, 492 (1879); Jim Paulsen \& James Hambleton, Confederates and Carpetbaggers: The Precedential Value of Decisions From the Civil War and Reconstruction Era, 51 TEX. B. J. 916 (1988). 
Morrill, was a Texan of long standing and a respected jurist. ${ }^{78}$ In addition, alimony is hardly the sort of politically charged issue on which a Reconstruction court's views might be suspect. Third, the wife's counsel, S. P. Donley, had impeccable credentials, both as an attorney and as an unreconstructed Confederate. He was, in fact, one of the very judges removed from the high bench by the military authorities. ${ }^{79}$ If the authority of Texas courts to award permanent alimony were in doubt, it is inconceivable that Donley, having received a generally favorable decision at the trial level, would have exposed it to reversal by taking an appeal to the very panel that replaced him on the Texas Supreme Court.

A different, and more plausible, explanation for the disappearance of the Wiley decision into the dustbin of Texas legal history combines the consequences of ignorance and mistake. Wiley was decided before the ascendency of West Publishing Company and its digests. ${ }^{80}$ The closest thing to a Texas case digest in the 1870 s was published by George Washington Paschal, who did most of his work in Austin while under virtual house arrest as a Union sympathizer during the Civil War. ${ }^{81}$ Unfortunately, Wiley appeared in print just a little too late to receive proper treatment in Paschal's 1872 digest. ${ }^{82}$ The decision was reported accurately in Myer's 1881 digest, ${ }^{83}$ but since Myer was not a Texas attorney, Paschal's work undoubtedly had the wider circulation. By 1901, when Ocie Speer published his landmark Treatise on the Law of Married Women in Texas, ${ }^{84}$ the damage was done: Texas courts, apparently ignorant of Wiley, had already declared that alimony was contrary to the public policy of the state. ${ }^{85}$

78. Chief Justice Amos Morrill, born in Massachusetts, had practiced law in Texas since 1838. After his service on the Texas Supreme Court, he was United States District Judge for the Eastern District of Texas, resigning a short time before his death in 1884 . While a Unionist, Morrill was far from being a "carpetbagger." See generally 2 HANDBOOK OF TEXAS, supra note 15, at 237.

79. Stockton P. Donley received his legal education in Kentucky and emigrated to Texas in 1846. He served as a lieutenant in the Confederate Army. After his brief post-war service on the Texas Supreme Court, he became the law partner of Oran M. Roberts, who later served as chief justice and state governor. See id. at 513.

80. Coverage of Texas cases in West's South Western Reporter began in 1886, sixteen years after the Wiley decision.

81. Id. at 343 .

82. Paschal's three volume digest was published one volume at a time, between 1872 and 1875 . While the first volume, including the topic of "Alimony," was published in 1872, it included annotations only through Volume 31 of Texas Reports. See 2 GEORGE WASHINGTON PASCHAL, A DIGEST OF DECISIONS: COMPRISING DECISIONS OF THE SUPREME COURTS OF TEXAS AND OF THE UNITED STATES UPON TEXAS LAW, OF ForCE AND REPEALED iii (W.H. \& O.H. Morrison 1874). The second volume, published in 1874, extended coverage through Volume 33, and Wiley $v$. Wiley was digested under the topic of "Divorce." See id. at iii, 846. The digest note, however, focuses on procedural aspects of the case, that is, the judicial power to increase an award of alimony on appeal, and gives no hint that the Texas Supreme Court in Wiley actually affirmed an award of permanent alimony. Id. at 846 . Rather, Paschal misleadingly placed his discussion of Wiley under a general digest heading for "alimony pending the suit." Id. Judging from the general scheme of Paschal's work, the substantive aspect of Wiley-that is, the award of permanent alimony-would most likely have been treated in the first volume.

83. WILliam G. MYER, A DIGEST OF THE TEXAS REPORTS 350 (W.J. Gilbert, 1881).

84. OCIE SPEer, A Treatise ON THE LAW Of MARRIEd Women IN TEXas (1901).

85. These cases are discussed infra part III.A.1. 
Speer's treatise made matters worse. The first edition mentioned Wiley and was published in time to have had some possible effect on the development of the law. Unfortunately, Speer misread Wiley. To Ocie Speer, Wiley proved only that "[a] court may sometimes make an order for the payment to the wife of money[,] more as a settlement of property rights than as alimony in its strict sense." $" 86$

Ocie Speer's interpretation of Wiley, while not impossible, is highly implausible. Speer's reading - that the award of one hundred dollars a year to the wife is just an odd form of property division-is supported by the fact that the body of the opinion does not contain the word "alimony," that the husband was restrained from selling his property to avoid payment, and by the court's command that "the decree relative to the division of the property be reversed." 87 Against this, however, one must balance the fact that the reporter's headnotes, the summary of facts, and the closing decretal sentence all call the award "alimony." 88 Moreover, the summary of the prevailing counsel's argument contains references to ten decisions from other jurisdictions dealing with spousal maintenance or alimony. ${ }^{89}$ When one considers the fact that the Texas Supreme Court had just fired one reporter of decisions because he had embellished opinions with unnecessary material, ${ }^{90}$ it is reasonable to assume that the new reporter's headnotes and summary were prepared with more than usual attention to accuracy and relevance. Finally, at least three other commentators have read Wiley in its most obvious sense, as an award of permanent alimony. ${ }^{11}$ Speer's misreading is unfortunate, not only because his treatise became an instant classic, ${ }^{92}$ but also because Speer, who soon became a judge, wrote his error into Texas law in an early "no permanent alimony" opinion. ${ }^{93}$

86. SPEER, supra note 84 , at 421 .

87. Wiley, 33 Tex. at 362 .

88. Id. at $358,359,362$.

89. Id. at 360-61.

90. See Preface, 31 Tex. i, vii-viii (1870).

91. Myer, for example, stated that in Wiley the supreme court "reformed [the decree] as to alimony, increasing the allowance from fifty dollars to one hundred dollars per annum, enjoined the husband from disposing of his property so as to defeat the same, and remanded the cause to the district court for the enforcement of the decree." MYER, supra note 83, at 350 . An interesting citator, published by one current and one ex-judge of the district bench the year after Speer's treatise appeared, collected and contrasted summaries of "conflicting" cases. 2 W. W. KING \& S. J. BROOKS, CONFLICTING CIVIL CASES IN THE TEXAS REPORTS (1902). Wiley was described as an award of alimony and contrasted with Pape v. Pape, 35 S.W. 479 (Tex. Civ. App.-San Antonio 1896, writ dism'd), the first Texas "no alimony" case. Id. at 481 . The authors used a "contra" notation, signifying that "a contrary doctrine is announced in a subsequent case without reference to the preceding case." $1 \mathrm{~W}$. W. KING, CONFLICTING CIVIL CASES IN THE TEXAS REPORTS 17 (1890). In 1931, thirty years after Speer's treatise was first published, the encyclopedic Texas Jurisprudence listed Wiley as a "but see" contrast to the line of Texas "no alimony" cases, with no attempt to explain it away as just an extreme example of property division. 15 TEX. JUR. Divorce and Separation $\$ 153$ n.17 (1931).

92. Citations to Speer's work appear in Texas Supreme Court summaries of argument as early as 1903, and frequently thereafter. See, e.g., Nolan v. Moore, 72 S.W. 583 (1903).

93. See Bond v. Bond, 90 S.W. 1128 (Tex. Civ. App.-Fort Worth 1905, no writ). 
Assuming that Wiley is exactly what it appears to be-a pure permanent alimony case-a question remains: On what basis did the court grant permanent alimony? The opinion offers no help whatsoever, as it is little more than a brief recital of facts and a pronouncement of judgment. While the original briefs cannot be found in court archives today, the reporter's abbreviated synopsis of Mrs. Wiley's lawyer's "learned and elaborate argument" 94 does offer a clue. The list of authorities and legal principles contains a Kentucky case, Lockridge $v$. Lockridge, ${ }^{95}$ cited for the proposition that "[c]ourts of chancery in this country, like ecclesiastical courts in England, grant divorces a vinculo, and decree alimony to a wife cruelly treated by her husband." 96 Lockridge is the citation most closely on point on the alimony issue and the only alimony decision cited twice in the synopsis of argument. Moreover, Mrs. Wiley's counsel received his legal education in Kentucky. ${ }^{97}$

Mrs. Wiley's use of Lockridge may provide a key to the unstated rationale for the Wiley decision. At the time Wiley was decided, Bishop's treatise ${ }^{98}$ was the preeminent authority on divorce law in the United States. In the edition current at the time of the Wiley decision, Bishop described a minority rule with respect to alimony that allowed courts to grant alimony in a separate action, one independent of a suit for divorce or permanent separation. ${ }^{99}$ While Bishop criticized cases like Lockridge as "exceptions to the general rule, and departures likewise from principle," 100 he admitted that there was "some strength of argument and some apparent authority in favor of the jurisdiction."101

These minority rule cases are probably best understood as granting alimony in cases where a permanent separation would have been proper, rather than in a suit for absolute divorce such as Wiley. ${ }^{102}$ The reporter's summary of argument in Wiley contains an error, however, indicating that the Texas Supreme Court may not have been alerted to this nuance. In Lockridge, the Kentucky Supreme Court actually stated that courts could grant divorces a mensa et thoro without statutory authority, not divorces a vinculo, as stated in the Wiley

94. Wiley, 33 Tex. at 360 .

95. 33 Ky. (3 Dana) 28 (1835).

96. Wiley, 33 Tex. at 361.

97. See supra note 79.

98. JOEL PRENTISS BISHOP, COMMENTARIES ON THE LAW OF MARRIAGE AND DivORCE (4th ed. 1864).

99. Id. $\S 354-56$, at 283-86 (citing decisions from Kentucky, Maryland, Virginia, North Carolina, South Carolina, and Alabama).

100. Id. § 356, at 286 .

101. Id.

102. The discussion occurs in Bishop's treatise in the chapter entitled Alimony Without Divorce. Citing a number of more recent cases from some of the same jurisdictions, Clark likewise concludes that "these cases are probably limited to alimony in actions for separation rather than absolute divorce," adding, "In any event, they are based upon a mistaken reading of English legal history." CLARK, supra note $18, \S 16.1$, at 620 . 
summary. ${ }^{103}$ Since the difference is that between permanent separation and true divorce, the error is material. ${ }^{104}$

The fact that the Texas Supreme Court may have been misled by a mistaken statement of the Kentucky rule does not necessarily mean that the Wiley result is in any sense "wrong." As already discussed, Texas courts had considerably more theoretical discretion in dealing with matters of divorce than did their common law counterparts, and the court in Wiley probably knew this. ${ }^{105}$ If courts in some other jurisdictions felt at liberty to grant alimony without a pending divorce suit, it is not a large step to conclude that Texas courts could grant alimony in connection with a divorce, since there was no statute to the contrary. In Wiley, the Texas Supreme Court evidently took that step.

III

ALIMONY IN EVERYTHING BUT NAME (1876-1969)

Since the community property system, statutes, and case law of early Texas were not intrinsically hostile to the concept of postdivorce spousal support ${ }^{106}$ another source for the modern-day Texas ban on alimony must be sought. This

103. More precisely, the Kentucky court stated: “Adopting the civil law, in this particular, the Ecclesiastical Courts of England, and the Chancery Courts of this country have, not infrequently, granted divorces a mensa et thoro, and secured alimony to wives whose husbands had treated them barbarously or cruelly." Lockridge, $33 \mathrm{Ky}$. (3 Dana) at 28.

104. A more typical application of similar authority can be found in Galland v. Galland, $38 \mathrm{Cal} .265$ (1869), a California case decided one year before Wiley. A state statute provided for temporary alimony pending divorce, and permanent alimony following divorce. Id. at 274 (Sprague, J., dissenting). Mrs. Galland, who had been driven from her home by her husband, sought a court order for support but not a permanent divorce. A vigorous dissenting opinion argued that since the California legislature provided for alimony only in the context of divorce, the maxim expressio unius est exclusio alterius prohibited the award of alimony unless a divorce action were pending. Id. at 275.

The California Supreme Court, however, upheld Mrs. Galland's right to support. The majority opinion criticized English common law doctrines limiting the rights of married women, concluding that a "system so utterly inconsistent with a just and enlightened view of the marriage relation could not long withstand the advancing march of civilization." Id. at 266 . The court cited Kentucky authority for the power of a court of equity to grant alimony without a pending divorce suit, $i d$. at 268 , and rejected application of the expressio unius doctrine, reasoning that the statute dealt only with the subject of alimony in the context of divorce, id. at 267-68, leaving courts otherwise free to act.

105. In George v. Stevens, 31 Tex. 670 (1869), a debtor-creditor case decided one year prior to Wiley, Chief Justice Morrill left little doubt about his lack of regard for the common law in the field of marital rights.

When the congress of the republic of Texas, through the influence of a disciple of Coke, passed an act introducing the common law of England to be the rule of decision of the republic, it was fortunate for the female branch of the human family, that there were in that legislative assembly those who were unwilling that wives should occupy the station assigned them by the common law of England. So discordant is the common law of England with the statute declaring marital rights . . . that a system of jurisprudence based upon a mixture of these incongruities cannot be otherwise than discrepant and incongruous.

Id. at 673-74.

106. Some interesting support for the view that early Texas law was not adverse to permanent alimony is found in Platt's 1885 comparative treatise on married women's property rights in California, Texas, and Nevada. A fair reading of Platt's subsection on Texas alimony leaves the clear impression that permanent alimony was available under Texas law at the time. See PLATT, supra note 40 , $\S 50$, at 171-73. 
section suggests that the real source is a series of turn-of-the-century decisions applying strict common law principles in apparent ignorance of earlier precedent. The nature of the legal developments during this middle period of Texas law make it difficult to focus on a few paradigmatic cases. Texas courts rejected the possibility of permanent alimony by indirection, through dicta in a series of appellate decisions spanning more than thirty years, though never in a square holding by the Texas Supreme Court. Trial courts compensated for the lack of ability to grant alimony by gradually developing a variety of property division devices, some of which seemed very much like alimony. In addition, in 1967, when the Texas Supreme Court first declared unequivocally, though mistakenly, that alimony was already contrary to the state's public policy, ${ }^{107}$ what the court actually meant to say can be understood only by viewing its language in the context of earlier decisions.

\section{A. The Birth of the "No Permanent Alimony" Doctrine}

1. Alimony and Legislative Policy. Working backward through strings of citations to the earliest judicial articulation of the "no permanent alimony" doctrine, one finds that all threads converge in Pape v. Pape, ${ }^{108}$ an 1896 Court of Civil Appeals case. In Pape, the court's reasons for refusing to permit permanent alimony are set out clearly. First, following the general common law rule, the court decided that permanent alimony required specific statutory authority, ${ }^{109}$ while Texas statutes provided only for temporary alimony. ${ }^{10}$ Moreover, the court believed that "[a]mple provision [was] made in the statutes of this state for the support of the wife by the provision for the division of the property."111 The court explained that proper support could be assured, as in Fitts, ${ }^{112}$ by placing separate property in trust, with income designated for the support of husband, wife, or children. ${ }^{113}$

The reasoning employed in Pape is not particularly surprising, at least if one assumes that the appeals court was wholly ignorant of Wiley and other early Texas authority to the contrary. Two aspects of the Pape decision, however, are remarkable. First, Pape is not an alimony case at all. Since the case involved only child support, incorrectly termed "alimony" by the parties, ${ }^{114}$ all discussion of alimony is dicta. Second, despite the fact that Mrs. Pape was granted a divorce because of her husband's cruelty (a finding that was not challenged) the court showed, no sympathy whatever for the plight of the wife and children.

107. Francis v. Francis, 412 S.W.2d 29 (Tex. 1967).

108. 35 S.W. 479 (Tex. Civ. App.-San Antonio 1896, writ dism'd).

109. Id. at 480 . This holding was perfectly in line with then-current scholarly authority on the subject. See, e.g., 2 Joel PRENTISS BISHOP, NEW COMMENTARIES ON MARRIAGE, DIVORCE AND SEPARATION \& 857 (Chicago: T. H. Flood \& Co. 1891).

110. Pape, 35 S.W. at 480 .

111. Id.

112. See supra discussion accompanying notes $48-65$.

113. Pape, 35 S.W. at 480.

114. Id. 
Instead, the trial court's decision on custody and child support was criticized as depriving the husband of "the consolation and comfort of the society of his children" and "practically plac[ing] him in a state of serfdom."115

For a full thirty-five years after Pape, the Texas Supreme Court did not speak to the question of permanent alimony. ${ }^{116}$ During this time, a succession of appeals court cases dealing almost exclusively with child support ${ }^{117}$ followed Pape. The reasoning of Pape seemed unassailable, even to such a confirmed advocate of women's rights as Ocie Speer. ${ }^{118}$ As an appellate judge, Speer reversed a judgment of five dollars a month for the support of a minor child, based in part on his conclusion that "[t]here is no such thing in this state as permanent alimony." 119 In 1927, however, in Cunningham v. Cunningham, ${ }^{120}$ the Fort Worth Court of Appeals decided "respectfully [to] differ from the opinion of [other] eminent judges"121 and to authorize the award of periodic child support payments. The ruling was calculated to catch the Texas Supreme Court's attention, and it did.

The Texas Supreme Court's decision in Cunningham was four years in the making. When the opinion finally issued, the high court's conclusion that periodic child support payments were not authorized by statute was accompanied by a statement that the court had "no doubt of the power of the Legislature to so amend our statutes as to empower the courts to decree and compel the

115. Id. at 481 . The opinion paints a highly sympathetic portrait of the husband, describing him as "a farmer in poor circumstances, with no means of support but what might possibly come out of his labor upon a rocky, unproductive mountain farm." Id. at 480-81. The court gave practical effect to its sympathy for the husband, at the expense of the former wife and the couple's seven children, by reforming the judgment to eliminate any award for child support. A remand, of course, would have permitted the trial court to follow Fitts and create a trust for the children's support. Id.

116. The fact that it took the Texas Supreme Court so many years to address the issue is explained, at least in part, by the high court's jurisdiction. When the Texas legislature created intermediate appeals courts in 1891, it made their jurisdiction final, with certain exceptions, in divorce cases. An Act to Organize the Courts of Civil Appeals $\$$ 5(3) (April 13, 1892), in 10 GAMMEL, supra note 12, at 390; see also generally James P. Hart, The Appellate Jurisdiction of the Supreme Court of Texas, 29 TEX. L. REV. 285, 307-09 (1951). One such exception permitted the Texas Supreme Court to resolve conflicts between different courts of appeals. Thus, as long as courts uniformly refused to permit personal judgments for periodic support payments, a pronouncement from the supreme court was unlikely.

117. See, e.g., Bond v. Bond, 90 S.W. 1128 (Tex. Civ. App.-Fort Worth 1905, no writ); Ex parte Gerrish, 57 S.W. 1123 (Tex. Crim. App. 1900); Boyd v. Boyd, 54 S.W. 380 (Tex. Civ. App.-Dallas 1899, no writ); Ex parte Ellis, 40 S.W. 275 (Tex. Crim. App. 1897). The Boyd case is an exception-there was no child, but the wife claimed to be pregnant and sued for permanent alimony. Boyd, 54 S.W. at 380 . The wife's pleadings for alimony were struck by the trial court and, since she did not amend her pleadings, the Court of Civil Appeals deemed this sufficient reason to deny alimony. Id. at 381 .

118. The father of five daughters, Speer held very liberal views on women's issues. Note, Ocie Speer, 67 Years at the Bar, 22 TEX. B. J. 517, 553 (1957). In 1913, while serving on the Court of Civil appeals, Judge Speer drafted legislation intended to give women full rights to own and manage property, to make contracts, and to enter into business dealings. Hortense Ward, Shall Women Have Adequate Laws?, 7 TEX. MAG. 239, 241 (1913). This seems to have been the bill that Governor Colquitt threatened to veto, leading to the passage of a more restrictive law. See Joseph W. McKnight, Texas Community Property Law-Its Course of Development and Reform, 8 CAL. W. L. REV. 117, 125 n.45 (1971).

119. Bond, 90 S.W. at 1128.

120. Cunningham v. Cunningham, 299 S.W. 483 (Tex. Civ. App.-Fort Worth 1927), rev'd, 40 S. W.2d 46 (Tex. 1931).

121. Id. at 487 . 
payment of allowances for the support of dependent minors as against a parent." 122 The legislature took the hint and passed Texas's first child support statute in $1935 .^{123}$

The Cunningham decision was obviously intended to be a major pronouncement on the subject of marital rights. ${ }^{124}$ While some of the reasoning is obscure, a few major points come through quite clearly. First, the court suggested that postdivorce support was rejected by implication when the 1837 divorce statute was superseded by the legislation of 1841 . Quoting the text of the 1837 statute, the Texas Supreme Court concluded that "it was originally the public policy of the Republic to confer authority on the district court to compel either spouse to provide the other with proper maintenance." 125 The court observed that the language of the 1841 divorce act provided for spousal maintenance only during the pendency of divorce actions, and concluded that this new legislation evidenced "a change in the public policy of the Republic."126

122. Cunningham, 40 S.W.2d at 51.

123. Legislation to undo the Cunningham result was proposed in 1933, see S.J. of Tex., 43d Leg., Reg. Sess. 1280 (1933), and passed in 1935. It has been suggested that the fact that the statute provided only for child support somehow constitutes legislative intent not to permit permanent alimony. See, e.g., McElreath v. McElreath, 345 S.W.2d 772, 750 (1961) (Griffin, J., dissenting on rehearing); Daryl B. Crown, Note, Divorce-Contractual Alimony-A Contractual Obligation for Support After Divorce Executed by the Parties and Approved by the Court is Not Permanent Alimony, 46 TEX. L. REV. 391,394 n.20 (1968). Since the Cunningham case involved only child support, however, this theory seems to stretch the negative implication of legislative intent too far.

124. This conclusion is borne out by an examination of the Cunningham records. By the time Cunningham came to the Texas Supreme Court, Ocie Speer was sitting on Section B of the Texas Commission of Appeals, one of two three-person panels created to aid the court in the disposition of its cases. He wrote an opinion of modest length, reversing the decision of the court of appeals on much the same substantive grounds as those ultimately relied upon by the Texas Supreme Court. This opinion is marked "withdrawn," indicating that it did not meet with the high court's approval. Opinion No. 10215006, in case records for No. 5006, Cunningham v. Cunningham (Texas State Archives, Austin).

125. Id. at 47 .

126. Id. While discerning legislative intent is a somewhat whimsical exercise at the best of times, the Cunningham court's confident discussion of the intent of Republic of Texas lawmakers in 1841 is a bit more whimsical than most such efforts. The 1841 legislature was, after all, the same session in which Sam Houston was attacked with a hand axe during excessively vigorous debate over the Cherokee Land Bill, and in which legislation to prevent "tippling" (defined as consuming more than one gallon of hard liquor in a single sitting) was voted down amid "much hilarous debate." SEYMOUR V. CONNOR, ADVENTURE IN GLORY 145-46 (1965).

The court in Cunningham appears to have read the first Texas divorce act as providing for postdivorce maintenance, and the second act's provision for maintenance pending divorce as changing that "public policy." 40 S.W.2d at 47. The first act's statement that courts could "decree divorces as well from the bonds of matrimony as from bed and board, or for a separate maintenance" could also be read as merely differentiating between actions for separate maintenances and divorces from bed and board. The two are viewed in law as distinct. See, e.g., Stephenson v. Stephenson, 298 S.W.2d 717, 719 (Tex. 1957) ("The prayer in a suit for separate maintenance is never a prayer for divorce, either a vinculo or mensa et thoro."). Elimination of provisions for separate maintenance or for divorce from bed and board could be read simply as a preference for absolute divorce. This would be in line with Bishop's condemnation of divorce from bed and board as "that excrescence, that carbuncle on the face of civilized society, that demoralizing mock-remedy for matrimonial ills." BISHOP, supra note 98, § 277, at 217-18. In any event, given the conclusion of the Texas Supreme Court in Andrews v. Andrews, Dallam 375 , 375-76 (1840), that the 1837 statute simply confirmed the courts' inherent powers, a decision evidently not considered by the Cunningham court, it is difficult to derive any certain conclusion from the 1841 legislation. 
Second, the court emphasized the broad authority given to courts in matters of property division, and the propriety of using that authority for the support of spouses and children. ${ }^{127}$ Third, the court noted that fathers were still liable for the support of their children under the "necessaries" doctrine, that is, that merchants could sell goods on credit to the children or their mother and collect from the husband if the goods were "necessary" for the children. ${ }^{128}$ Finally, the court concluded that permanent alimony was not permitted without specific statutory authorization. ${ }^{129}$

Two aspects of the Cunningham opinion deserve special attention. First, while Cunningham is often credited as the source of the "mysterious, unarticulated"130 doctrine that alimony is contrary to public policy in Texas, ${ }^{131}$ the decision actually says nothing of the sort. The Texas Supreme Court simply concluded that no Texas statute then explicitly provided for permanent alimony-a statement that says a great deal about jurisdiction, but very little about public policy. The 1953 decision of McBride $v$. McBride ${ }^{132}$ seems to be the first case to take the analysis a step further, reading Cunningham for the broader proposition that permanent alimony is "against public policy." The holding of $M c B r i d e$-refusing to recognize contractual alimony-was overruled fourteen years later. ${ }^{133}$ Nonetheless, the courts of civil appeals' mistaken rhetoric in McBride has taken on a life of its own, with a number of Texas decisions now imitating the McBride court's mistake of citing Cunningham for a conclusion the supreme court simply did not reach. ${ }^{134}$

The second interesting aspect of the Cunningham decision is that the result was not inevitable, even if one assumes the court were writing on a clean slate, bound only by its view of the statutes. If the court in Cunningham had looked to the law in other community property states for guidance, ${ }^{135}$ it might have reached a different result. The court's conclusion that alimony requires statutory authority is contrary to the reasoning of the California Supreme Court in Galland v. Galland, which had found alimony available in equity, even without

127. Cunningham, 40 S.W.2d at 48.

128. Id.

129. Id. at $49-51$.

130. John J. Sampson, Interstate Spouses, Interstate Property, and Divorce, 13 TEX. TECH L. REV. 1285, 1325 (1982).

131. See, e.g., Eichelberger v. Eichelberger, 582 S.W.2d 395, 402 (Tex. 1979); McElreath v. McElreath, 345 S.W.2d 722, 747 n.2 (Tex. 1961) (on rehearing).

132. McBride v. McBride, 256 S.W.2d 250, 254 (Tex. Civ. App.-Austin 1953, no writ).

133. The conclusion in $M c B r i d e$, that a voluntary contract for alimony is void as against public policy, has been overruled specifically and McBride "disapproved." Francis v. Francis, 412 S.W.2d 29, 33 (Tex. 1967).

134. See, e.g., Eichelberger, 582 S.W.2d at 402; Francis, 412 S.W.2d at 32.

135. While in Cunningham the Texas Supreme Court cited some out-of-state authority, that authority was limited to common law jurisdictions. See, e.g., Cunningham, 40 S.W.2d at 51 (citing decisions from Alabama, Georgia, Michigan, and Missouri). This preference for common law authority may not be accidental. In a roughly contemporaneous case dealing with spousal support during marriage, the Texas Commission of Appeals, in an opinion adopted by the Texas Supreme Court, referred disparagingly to "Spanish law, which for a period at least exerted some influence upon our jurisprudence." Gonzales v. Gonzales, 300 S.W. 20, 21 (Tex. 1927). 
a pending suit for divorce. ${ }^{136}$ Washington law would have provided an even more interesting parallel. Since territorial days, Washington courts awarded alimony in appropriate cases. ${ }^{137}$ In a 1901 decision, ${ }^{138}$ using reasoning very similar to that employed in Cunningham ${ }^{139}$ and construing a virtually identical statute, ${ }^{140}$ the Washington Supreme Court decided it had statutory authority to award periodic payments to the wife, "call it alimony or whatever name you will." 141 Neither the California nor the Washington option was approved, or apparently even considered, by the Cunningham court, and the reasoning of the Cunningham decision has not been challenged since.

\section{Breach of Marital Contract. While Cunningham was the Texas Supreme} Court's first, and still remains the most important, pronouncement against permanent alimony, the real focus of the case was child support. Another case, decided by the Texas Commission of Appeals a few years before Cunningham, adds a valuable dimension to the discussion, as it dealt directly with the rights of a wife. In Gowin v. Gowin, ${ }^{142}$ a husband was not supporting his wife in the manner he had promised before marriage. Mrs. Gowin did not want a divorce; she simply wanted her husband to honor his premarital promises. As Mrs. Gowin's lawyer, Ocie Speer-who was between judicial appointments at the time-sued for breach of contract. The question, as presented by the commis-

136. 38 Cal. 265, 268 (1869). See also note 104. The California court rejected the "necessaries" doctrine to which the wife and children were reduced by the Cunningham decision, reasoning that " $[t]$ ] purchasing from others, on the husband's credit, the necessaries for her support, affords, at best, a most humiliating, unreliable and precarious means of subsistence." Id. at 266. The California court also rejected the argument accepted by the Texas court-that only the legislature can deal with alimony-by reasoning that even if legislation sets out the limits of alimony in suits for divorce, courts are free to award alimony outside the context of divorces. Id. at 267. The Cunningham court could have employed similar reasoning, reading the pendente lite statute as governing procedure during divorce cases, but not controlling the substance of a final decree. The specific holding of the California court, however, was probably foreclosed in Texas by an 1886 opinion, holding that an abandoned wife had no right to judicially-mandated support, in the absence of a suit for divorce. Trevino v. Trevino, 63 Tex. 650,651 (1885). This five-sentence opinion, however, is ambiguous, in holding that a wife not seeking a divorce had no support remedy "at least in this form of action," but that if she were seeking a divorce "her remedy would be complete," whatever that means. Id. This case was cited in Cunningham, 40 S.W.2d at 49. Of course, whatever the meaning of the Trevino opinion, the result is contrary to the line of authority cited to the Texas Supreme Court in Wiley. See discussion supra part II.C.

137. A survey of Washington law is contained in Loomis v. Loomis, 288 P.2d 235 (Wash. 1955).

138. In re Cave, 66 P. 425 (Wash. 1901).

139. The Washington court, like the Texas Supreme Court, acknowledged that the authority to award alimony is derived from statute and that, since Washington statutes (as in Texas) provided only for temporary alimony, permanent alimony might be excluded by implication. Compare Cave, 66 P. at 42627, with Cunningham, 40 S.W.2d at 47-48.

140. The Washington statute, using language almost identical to its Texas counterpart, provided that "[i]n granting a divorce, the court shall also make such disposition of the property of the parties as shall appear just and equitable." Cave, 66 P. at 427; see also Cunningham, 40 S.W.2d at 47. This grant of wide discretion appeared to the Washington court to be more indicative of the trial court's power on final divorce than did the implications that could have been drawn from the Washington pendente lite statute. See Cave, 66 P. at 427.

141. Cave, 66 P. at 427.

142. 292 S.W. 211 (Tex. Comm'n App. 1927, judgm't. affd). 
sion of appeals, was: "Does breach of the marital obligations by one spouse give rise to a justiciable right in the other of such nature as that the one may sue for, and recover, damages from the other as for breach of a contract, in the absence of a divorce or prayer therefor?"143 Both the Fort Worth Court of Civil Appeals and the Texas Commission of Appeals answered the question in the negative. Both courts rejected the view of marriage as a mere contract, ${ }^{144}$ grounding their conclusion, at least in part, on the interspousal immunity doctrine that prohibited one spouse from suing another for personal injuries. ${ }^{145}$ More to the point for purposes of historical analysis, both courts explained at length some of the philosophy and public policy undergirding their holdings.

In the Court of Civil Appeals, there was a split of opinion regarding Mrs. Gowin's right to sue. After reciting the purely legal arguments against allowing a breach of contract action in this instance, the majority of the court concluded that "to hold that a cause of action, such as here asserted, can be maintained in the courts of the country, would endanger the institution of marriage, and would therefore be against public policy." 146 Granting Mrs. Gowin a cause of action, the court reasoned, "would furnish an added incentive to sue for such damages in a suit like the present suit, and also to sue for a divorce and recover such damages in that suit and on the same grounds for which a divorce is sought."147

In a lengthy dissenting opinion, Chief Justice Conner, Speer's former colleague on the Fort Worth bench, wrote a carefully reasoned and remarkably "modern" defense of women's rights. Noting that "the question [of proper marital support] is of great importance to every woman who is, or may become, a wife or mother - a highly cherished portion of our people,"148 Chief Justice Conner explicitly advocated an expansion of common law doctrine:

The courts will poorly perform their functions if they deny a patient hearing and a fearless determination of any demand for relief on the ground that the demand is out of the ordinary, and that no court before has entertained a like plea. To deny relief on such grounds is to deny all change or progress in our laws. ${ }^{149}$

Chief Justice Conner's reasoning was simple. To him, there was no logical reason to see marriage as anything other than a contractual relationship, albeit one creating a status and subject to the control of the state. ${ }^{150}$ While the common law might not recognize an action for breach of contract between

143. Id. at 212.

144. The courts drew support from a then-recent Texas Supreme Court decision, Grigsby v. Reib, 153 S.W. 1124 (Tex. 1913), dealing with the requirements for a valid common law marriage.

145. The leading Texas case at the time, cited by both courts, was Nickerson \& Matson v. Nickerson, 65 Tex. 281 (1886). Nickerson has since been overruled. See Bounds v. Caudle, 560 S.W.2d 925,927 (Tex. 1977); see also Price v. Price, 732 S.W.2d 316 (Tex. 1987).

146. Gowin v. Gowin, 264 S.W. 529, 537 (Tex. Civ. App.-Fort Worth 1924), affd, 292 S.W. 211

(Tex. Comm'n App. 1927, judgm't aff'd).

147. Id. at 538.

148. Id. (Conner, C.J., dissenting).

149. Id.

150. Id. at 540 . 
husband and wife, times were changing. Chief Justice Conner stated that, with the constitutional grant of women's suffrage in $1920^{151}$ and passage of a series of Texas statutes expanding married women's rights, ${ }^{152}$ "[n]o one can doubt that great changes have been made generally in the condition and legal status of woman from that existing in the days of the common law."153 The conclusion of his dissent is an eloquent summary of the philosophical disagreement between the factions of the court:

I am not unmindful of the force of the contrary views of the majority ... ; nevertheless, with the vision in mind of the wives and mothers of men as I know them, I have resolved in their favor whatever of doubt [sic] there may be, and will conclude by saying that, aside from a deep-seated conservatism and very natural tendency of the American bred lawyer to adhere to old standards, I have been unable to find any logical reason for the conclusion that appellee's case is not within the broad general terms of our constitutional guaranties, or that, in such cases, relief, in this day of enlarged recognition of woman's marital rights, should be denied by mere inferences or the pronouncements of law-writers of a different age founded on dissimilar circumstances and different laws. ${ }^{154}$

One should keep in mind that this disagreement between Chief Justice Conner and the rest of the Fort Worth court was an intramural squabble among judicial liberals. This was, after all, the same court that would soon break with precedent in Cunningham, permitting periodic child support payments despite contrary holdings in other appeals courts.

The Texas Commission of Appeals' treatment of Gowin manifests a much more conservative outlook. The first sentence of the opinion sets the tone: "This record exhibits an inexpressibly sordid view of the marital relation, and thus gives emphasis to the importance of the principle involved."155 To the commission, Mrs. Gowin was nothing more than a golddigger. ${ }^{156}$ The court concluded that Ocie Speer's breach of contract theory was contrary to Texas law

151. U.S. CONST. amend. XIX.

152. This legislation is summarized in McKnight, supra note 118, at 118, 124-26. Briefly, a 1911 statute allowed married women to engage in some businesses without the disabilities of coverture. This was followed in 1913 with legislation granting married women some control over community property, in 1915 with a statute setting aside personal injury recoveries as married women's separate property, and in 1917 with legislation making income from separate property also separate property. Id. at 124-25. Much of this legislation was declared unconstitutional by the Texas Supreme Court in 1925, one year after the Gowin dissent. Id. at 125; Cauble v. Beaver-Electra Refining Co, 274 S.W. 120 (Tex. 1925); Gohlman, Lester \& Co v. Whittle, 273 S.W. 808 (Tex. 1925); Arnold v. Leonard, 273 S.W. 799 (Tex. 1925). The statute setting aside personal injury recoveries as separate property was declared unconstitutional in 1927 by Northern Texas Traction Co v. Hill, 297 S.W. 778, 779-80 (Tex. Civ. App.-El Paso 1927, writ ref'd), a decision that was overruled in a different statutory context in 1972. Graham v. Franco, 488 S.W.2d 390, 396 (Tex. 1972).

153. Gowin, 264 S.W. at 542 (Conner, C.J., dissenting).

154. Id. at 545 .

155. Gowin, 292 S.W. at 211.

156. The court, for example, provided a detailed list of presents she received during the courtship: "a string of $\$ 1.25$ white beads, some cut flowers and a box of face powder and a magazine." Id. at 212 . The Commission noted that "[ $t]$ here is in the petition no claim that love . . had anything to do with [the wife's] acceptance of [the husband's marriage] proposal," and viewed her complaint as being that the husband "had offered some of the purchase price alleged and had not paid . . . " Id. 
and could lead to "sexual indulgences flatulently euphemized by such designations as 'free love' and 'trial marriages."'157 The commission further reasoned that some marriage vows are not amenable to contractual remedies. ${ }^{158}$ Also, the commission specifically rejected Chief Justice Conner's concern for fairness to women as an "ad hominem postulate"159 and "nonsequential,"160 because the principle that one spouse could not sue the other for support was facially gender-neutral. Thus, "there is no shadow of discrimination against the woman ...."161

3. The Temper of the Times. What should one make of Cunningham, Gowin, and the other cases foreclosing the possibility of alimony? To be sure, there is more than a trace of a judicial backlash against the women's rights movement. The statement of the Texas Commission of Appeals in Gowin that its ruling contained "no shadow of discrimination against the woman"162 is disingenuous at best. In a legal and social regime that enforced the economic dependence of women on men, this sort of theoretical equality becomes practical discrimination, bringing to mind Anatole France's observation that "[t]he law, in its majestic equality, forbids the rich as well as the poor to sleep under bridges, to beg in the streets, and to steal bread." 163

The opinions, however, also show a more generalized concern with preserving the institution of "traditional" marriage, undoubtedly reflecting a deep concern of the times. ${ }^{164}$ In 1889 , the federal government published the first reliable U.S. divorce statistics, sparking a national debate over a "divorce crisis."165 Subsequent reports fueled the flames. In Texas, for example, figures showed that

157. Id. at 213. Since the case took four years to decide, and since Ocie Speer left practice in 1927 to become one of the commissioners, Section A of the Commission of Appeals in Gowin was put in the unusual position of ruling against one of their brethren on Section B in a case in which he had participated as counsel. While it is reasonable to assume that the language of Gowin might be tempered somewhat by deference to a judicial colleague, one shudders to think of what the commission might have said to make the opinion stronger.

158. "For where is the court so wise and potent as to enforce that mutual love, respect, and benevolence which is the basic vow? What external power shall impel specific performance of the obligation to fructify ...."Id. at 214 .

159. Id. at 212 .

160. Id.

161. Id. at 213

162. Id.

163. Compare John Cournos, A Modern Plutarch 27 (1928) (quoting Anatole France), with Mary Joe Frug, A Postmodern Feminist Legal Manifesto (An Unfinished Draft), 105 HARV. L. REV. 1045, 1052 (1992) (explaining that while many anti-prostitution laws are gender neutral, the fact that most sex workers are women means that "even though anti-prostitution rules could, in theory, generate parallel meanings for male and female bodies, in practice they just don't").

164. The majority opinion of the Court of Civil Appeals in Gowin, for example, describes marriage as "the chief support of the social edifice the world over, and without which the structure would fall." 264 S.W. at 537.

165. See generally William L. O'Neill, Divorce IN THE Progressive ERA 34 (1967); see also Samuel W. Dike, Statistics of Marriage and Divorce, 4 POL. SCI. Q. 592, 592 (1889) ("The appearance of this thick volume marks a great stride in the knowledge both of the laws and their operation regarding these most fundamental of social problems."). 
between 1870 and 1900, the divorce rate in Texas increased more than sixfold. ${ }^{166}$ More alarming was the rate at which Texas was climbing the comparative charts. Texas ranked thirty-first in divorce rate among the states in 1870, twentieth in 1880, fourteenth in 1890, and seventh in $1900 .{ }^{167}$ While low compared to today's standards, ${ }^{168}$ the divorce rate figures were perceived as a dramatic increase over historical norms. Many states, including Texas, tightened their divorce statutes, ${ }^{169}$ and Texas courts-such as the Court of Civil Appeals in Gowin-showed some concern for the effect of their decisions on the Texas divorce rate, which at the time of the decision was said to be the highest in the nation. ${ }^{170}$

In practice, of course, the effect of alimony on divorce rates would be problematical. Providing increased access to alimony might encourage some wives to seek divorce, but it would simultaneously discourage restless husbands from placing their pocketbooks at risk. Since two-thirds of divorce suits were brought by women ${ }^{171}$ however, alimony was probably viewed as encouraging divorce. ${ }^{172}$ This was precisely the concern expressed by the Court of Civil Appeals in Gowin when declining to permit suits for marital support. ${ }^{173}$

While a reaction against the women's rights movement and a desire to discourage divorce may help to explain the "no permanent alimony" rule developed by Texas courts, ${ }^{174}$ these attitudes may only be symptomatic of what

166. See Samuel W. Dike, A Summary of the Chief Points of the United States Marriage and Divorce Report of 1909, at 11, SPECIAL IssUes OF THE NATIONAL LEAGUE FOR THE PROTECTION OF THE FAMILY FOR 1909, No. 2 (1909).

167. Id.

168. The rate in 1900 was 131 divorces per 100,000 people. Id.

169. In 1913, for example, Texas divorce statutes were amended to require one year's residence, a minimum delay of thirty days between filing and decree, and a minimum of one year for remarriage after a divorce granted on the ground of cruel treatment. See generally B.F. LOONEY, BIENNIAL REPORT OF ATTORNEY GENERAL, TEXAS, 1912-14, at 894-95 (1915) (expressing the opinion that the legislation was constitutional as long as not applied retroactively).

170. John J. Cox, Note, Permanent Alimony in Texas!, 6 TEX. L. Rev. 344, 351 (1928).

171. O'NeILL, supra note 165 , at $34 \mathrm{n} .163$.

172. For example, Samuel W. Dike, a prominent advocate of tougher divorce laws, stated that "[a] generous alimony and independence are also sometimes preferred by the wife to continuance in married life." SAMUEl W. Dike, IMPORTANT FEATURES OF THE DiVORCE QUESTION FOR PULPIT TREATMENT 9 (Montpelier, Vt., Watchman \& Journal Press 1885) (reprinted from the Oct./Nov. 1885 Homiletic Review). A professional journalist also announced that alimony laws were responsible for two-thirds of all divorces. Anna Steen Richardson, Easy Alimony, MCClure's MAGAzINE, No. 46, at 16-18 (1916). The latter statement has been criticized as "patently false," since 1910 census figures showed that alimony was awarded in only one of every eleven divorces nationwide. O'NEILL, supra note 165 , at 79. 80.

173. The court reasoned that, since "even a suit between two associates in any commercial business almost invariably leads to a dissolution of the business relation," permitting a suit between marital partners for support "would furnish an added incentive to sue for damages in a suit like the present suit, and also to sue for a divorce and recover such damages in that suit and on the same grounds for which a divorce is sought." Gowin, 264 S.W. at 537-38. One could as easily argue, however, that a law requiring spouses to fulfill marital promises would induce more couples to enter the marital relationship.

174. One problem with viewing judicial decisions denying alimony or spousal support as a reaction to the women's rights movement or the growing incidence of divorce is that most of the early Texas cases discussing alimony and spousal support actually concern child support. It would indeed be a perverse view of public policy to interpret decisions depriving children of food and clothing as somehow 
Chief Justice Conner described in his Gowin dissent as "a deep-seated conservatism."175 Texas judges seem to have been less reform-minded than many other turn-of-the-century Texans. ${ }^{176}$ In a 1909 article, for example, Judge Nelson Phillips ${ }^{177}$ bemoaned the tendency of the legislature "to enlarge the statute book, to extend the scope of legislative control, and to visit regulatory process upon the mass of subjects that lie peculiarly within the pale of private concern." ${ }^{178}$ Examples of this general resistance to change are not hard to find. In addition to undoing marital property reforms in $1925,{ }^{179}$ the Texas Supreme Court in 1923 had declared legislation imposing additional administrative duties on the supreme court unconstitutional, ${ }^{180}$ and in 1934 invalidated eight pieces of debt relief legislation in a single day. ${ }^{181}$ Liberal divorce legislation was identified with "reform" movements. ${ }^{182}$ This fact alone may have aroused the suspicions of normally conservative courts, tipping the scales in favor of a restrictive approach to this difficult social issue.

The most striking aspect of modern Texas alimony doctrine is that it developed without a single reference to the contrary Wiley decision. ${ }^{183}$ Because of the central role played by Ocie Speer in the development of Texas family law during the early years of the twentieth century-as advocate, scholar, judge, commissioner, and legislative draftsman - it is not beyond the realm of possibility that the failure of any Texas court to cite Wiley, or to recognize the theoretical possibility of permanent alimony under Texas law, can be traced simply to Speer's mistaken characterization of the case in his 1901 treatise. Whatever the reason, the only mention of the Wiley decision by any court, in any jurisdiction,

protecting the noble institution of marriage or making a statement regarding the theoretical equality of men and women.

175. Id. at 545 (Conner, C.J., dissenting).

176. One historian has noted that "a chief characteristic of Texas at the turn of the century was the remarkable ease with which citizens addressed themselves to the necessity of reform," setting out a number of particular examples. BILly M. JONES, THE SEARCh FOR MATURITY: THE SAGa Of TEXAS, $1875-1900$, at 179 (1965).

177. Phillips served as an associate justice of the Texas Supreme Court from 1912-15 and as chief justice from 1915 through 1921. 2 HANDBOOK OF TEXAS, supra note 15, at 373.

178. Judge Nelson Phillips, Some Leading Features of the Texas Legal System, 1 TEX. MAG. 13, 15 (1909).

179. See supra note 152. The Texas Supreme Court's decision in Arnold v. Leonard, 273 S.W. 799 (Tex. 1925) is directly contrary to a much earlier California Supreme Court decision construing a provision of that state's constitution copied word-for-word from that of Texas. George v. Ransom, 15 Cal. 322 (1860); see also Michael Diehl, Note, The Trust in Marital Law: Divisibility of a Beneficiary Spouse's Interests on Divorce, 64 TEX. L. REV. 1301, 1311 n.34 (1986). In some respects, Arnold may have been a more favorable decision for women than was George. The Arnold decision, however, evidences a restrictive reading of the Constitution and of the limits of legislative power that worked against the interests of women in other contexts. See, e.g., supra note 152.

180. In re House Bill No. 537 of the Thirty-Eighth Legislature, 256 S.W. 573 (Tex. 1923). Earlier legislation designed to lighten the court's workload passed constitutional muster, but not without a spirited dissent. In re Subdivision Six of Supreme Court Jurisdiction Act of 1917, 201 S.W. 390 (Tex. 1918) (Hawkins, J., dissenting).

181. See, e.g., Travelers' Ins. Co. v. Marshall, 76 S.W.2d 1007 (Tex. 1934); Langever v. Miller, 76 S.W.2d 1025 (Tex. 1934).

182. O'NEILL, supra note 165, at 259.

183. 33 Tex. 358 (1870). See discussion supra part II.C. 
occurred far too late to have any real influence on the development of Texas law. In 1942, in Pearce v. Commissioner of Internal Revenue, ${ }^{184}$ the United States Supreme Court was called upon to decide a tax case involving a Texas alimony trust. While reciting the general Texas rule that "'[p]ermanent alimony is not provided for by ... statute," "185 Justice Douglas also mentioned Wiley, noting that "[a]t times the divorce court has made such a division of the estate as apparently to impose on the husband a personal obligation to make stated payments to his wife." 186 One is left with the clear impression that neither the United States Supreme Court nor the litigants quite knew how to square Wiley with the then clearly established Texas "no permanent alimony" rule. ${ }^{187}$

\section{B. Imaginative Property Division}

While decisions such as Pape and Cunningham may have foreclosed the possibility of alimony in Texas, there was not any widespread agitation for legislative reform, such as occurred with child support. This may be due to the fact that Texas' trial and intermediate appellate courts, left in large part to their own devices by the Texas Supreme Court's limited jurisdiction, used their equitable powers ${ }^{188}$ and statutory authority to devise "property division" techniques often indistinguishable from alimony. Moreover, since custody was usually awarded to the mother, child support payments might well have contained an element of concealed alimony. ${ }^{189}$

184. 315 U.S. 543 (1942).

185. Id. at 548 (quoting Phillips v. Phillips, 203 S.W. 77, 79 (Tex. Civ. App.-Fort Worth 1918, no writ).

186. Id.

187. The opinion mentions Wiley twice, both times using the qualifier "apparently." Id. at 548, 549. Petitioner's brief described Wiley as awarding "the equivalent of alimony," without further explanation. Petitioner's Brief at 12, Pearce v. Commissioner of Internal Revenue, 315 U.S. 543 (1942) (No. 306 ). The government conceded that Wiley "seems to conflict with the rule stated in the later cases, although possibly the alimony there granted was actually a charge only against the husband's property, and not a debt." Brief for the Respondent at $19 \mathrm{n.5}$, id.

188. See, e.g., Harrington v. Harrington, 451 S.W.2d 797 (Tex. Civ. App.-Houston [1st Dist.] 1970, no writ) (holding that court has discretion in property division to take into account disparaties in wealth, earning power, business opportunities, and financial background). This view was not new, however. In Fitts, the Texas Supreme Court cited with approval an Alabama decision, construing legislation substantially identical to the Texas statute, to the effect that

no construction can be put upon the statute that would authorize the Court, in any case to do less than provide a maintenance for the wife, if the estate of the husband be sufficient for that purpose. She should be enabled, if her husband's estate were such as to justify it, to live in such a manner as that, if possible, she may regain her lost standing in society.

14 Tex. 443, 451 (1855) (summarizing Lovett v. Lovett, 11 Ala. 763 (1847)).

189. There is some anecdotal evidence to support this hypothesis. Men's advocacy groups claim that in states that have restricted alimony, judges compensate by inflating child support awards. See, e.g., "Men's Lib" Movement Trains Its Guns on Divorce Courts, U.S. NEWS \& WORLD REP., Sept. 12, 1977, at 42. In Texas legislative hearings on spousal support, Professor John J. Sampson expressed a similar opinion. When asked, "Don't you think that exactly what we're doing now is shutting our eyes and calling [alimony] child support?," he replied, "It has happened historically a lot, I'm sure." Hearings on Tex. H.B. 697 Before the House Jud. Affairs Comm., 71st Leg (Mar. 29, 1989) (tape on file with the author). At least one witness testified in favor of the spousal support bill "to get this hidden alimony out of child support and make it a little legitimate." Testimony of Mr. Bert Pence, id. The spousal support bill's author, Rep. Nicholas Perez, also expressed the opinion that Texas courts formerly had the 
During this middle period, Texas appellate courts sometimes approved the award of one spouse's separate personal property to the other, "limited only by the dictates of reason." 190 Courts also invaded separate real property, building on the 1855 Fitts holding that separate real estate of one spouse could be put in trust for the benefit of the other. ${ }^{191}$ This holding was reiterated in a 1923 Texas Supreme Court decision approving an award to the wife of a life estate in the husband's separately owned homestead. ${ }^{192}$ Depending on the circumstances, the husband, wife, or third persons might be designated to manage separate "trust" property. 193

Property division sometimes even took the form of continuing monthly payments from one spouse to another, provided that the payments were somehow "referable to" property in existence at the time of the divorce. Thus, in McBean v. McBean, ${ }^{194}$ payments of one hundred dollars a month until death or remarriage were permitted because the husband was awarded substantially all the community property, including sixty-five acres of land. The payments were allowed despite the husband's claim that "there was more owed on the property than it was worth; and that such property never appreciated in value; and that he sold it at a loss." ${ }^{195}$ Likewise, in Clark $v$. Clark, ${ }^{196}$ the wife was awarded twenty-five dollars a month, money tied to expected revenues from the husband's separate real estate. ${ }^{197}$ When the husband died, his executor argued that the judgment was void because it was "in legal effect merely an award of permanent alimony."198 As an alternative position, the executor pointed out that, because of the depressed economy (the divorce was granted one month after the stock market crash of 1929), ${ }^{199}$ the property did not generate twenty-five dollars a

ability "in the child support area, to try to come up with a fair result." Testimony of Rep. Nicholas Perez, id. Rep. Perez added, however, that mandatory child support guidelines have now removed that discretion. Id.

Of course, child support can serve as a partial substitute for alimony only if that support is actually paid. Historically, Texas has not permitted the garnishment of current wages for child support. In consequence, in 1983, Texas ranked dead last in a national survey regarding effectiveness in the collection of child support, Texas News Briefs, UPI, July 22, 1983, with $70 \%$ of all parents not making court-ordered payments. Tim Sheehy, Texans to Decide Garnishment of Wages for Child Support, UPI, Nov. 11, 1983. Since the passage of a constitutional amendment authorizing the garnishment of wages for child support, Texas has improved to 19th place. Feds Say Texas Has Improved Child Support Collection Efforts, UPI, Jan. 11, 1991.

190. Morris Atlas, Comment, Settlement of Marital Property Rights Upon Divorce, 29 TEX. L. REV. 355,365 (1951).

191. See discussion supra part II.B.

192. Hedtke v. Hedtke, 248 S.W. 21 (Tex. 1923). The Hedtke result has been characterized by one recent commentator as "quasi-alimony." Diehl, supra note 179 , at $1314 \mathrm{n} .47$.

193. See, e.g., Jones v. Jones, 211 S.W.2d 269 (Tex. Civ. App.-El Paso 1944, no writ) (wife put in charge of husband's property); Clark v. Clark, 35 S.W.2d 189 (Tex. Civ. App.-Waco 1930, writ dism'd) (husband left in charge of his own property, with the obligation to make monthly payments to the wife).

194. 371 S.W.2d 930 (Tex. Civ. App.-Waco 1963, writ refd).

195. Id. at 931 .

196. 35 S.W.2d 189.

197. Id. at 190.

198. Keton v. Clark, 67 S.W.2d 437, 438 (Tex. Civ. App.-Waco 1930, no writ).

199. Clark, 35 S.W.2d at 190. 
month in revenue. ${ }^{200}$ Finally, the executor argued that, like alimony payments in general, the obligation terminated at the husband's death. ${ }^{201}$ The executor lost on all counts. The court decided the claim was a property award, not alimony, and thus survived the husband's death. ${ }^{202}$ The court insisted that continuing monthly payments be made from whatever cash the husband had on hand at the time of his death, whether the property was producing revenues or not, in effect giving the ex-wife the best possible result. ${ }^{203}$

Often, a combination of property division techniques would be used to achieve a desired result. In Berg $v$. Berg, ${ }^{204}$ the court approved an award of a life estate in the community home and seventeen dollars and fifty cents a month for living expenses, paid out of the husband's railroad retirement pension, in part because the ex-wife "is unable to make a living for herself; . . . she has nowhere to go." 205 While some part of the pension was earned during marriage, the court made it quite clear that it would have approved the judgment even if the pension had been earned entirely before marriage. ${ }^{206}$ Referring to Berg, a Texas attorney commented in 1940 that "[i]t is only a short step to an award out of personal earnings and full fledged permanent alimony."207

A similar result was reached by a Dallas appellate court in Helm v. Helm, ${ }^{208}$ a decision issued the same year its neighboring court in Fort Worth was wrestling with Cunningham. In Helm, the couple had no children and little community property. The trial court enjoined the husband from disposing of the couple's home and $\$ 25,000$ in bonds, both his separate property, pending the divorce. ${ }^{209}$ The Dallas court approved the injunction, implying that a decision to give the wife a life interest in the home and $\$ 25,000$ in bonds would not be objectionable. ${ }^{210}$ This decision prompted a highly critical student note in the Texas Law Review. ${ }^{211}$ The author pointed out that the principal distinction between the "property division" in Helm and true alimony was that Mr. Helm could not escape his "property division" obligation by going to jail or fleeing the jurisdiction. ${ }^{212}$ A more sympathetic student writer of the early 1950s, now one of Texas' most prominent lawyers, observed that, under the guise of the property division statute,

200. Keton, 67 S.W.2d at 440 .

201. Id.

202. Id.

203. Id.

204. 115 S.W.2d 1171 (Tex. Civ. App.-Fort Worth 1938, writ dism'd w.o.j.).

205. Id. at 1172 .

206. Id.

207. George M. Feild, a Treatise on the Law Relating to Dissolution of the Marital RELATION $\& 56$, at 41 (1940).

208. 291 S.W. 648 (Tex. Civ. App.-Dallas 1927, no writ).

209. Id. at 649 .

210. Id. at 650 .

211. Cox, supra note 170 , at 351 .

212. Id. at 344. 
the courts manage to reach just results is [sic] most cases by considering the positions of the parties and their needs. From the standpoint of prediction, this is the important fact. Since the only limitation applies to real estate, and since the decisions have at least partially "cured" this inhibition, the courts are at liberty to deal out justice between the parties and their children. ${ }^{213}$

This is how matters stood until the 1970s.

\section{Alimony by Contract}

No attempt to describe the broad contours of Texas alimony law would be complete without some discussion of the dispute over enforcement of contractual alimony agreements. Beginning no later than the 1940s, contractual alimony provisions became popular in Texas divorce settlements. ${ }^{214}$ While it may seem odd that many Texas spouses would do by agreement what they could not be required to do by law, at least three possible motives could lead to a contract for alimony. First, contractual alimony could be the quid pro quo for a spouse's consent to divorce. In a fault-based divorce system, the innocent spouse had some bargaining power. ${ }^{215}$ If the spouse with the greater earning power-usually the husband-wanted a divorce, but had no fault-based ground, contractual alimony might secure the wife's agreement not to contest the suit. Second, tax considerations sometimes made contractual alimony payments a financially attractive alternative to property division. ${ }^{216}$ Finally, some husbands may have felt morally obligated to provide support, though the case law reveals that they occasionally changed their minds once the divorce became final.

In 1953, Colonel McBride changed his mind. He had agreed to pay his exwife one-third of his monthly income, not to exceed $\$ 200$ a month, until she remarried or their son reached twenty-one years of age. ${ }^{217}$ The colonel remarried. When he and his new wife were expecting their second child, he sued to modify the contractual alimony payments because of changed circumstances, or, in the alternative, to avoid the judgment because contractual alimony was against Texas public policy. ${ }^{218}$ The Austin Court of Civil Appeals decided that

213. Atlas, supra note 190 , at 366 .

214. See, e.g., Beam v. Southwestern Bell Tel. Co., 164 S.W.2d 412 (Tex. Civ. App.-Waco 1942, writ ref'd w.o.m.).

215. Recent research, however, suggests that this bargaining power may not have been as great, or that the effect of no-fault divorce may not have been as large as many had previously thought. See, e.g., Stephen D. Sugerman, Dividing Financial Interests on Divorce, in DIVORCE REFORM AT THE Crossroads 133 (Stephen D. Sugerman \& Herma Hill Kay eds., 1991) (reporting from his analysis of California data that "between 94 and 98 percent of women were treated the same under both systems in terms of whether they were awarded spousal support. Put the other way, between two and six women in a hundred do not get alimony who previously did. I do not deny that this is a change, but it hardly seems an important change.").

216. See generally Edward W. Turley, Jr, Divorce and Taxes-Texas Style, 48 TEX. L. REv. 721 (1970). This was more true when the range of federal marginal tax rates was greater than today. If the ex-husband, deducting alimony, was in the $50 \%$ bracket and the ex-wife, who took the payments into income, was in the $15 \%$ bracket, the federal government substantially subsidized the arrangement.

217. McBride v. McBride, 256 S.W.2d 250, 251 (Tex. Civ. App.-Austin 1953, no writ).

218. Id. at 251-52. 
the payments could not be viewed as a form of property division because the decree was not "referable to" any property. ${ }^{219}$ Nor could the payments have been intended as child support, since that was provided for separately in the divorce decree. ${ }^{20}$ Concluding that the contract payments were alimony, the Austin court decided that the agreement could not be enforced by court order. "First and foremost," the court declared, "the Court has no jurisdiction and is without authority to grant permanent alimony."221 Second, citing Cunningham, the court observed that "the award of permanent alimony is against the public policy of this State."222 Because a contract against public policy is void, McBride's agreement could not be enforced as a contract. ${ }^{223}$

As already noted, the Austin court in $M c B$ ride can claim the dubious distinction of being the first to declare that permanent alimony is contrary to Texas public policy. ${ }^{224}$ Fourteen years later, McBride was disapproved by the Texas Supreme Court in another military divorce case, Francis v. Francis. ${ }^{225}$ Colonel Francis sued for declaratory judgment claiming that a purported "property division" agreement obligating him to make monthly payments over a period of years was nothing more than void contractual alimony. The El Paso Court of Civil Appeals followed $\mathrm{McB}$ ride in concluding that this portion of the decree was indeed void. ${ }^{226}$ The Texas Supreme Court reversed.

The Texas Supreme Court's reasoning was simple, even superficial. "Alimony," reasoned the court, citing a number of decisions from other jurisdictions, is defined as payments made for spousal support "pursuant to an order or decree by the court." 227 Thus, the only alimony that "contravenes the public policy of the state" is that alimony that is "imposed by a court order."228 In consequence, a contractual alimony agreement cannot be enforced by the court, but " $[t]$ he agreement will ... have whatever legal force the law of contracts will give to it."229 Any doubt that McBride's "void contract" analysis

219. Colonel McBride owned very little at the time of the divorce, and his wife received most of what he did have. Id. at 252-53.

220. Id. at 253.

221. Id. (emphasis in original).

222. Id. at 254.

223. A student note on $M c B$ ride criticized the court's contract analysis as dicta and suggested that "a property settlement providing for monthly payments to the wife serves a real need." Joel $H$. Pullen, Note, Divorce-Permanent Alimony-Ability of Husband to Contract With Wife for Her Support After Divorce-McBride v. McBride, 256 S.W.2d 250 (Tex. Civ. App.-Austin 1953), 32 TEX. L. REV. 343, 344 (1954). The Texas Supreme Court has also characterized this aspect of McBride as resting on dicta. See Francis v. Francis, 412 S.W.2d 29, 33 (Tex. 1967).

224. See supra discussion in text accompanying notes $129-34$

225. 412 S.W.2d 29.

226. Francis v. Francis, 407 S.W.2d 295 (Tex. Civ. App.-El Paso 1966), rev'd, 412 S.W.2d 29 (Tex.

1967).

227. 412 S.W.2d at 32 (emphasis in original).

228. Id. at 33 .

229. Id. 
had been overruled was removed by the court's conclusion that $M c B$ ride was "disapproved" on that score. ${ }^{230}$

The court's reasoning in Francis leaves much to be desired. If alimony were really against public policy, the rule of $M c B r i d e$ should have stood: A contract against public policy should not be enforced. ${ }^{231}$ If, on the other hand, the "public policy" against alimony mentioned by the court in Francis is not strong enough to supersede private contract rights, it does not have legal significance. The court's conclusion that alimony is "defined" as court-ordered payments likewise does not bear close analysis. While alimony once was awarded by legislatures, not civil courts, ${ }^{232}$ that power now typically is delegated exclusively to the courts. ${ }^{233}$ In Francis, therefore, the court's discussion of the "definition" of alimony is only a convoluted way of saying that, in modern times, courts-not legislatures-usually grant divorces and award alimony. ${ }^{234}$ In McBride, rather than "defining" alimony as court-ordered payments, the court avoided these definitional gymnastics by stating that Texas courts have no statutory authority to award alimony. Nonetheless, the confused language of Francis is now cited by Texas courts as proof of some nebulous "public policy" against court-ordered postdivorce payments. ${ }^{235}$

\section{IV}

\section{Neither Alimony Nor Equity (1969 to THE Present)}

In 1969, the Texas Legislature ushered in a new era of family law, under the guise of the Texas Family Code. While the politics of the situation are fascinating in their own right, ${ }^{236}$ two changes are of particular interest to the law of spousal support in Texas. First, Texas adopted a scheme of "no-fault" divorce. ${ }^{237}$ Second, possibly by accident, the Texas Legislature deleted the

230. Id. In McBride, the Texas Supreme Court explained that the real problem was that the trial court ordered Colonel McBride to make the payments. Id.

231. See, e.g., Woolsey v. Panhandle Refining Co., 116 S.W.2d 675 (Tex. 1938) (refusing to enforce a contract circumventing state workers compensation law).

232. Clark, supra note $18, \S 16.1$, at 620 .

233. See supra discussion in text accompanying notes 18-21.

234. Moreover, it is not difficult to find definitions of alimony that do not contain the phrase "courtordered." In Black's Law Dictionary, for example, permanent alimony is defined as a "provision for the support and maintenance of a wife during her lifetime." BLACK'S LAW DICTIONARY 67 (5th ed. 1979). Likewise, under the Internal Revenue Code, the alimony deduction is given for contractual as well as court-ordered alimony. I.R.C. \& 71(b)(2)(B) (West 1988). As one court put it, "[t] he word [alimony] has several recognized meanings which vary greatly according to the subject-matter and language used in connection with it." Electric Reduction Co. v. Lewellyn, 11 F.2d 493, 494 (3d Cir. 1926).

235. See, e.g., Stubbe v. Stubbe, 733 S.W.2d 132, 133 (Tex. 1987); Mackey v. Mackey, 721 S.W.2d 575, 578 (Tex. App-Corpus Christi 1986, no writ); Klise v. Klise, 678 S.W.2d 545, 548 (Tex. App.-Houston [14th Dist.] 1984, no writ).

236. The subject is treated in some detail elsewhere in this issue. See McKnight, supra note 44, at 87 (describing the Texas Family Code as originating in a desire by the State Bar of Texas to blunt the women's rights movement, transformed by academicians into something approaching fairness).

237. The Family Code added the new ground of "insupportability," defined as "discord or conflict of personalities that destroys the legitimate ends of the marriage relationship and prevents any reasonable expectation of reconciliation." TEX. FAM. CODE ANN. \$ 3.01 (West 1975). Divorce on this 
statutory language prohibiting divestiture of separate real estate upon divorce. $^{238}$ Each of these changes had a major, and unanticipated, negative impact on the ability of Texas courts to achieve equitable results in divorces.

\section{A. "No Fault" Divorce}

No sooner had the Texas Supreme Court approved contractual alimony agreements in Francis than the Texas Legislature removed the primary incentive to enter into such agreements by adding "insupportability" as a no-fault statutory ground for divorce. As Professor McKnight has observed, "It is one of the great ironies of that reform [no-fault divorce] that the bargaining power of the innocent spouse was thereby swept away."239 While there is no evidence that the legislature intended any such result, and recent studies question the extent to which such consequences actually occurred, ${ }^{240}$ the advent of no-fault divorce brought the problems of propertyless marriages into high relief. State senator Santiesteban, an attorney and co-sponsor of the no-fault divorce bill, reported that in his family law practice, he began to see two or three clients a week who needed, but were unable to get, some form of postdivorce support. "Before the no-fault bill, they would have got those [commitments] with negotiating."241 Enactment of the no-fault legislation "in essence . . . took away the negotiation from the other party." ${ }^{242}$ In reaction to the unintended bad effects of no-fault divorce in Texas, Senator Santiesteban repeatedly sponsored spousal support legislation. ${ }^{243}$

No-fault divorce also seems to have a psychological effect on alimony awards. Since alimony has traditionally been fault-based, a decision to award alimony after a no-fault divorce may seem anomalous. Perhaps as a consequence of this anomaly, the advent of no-fault divorce in states other than Texas began a shift toward short-term, "rehabilitative" alimony awards. ${ }^{244}$ Another national trend, the adoption by common law states of "equitable distribution" schemes for

ground became "a simple and perfunctory procedure." Edward W. Turley, Jr., A Wife's Right to Support Payments in Texas, 16 S. TEX. L.J. 1, 53 (1974).

238. TEX. FAM. Code ANN. \& 3.63 (West Supp. 1992).

239. Joseph W. McKnight, Family Law, Southern Methodist University School of Law Symposium,

Texas Law: Its Development and Reform From 1836 to 1936, at 18 (Oct. 17, 1986).

240. See supra note 215.

241. Sen. H. Tati Santiesteban, quoted in Marilyn Kay Kuehler, The Big Shoot-Out Over Alimony, FAM. WKLY., Jan. 29, 1984, at 21.

242. Hearings on Tex. S.B. 452 Before the Subcomm. on Civil Matters of the Sen. Jur. Comm., 65th Leg. (March 8, 1977) (statement of Senator H. Tati Santiesteban) (tape on file with the author) [hereinafter Hearings on S.B. 452].

243. See, e.g., Tex. S.B. 452, 65th Leg. (1977); Tex. S.B. 711, 66th Leg (1979); Tex. S.B. 632, 68th Leg. (1983); see also Kuehler, supra note 241, at 21.

244. See Sally F. Goldfarb, Marital Partnership and the Case for Permanent Alimony, 27 J. FAM. L. 351, 352-53 (1988-89); Lenore Weitzman \& Ruth Dixon, The Alimony Myth: Does No-Fault Divorce Make a Difference?, 14 FAM. L. Q. 141, 161-62 (1980); REPORT ON THE NECESSITY AND DESIRABILITY OF Allowing Court ORdered Spousal MainTENANCE in TeXas 59-60 (Nov. 1986) (Texas House of Rep., Comm. on the Jud.) [hereinafter TEXAS HOUSE JUdICIARY REPORT]. 
property division at divorce, ${ }^{245}$ also may have contributed to this decreasing reliance on alimony. ${ }^{246}$

The difficulty in squaring no-fault divorce and equitable division of property with traditional justifications for alimony is perhaps best illustrated by a 1976 Idaho decision, Olsen v. Olsen ${ }^{247}$ Although the case dealt with the relatively mundane question of the factors justifying modification of an alimony order, the decision triggered a lengthy dissenting opinion. Justice Shepard questioned whether modern society has any continuing need for alimony, stating that "[s]omehow the legitimate interest of society in preventing destitute divorcees ... from being cast upon the relief rolls has been perverted into an instrument to level economic disparities, both real and imagined, between two people in which there exists no legal relationship."248 Justice Shepard rejected the rationale of fault or punishment as the basis for an alimony award as "nothing short of ludicrous"249 in an era of no-fault divorce. He likewise rejected the idea of alimony as "just compensation for [the wife's] faithful contribution to the marriage," reasoning that "[i]f compensation there need be, community property laws adequately and fairly fulfill this function ...."250

Having disposed of all traditional reasons for alimony, Justice Shepard concluded that alimony may be an idea "whose time has past [sic]." $251 \mathrm{He}$ suggested that the Idaho Supreme Court should declare the state's alimony statute void, thus joining the other states that prohibited permanent alimony at the time. He stated that "[i]n each of th[e]se states alternative provisions have been made to insure a fair ... accounting upon divorce and to protect the interests of society in preventing the creation of charity cases."252 To Justice Shepard, Texas was the lone star pointing the way to this brave new alimony-less world:

Texas is perhaps the most interesting example since it has never recognized permanent alimony and yet has somehow been able to avoid having a disproportionate number of charity dependent divorcees on its welfare rolls and because Texas, like Idaho, is a community property jurisdiction. Historically, from earliest times alimony has been denied in Texas and it is now regarded as void against public policy. ... Property division is recognized as the substitute for alimony .... and the Texas courts are vested with wide discretionary power to divide property in such way as will seem "right, just and proper." 253

245. Every state now provides to some extent for the division of property at divorce. Mary Jane Connell, Note, Property Division and Alimony Awards: A Survey of Statutory Limitations on Judicial Discretion, 50 FORDHAM L. REV. 415, 415 (1981).

246. See, e.g., id.

247. 557 P.2d 604 (Idaho 1976).

248. Id. at 612 (Shepard, J., dissenting).

249. Id.

250. Id. at 613,614 .

251. Id. at 615 .

252. Id.

253. Id. (citations omitted). 
Leaving questionable assumptions about Texas history and welfare statistics to one side, Justice Shepard's dissenting opinion was a somewhat reasonable view of the merits of the Texas system, provided that community property laws were liberally and imaginatively applied, and some property was available for division. Ironically, the Olsen opinion issued only six months before the elaborate Texas property division scheme, which had developed over more than a century, began to collapse, through a remarkable series of court decisions.

\section{B. Revisionist Community Property Doctrine}

An outside observer in the early 1970 s might reasonably have concluded that the Texas Legislature unwittingly struck an equitable balance in the Family Code: While no-fault divorce inadvertently decreased an innocent spouse's bargaining power, the Texas Family Code's equally unintentional deletion of the prohibition against divestiture of separately owned real estate simultaneously enhanced the divorce court's equitable powers. ${ }^{254}$ Unfortunately, in a surprising trio of opinions, a bare majority of the Texas Supreme Court ignored the latter change and, worse, reversed more than a century of precedent by ruling that all separate property, not just real estate, was constitutionally exempt from division. 255

It is probably not possible to determine with any certainty precisely why the Texas Legislature omitted the historic language from section 3.63 of the Family Code that prohibited a divorce court from divesting title to separate realty. Because the legislature's current practice of recording debates and committee meetings had not begun at the time of the Family Code's passage, direct evidence of intent is difficult to find. The Code was drafted by academicians and practitioners, and was adopted largely as written. However, even the opinions of the drafters vary on this point: In the drafters' commentary prepared under the supervision of Professor Joseph McKnight, the text of section 3.63 was labeled a codification of prior law; ${ }^{256}$ Professor Eugene Smith, who also participated in drafting the Code, believed that the deletion was meant to change prior law. ${ }^{257}$

In any event, Texas law on the subject of statutory construction is, or should have been, relatively clear: Omission of language from a statute indicates an intent to make a change. ${ }^{258}$ Moreover, since the language of the statute is the clearest evidence of intent, legislative history is not relevant unless the statute itself is ambiguous. ${ }^{259}$ Unsuccessful attempts in subsequent legislative sessions

254. TEX. Fam. Code ANN. $\$ 3.63$ (West Supp. 1992).

255. These decisions, in order of issuance, are Eggemeyer v. Eggemeyer, 554 S.W.2d 137 (Tex. 1977); Campbell v. Campbell, 23 Tex. Sup. Ct. J. 391 (June 4, 1980), withdrawn, 613 S.W.2d 236 (Tex. 1980); Cameron v. Cameron, 641 S.W.2d 210 (Tex. 1982).

256. See Joseph W. McKnight, Commentary on Section 3.63, 5 TEX. TECH L. REV. 337, $337-38$ (1974).

257. Eugene L. Smith, Family Law, 26 Sw. L.J. 51, 55 n.30 (1972).

258. See, e.g., Gateley v. Humphrey, 254 S.W.2d 98, 100 (Tex. 1952).

259. See, e.g., Railroad Comm'n of Texas v. Miller, 434 S.W.2d 670, 672 (Tex. 1968). 
to re-insert the repealed language ${ }^{260}$ suggested that some legislators also perceived a change. Most Texas appeals courts concluded that a substantive change in the law had occurred and began to approve the divestiture of separate real property in divorces. ${ }^{261}$ A couple of others, apparently believing that the omission was unintentional, continued to prohibit divestiture. ${ }^{262}$

In 1977, in Eggemeyer v. Eggemeyer, ${ }^{263}$ the Texas Supreme Court resolved this conflict among the courts by holding that, no matter what the statute may say, the Texas Family Code did not change previous law. To bolster its dubious reading of the statute, ${ }^{264}$ the court dropped a bombshell, reversing at least 120 years of case law by announcing that the Texas Constitution prohibited the divestiture of separate real estate and, by implication, separate personal property. Academic reaction to the decision runs the gamut, from a supporter hailing it as a "welcome breath of fresh air in the musty atmosphere of over 100 years of erroneous decisions of intermediate appellate courts" 265 to an opponent calling it "[p]erhaps the most controversial and potentially disruptive decision in Texas history regarding division of property on divorce." 266 However, all would agree that the decision was, at a minimum, "[s]omewhat startling."267 A brief review of the reasoning is an essential part of the Texas alimony story.

The court's primary conclusion in Eggemeyer, in a section of the opinion remarkably free of analysis, ${ }^{268}$ was that the Texas Legislature changed nothing

260. See Tex. H.B. 102, 63d Leg. C.S. (1973); Tex. H.B. 524, 65th Leg. C.S. (1977).

261. See, e.g., Dietz v. Dietz, 540 S.W.2d 418 (Tex. Civ. App.-El Paso 1976, no writ); Wilkerson v. Wilkerson, 515 S.W.2d 52 (Tex. Civ. App.-Tyler 1974, no writ).

262. See, e.g., Eggemeyer v. Eggemeyer, 535 S.W.2d 425 (Tex. Civ. App.-Austin 1976), affd, 554 S.W.2d 137 (Tex. 1977).

263. 554 S.W.2d 137 (Tex. 1977).

264. Language used in this section of the article occasionally may seem to lack the proper degree of academic objectivity or respect for the judicial function. It is therefore worth noting that the author is well-acquainted with several of the judges involved in the decision, and shares the feelings of respect for them that they enjoy among the bar. Eggemeyer simply seems to generate strong feelings, even in the academic community. See, e.g., William A. RePPY, JR. \& CYNTHIA A. SAMUEL, Community PROPERTY IN THE UNITED STATES 378-79 (2d ed. 1982) (describing Eggemeyer, like its kindred cases, as an "[a]bsurdity."); Sampson, supra note 130, at 1285, 1337 n.176 ("My hostility to the Eggemeyer decision may color my interpretation, but I cannot do better with the court's explanation of this point.").

265. James N. Castleberry, Jr., Constitutional Limitations on the Division of Property Upon Divorce, 10 ST. MARY's L.J. 37, 37 (1978). Dean Castleberry's article, however, also discusses several Texas Supreme Court opinions that are inconsistent with Eggemeyer, making it clear that the Eggemeyer court was doing something more than leading some "intermediate appellate courts" back to the straight and narrow constitutional path. See id. at 39 n.20, 40, 49-50.

266. Sampson, supra note 130 , at 1336.

267. Joseph W. McKnight, Family Law: Husband and Wife, 32 Sw. L.J. 109, 123 (1978); see also Oliver S. Heard, Jr. \& Richard R. Orsinger, Recent Significant Family Law Decisions I-46, in STATE BAR OF TEXAS, MARRIAGE DISSOLUTION (1985) (noting that Eggemeyer "started a fire-storm of controversy among family lawyers and commentators").

268. The court based this conclusion on Professor McKnight's commentary that indicated that no change was intended and on the analysis of language in the Family Code's provision for child support. Eggemeyer, 554 S.W.2d at 139. The opinion offers no theory of statutory construction to justify use of McKnight's commentary. The analysis of the child support provision, while muddled, appears to be that since property can be "administered" for the benefit of children, it can neither be administered nor divested for the benefit of an ex-spouse. Id. The dissenting opinion characterizes the discussion of child support as "irrelevant" and offers convincing arguments to support this conclusion. Id. at 145 (Steakley, 
when it dropped the "no divestiture of separate realty" language from the property division statute. ${ }^{269}$ The court bolstered this holding with three additional arguments, each of which struck directly at the divorce court's equitable power to divide property. First, the court stated that because the statute used the singular "estate of the parties," rather than the plural "estates," only community property could be divested. ${ }^{270}$ The import of this argument was that no separate property - whether personalty or realty-could be divested in a property division. While the Eggemeyer dissenters persuasively criticized the majority's reasoning, ${ }^{271}$ neither opinion adequately considered a venerable decision that had long before covered the same ground, though reaching precisely the opposite conclusion: Chief Justice Hemphill's opinion in Fitts v. Fitts. ${ }^{272}$

In Fitts, as already discussed in some detail, ${ }^{273}$ Chief Justice Hemphill reviewed the legislative background of the original Texas property division statute. Having observed that the "estate of the parties" language was virtually identical to an Alabama statute, ${ }^{274}$ Hemphill, in Rice v. Rice, drew the obvious conclusion: As explained more fully in this later case, the "estate of the parties" language cannot mean "community property" because "[ $t$ ]he provision about the division of the estate of the parties is found in [States] [(for example, Alabama and Kentucky)] where community property is unknown."275

The Eggemeyer court was certainly aware of the Fitts decision. ${ }^{276}$ The court's decision to focus on the precise wording of the 1840 statute, to the exclusion of legislative intent, while simultaneously ignoring the wording of the 1969 codification and exalting legislative intent, adds a layer of irony to the decision.

The Texas Supreme Court's other two arguments in Eggemeyer-both to the effect that the Texas Constitution prohibits the divestiture of separate property-are even more disturbing since, if taken seriously, they would immunize the court's decision from legislative revision. Picking up on the court's anti-women's rights decisions of 1925, the court concluded that the Texas Constitution's

J., dissenting on reh'g).

269. One of many ironies in the decision can be found in the court's citation of the 1931 Cunningham decision as general background. Eggemeyer, $554 \mathrm{~S}$.W.2d at 142 . The court evidently did not notice that, in Cunningham, the Texas Supreme Court employed the reverse of Eggemeyer's statutory analysis, concluding that when language in the 1837 divorce statute was not carried forward in the 1841 enactment, permanent alimony was excluded by implication. See discussion at text accompanying notes 125-26. The only similarity between the two opinions is that the wife lost each time. As the author of Eggemeyer observed, though in a far different context, "[t]here is no greater inequality than the unequal treatment by the same court of things that are equal." Duncan v. Cessna Aircraft Co., 665 S.W.2d 414, 439 (Tex. 1984) (Pope, C.J., dissenting).

270. Eggemeyer, 554 S.W.2d at 139.

271. Id. at 143-44 (Steakley, J., dissenting).

272. 14 Tex. 443 (1855).

273. See discussion supra part II.B.

274. Fitts, 14 Tex. at 450 .

275. Rice v. Rice, 21 Tex. 58,68 (1858).

276. Fitts was cited twice by the court in Eggemeyer. See 554 S.W.2d at 138, 139. The court also quoted from the later Rice opinion, though for a different point. Id. at 141. 
definition of separate property ${ }^{277}$ prohibited legislative initiatives infringing on separate property rights. ${ }^{278}$ The dissenters pointed out that the Texas Constitution grants to the legislature the power to "'more clearly defin[e] the rights"' of spouses. ${ }^{279}$ Again, neither Eggemeyer opinion considered Chief Justice Hemphill's opinion in Fitts, which discussed the constitutional definition of separate property but did not treat it as any sort of limitation on judicial power to award one spouse's property to the other at the time of divorce. ${ }^{280}$

Finally, the court relied on the Texas Constitution's "due course of law" provision, ${ }^{281}$ concluding that Mr. Eggemeyer's substantive due process rights were violated. ${ }^{282}$ Recognizing that a taking must have a "justifying public purpose," 283 the court concluded that "[t]here is no contention that the taking of Homer [Eggemeyer]'s separate property and its transfer to Virginia [Eggemeyer] is justified by any benefit to the public welfare." 284

The court's due process analysis has received particularly strong criticism. ${ }^{285}$ Even Professor McKnight, whose Family Code analysis constitutes the sole "legislative history" supporting the court's conclusion, states that this part of the

\section{The Texas Constitution stated, in part, that}

[a]ll property, both real and personal, of the wife, owned or claimed by her before marriage, and that acquired afterward by gift, devise or descent, shall be the separate property of the wife; and laws shall be passed more clearly defining the rights of the wife, in relation as well to her separate property as that held in common with her husband; ....

TEX. CONST. OF 1876, art. XVI, $\S 15$ (amended 1955). A 1980 amendment has since substituted more gender-neutral language.

278. Eggemeyer, 554 S.W.2d at 140.

279. Id. at 146 (Steakley, J., dissenting) (quoting TEX. CONST. OF 1876, art. XVI, $\S 15$ (amended 1955)). The dissent also catalogued judicially created exceptions to the literal interpretation of the Texas Constitution relied upon by the majority. Professor McKnight later agreed, commenting that Eggemeyer is "out of step with the court's approach when it last examined that provision [Article XVI, $\S 15$ of the Texas Constitution]." McKnight, supra note 41, at 109, 124.

280. Fitts, 14 Tex. at 449-50; see also supra notes 57-60 and accompanying text.

281. "No citizen ... . shall be deprived of life, liberty, property, privileges or immunities, or in any manner disfranchised, except by the due course of the law of the land." TEX. CONST. OF 1876 art. I, \& 19 (amended 1984).

282. Eggemeyer, 554 S.W.2d at 140-41.

283. Id. at 140 (citing Thompson v. Consolidated Gas Util. Corp., 300 U.S. 55, 80 (1937)).

284. Id. at 141. Virginia Eggemeyer's failure to argue any "public benefit" to justify a "taking" is neither surprising nor indicative of any failure on counsel's part. The "due process" argument seems to have been raised sua sponte. Neither party's briefs mentioned substantive due process or, for that matter, the Texas Constitution or the "estate of the parties" argument. Mrs. Eggemeyer argued that the 1969 legislation should be given effect by permitting the divestiture of realty; the closest Mr. Eggemeyer came to a constitutional argument was a statement that a broad reading of the 1969 enactment would be "a direct violation of our strong and established history stemming from civil law, Spanish law, law of the Texas Republic and our State of Texas." Brief of Respondent at 9; see also Brief of Petitioner, Eggemeyer v. Eggemeyer, 554 S.W.2d 137 (Tex. 1977) (No. B-6019). Thus, due process, unconstitutional divestiture and "estate of the parties" all made their debut in the Texas Supreme Court's opinion.

285. In a later case, two prominent Texas family scholars-John J. Sampson of the University of Texas and Eugene L. Smith of the University of Houston-joined forces in a blistering amicus brief devoted entirely to the Eggemeyer court's odd notion of substantive due process. See Brief of Amici Curiae, Campbell v. Campbell, 613 S.W.2d 236 (Tex. 1980). The best that Professor Sampson has ever been able to say for Eggemeyer's due process argument is that "[o]ne must give Justice Pope kudos for candor in his approach, if for nothing else." Sampson, supra note 130, at 1338 n.180. 
opinion "is not easily comprehended."286 Although the Texas Supreme Court took its cue from the United States Supreme Court, the notion of substantive due process had long since been discredited in that forum. ${ }^{287}$ Moreover, the Texas court's amazing assumption that no public benefit could result from permitting divestiture of separate property in a divorce defies both precedent and common sense. Marriage and divorce have long been subjects of great public concern, ${ }^{288}$ and the state has a clear interest in (at the very least) preventing ex-spouses from burdening the welfare rolls. ${ }^{289}$ As early as Fitts, the Texas Supreme Court inferred that "no construction can be put upon the [property division] Statute, which would authorize the Court, in any case, to do less than provide a maintenance for the wife, if the estate of the husband be sufficient for that purpose." 290 Eggemeyer, however, sacrifices both equity and history to protect property.

All things considered, Eggemeyer is a disastrous failure of judicial analysis. The court failed to address the reasoning of Fitts and more than a century of authority built on principles first set out in Fitts. The magnitude of this failure cannot be overstated. Fitts was something more than a quaint relic of Texas' unsophisticated frontier days, gathering dust on lawyers' shelves. When Chief Justice John Hemphill spoke in Fitts of the Alabama origins of the Texas property division statute, he spoke with the authority of a court that counted among its members the long-time chief justice of the Alabama Supreme Court. ${ }^{291}$ When Hemphill approved the award of separate personalty with no

286. McKnight, supra, note 41, at 93, 137.

287. Eggemeyer relies on Thompson v. Consolidated Gas Util. Corp., as imported into Texas law in a 1944 decision. See Eggemeyer, 554 S.W.2d at 140-41. In a decision issued one month after Thompson, however, the United States Supreme Court began a rapid retreat from the substantive due process doctrine. See West Coast Hotel Co. v. Parrish, 300 U.S. 379 (1937); LAURENCE H. TRIBE, AMERICAN CONSTITUTIONAL LAW § 8-7, at 581-82 (2d ed., 1988 ). Several years before Eggemeyer, the United States Supreme Court characterized Thompson and similar opinions as a "vintage of decisions which exalted substantive due process by striking down state legislation which a majority of the Court deemed unwise." North Dakota State Bd. of Pharmacy v. Snyder's Drug Stores, Inc., 414 U.S. 156, 164 (1973).

288. One of the earliest expressions of this principle in Texas law is found in Sheffield $v$. Sheffield, 3 Tex. 79 (1848). Justifying legislative restrictions on dissolution of the marriage contract, Chief Justice Hemphill noted that "the relations, duties, obligations and consequences flowing from the contract are so important to the peace and welfare of society, as to have placed it under the control of special municipal regulations, independent of the will of the parties." Id. at 86 . Hemphill gave this policy practical effect by denying Mr. Sheffield a divorce, observing with his typical candor:

Half the marriages in the country might be dissolved if occasional freaks of temper, or even the direful necessity of a husband's mending his own coat for once in his life, were in legal contemplation such ill treatment as would thoroughly embitter the fountains of matrimonial Id. at 87.

felicity, and render its waters a nauseous and insupportable draught.

289. In Orr v. Orr, 440 U.S. 268,280 (1979), while invalidating sex-based alimony as a denial of equal protection, the United States Supreme Court commented, "We concede, of course, that assisting needy spouses is a legitimate and important governmental objective."

290. Fitts, 14 Tex. at 451 . In the quoted language, the Court was summarizing Lovett v. Lovett, 11 Ala 763 (1847), a case felt to have "peculiar application and force" to the statutory analysis required to decide Fitts, 14 Tex. at 451.

291. Abner S. Lipscomb served as chief justice of the Alabama Supreme Court from 1823 to 1835. He emigrated to Texas in 1839 and was appointed an associate justice of the Texas Supreme Court in 1846. 2 HANDBOOK OF TEXAS, supra note 15, at 61-62. 
constitutional qualms, he spoke not only as chief justice, but as a committee chairman for the constitutional convention, and as an active participant in the drafting of the very constitutional language that the court in Eggemeyer later viewed as requiring a contrary result. ${ }^{292}$

Predictably, Eggemeyer did not settle the issue. Some courts and commentators simply could not believe that the Texas Supreme Court actually meant what it had said. ${ }^{293}$ In one such decision, Campbell v. Campbell, the Fort Worth Court of Civil Appeals ignored Eggemeyer and awarded the wife a half-interest in $\$ 1.2$ million of the husband's promissory notes, reasoning that all of the Eggemeyer court's comments on personal property were dicta. ${ }^{294}$ The Texas Supreme Court granted an application for writ of error in Campbell and, in 1980, issued an opinion extending Eggemeyer's holding to personalty, with three of the court's nine justices dissenting and one not participating. ${ }^{295}$ The opinion's author (who, ironically, also wrote the Eggemeyer dissent) implied that his decision was reached more on the basis of stare decisis than on any fundamental change of heart. ${ }^{296}$

If ever a case was "soft law," Campbell was that case. A change of one vote on rehearing would have changed the result and, as the months that the decision remained on rehearing dragged on, the winning party elected to settle. The court withdrew the opinion in the process of dismissing the motion for rehearing. In retrospect, Mr. Campbell's decision to settle was wise. After his retirement, the author of the Campbell dissent stated that he was in the process of rewriting his dissent as the majority opinion when the settlement was announced. ${ }^{297}$

The last word on the subject to date came in Cameron v. Cameron, ${ }^{298}$ a 1982 case involving savings bonds. The bonds were acquired by the husband, apparently while he resided in a common law state. The Texas Supreme Court, by judicial analogy to a new Texas statute providing for division of "quasicommunity property,"299 held that the savings bonds could be awarded to the

292. John Hemphill championed the matrimonial property provision of the Texas Constitution. RosaleE MORRIS CURTIS, JoHN HEMPHILl, FIRST CHIEF JUSTICE OF THE STATE OF TEXAS 53 (1971); see also McKnight, supra note 44, at 72 (describing Hemphill's active participation in constitutional debate over that provision).

293. See, e.g., York v. York, 579 S.W.2d 24, 25 (Tex. Civ. App.-Beaumont 1979, no writ) ("Eggemeyer] did not change the rule permitting divestiture of personalty upon the granting of the divorce.") (emphasis in original); Muns v. Muns, 567 S.W.2d 563, 565 (Tex. Civ. App.-Dallas 1978, no writ) ("Although some of the court's reasoning ... would seem to apply also to separate personal property, the court did not mention the different treatment historically given to separate personal property.").

294. 586 S.W.2d 162 (Tex. Civ. App.-Fort Worth 1979, writ granted, dism'd by agr.).

295. Campbell v. Campbell, 23 Tex. Sup. Ct. J. 391 (June 4, 1980), withdrawn, 613 S.W.2d 236 (Tex. 1980).

296. See id. at 392 n.2, 393.

297. Chief Justice Joe R. Greenhill, Remarks at the Southern Methodist University School of Law, Symposium on Texas Law: Its Development and Reform from 1836 to 1936, at 30 (Oct. 17, 1986) (transcipt on file with the author).

298. 641 S.W.2d 210 (Tex. 1982).

299. The statute provides that a divorce court may divide property acquired during marriage while the spouses were domiciled in a common law state as if the property has been acquired while the spouses 
wife. In extensive dicta, however, vigorously disavowed by four concurring justices, ${ }^{300}$ the court confirmed and expanded on its Eggemeyer dicta prohibiting the divestiture of separate personalty.

While most of Justice Pope's argument for the Cameron majority was merely an attempt to bolster his earlier reasoning in Eggemeyer, ${ }^{301}$ two new twists in the reasoning appeared. First, it is argued in Cameron that a nondivestiture rule for separate property would bring Texas into conformance with the majority rule of community property jurisdictions. ${ }^{302}$ The opinion, however, glosses over differences between Texas law and that of other jurisdictions, ${ }^{303}$ including the fact that every other community property state permits permanent alimony. ${ }^{304}$ The court thus preferred interstate uniformity over equitable results.

Second, Cameron intertwines the Texas "public policy" against alimony with its holding, suggesting that separate property cannot be divided because "[d]ivestiture of separate property for reason of financial support is nothing less than alimony." ${ }^{305}$ This ruling completed a 180-degree turn from the Fitts reasoning, in which the court suggested that separate property could be used whenever necessary to enable the wife, "if her husband's estate were such as to justify it, to live in such a manner as that, if possible, she may regain her lost standing in society" ${ }^{306}$ - a result more generous by far than most modern alimony awards.

Eggemeyer and Cameron have broad implications for the future of Texas community property law. Indeed, in the decade or more since these legal bombshells, the theoretical dust still has not settled. The reasoning of the decisions has called much Texas divorce law into question. For example, if it is no longer possible to "divest" separate property, and if that prohibition has constitutional dimensions, then it may not be appropriate to grant life interests in separate real estate ${ }^{307}$ or to place separate property in trust for the nonown-

had been domiciled in Texas. See TeX. FAM. Code ANN. § 3.63(b)(1)-(2) (West Supp. 1992).

300. Cameron, 641 S.W.2d at 223 (McGee, J., concurring); id. at 228 (Greenhill, C.J., concurring).

301. The language has been described as "a lengthy and completely unnecessary apology for Eggemeyer." Oliver S. Heard, Jr., Recent Decisions of the Texas Supreme Court in the Field of Family Law B-3, STATE Bar of TeXas, MARRIAGe Dissolution (1984).

302. Cameron, 641 S.W.2d at 216-18.

303. As but one example, Cameron cites Arizona law as supporting its conclusion that "estate of the parties" means only community property, id. at $214 \mathrm{n} .2$, yet does not mention the fact that the Arizona statute contains relevant additional language, not present in the Texas statute. See Collier v. Collier, 242 P.2d 537, 541 (Ariz. 1952) (citing statutory language providing that a court could "however" fix a lien on separate property, which, by implication, denies the power to divest).

304. The opinion mentions this fact, Cameron, 641 S.W.2d at 218 n.7, and even concedes that several community property jurisdictions permit divestiture for spousal support, id. at 217 , yet still contends that the result "puts Texas in conformity with the law in six of the seven other community property states." Id. at 216. Justice McGee's concurring opinion criticizes the majority's failure to focus on the availability of alimony in other jurisdictions as "a critical distinction which the majority relegates to a footnote." Id. at 228 (McGee, J., concurring).

305. Id. at 219.

306. Fitts v. Fitts, 14 Tex. 443, 451 (Tex. 1855) (summarizing Lovett v. Lovett, 11 Ala. 763 (1847)).

307. In Eggemeyer, the court discussed Hedtke v. Hedtke, a 1923 decision awarding the wife a life interest in the homestead, her husband's separately-owned real estate. See Eggemeyer, 554 S.W.2d at 141. The Court stated that the language in Hedtke was "overbroad," and stated (incorrectly) that Hedtke 
er spouse. ${ }^{308}$ Because community ownership is viewed as an equal cotenan$\mathrm{cy}^{309}$ any unequal division of community property at divorce would seem, logically, to be prohibited. ${ }^{310}$ While neither Eggemeyer nor Cameron go so far, neither opinion contains any basis for a principled distinction that would prevent such extensions. Eggemeyer, Cameron, and "no fault" divorce also have combined to place great pressure on divorce courts in matters of property characterization and division. As a result, some issues of little consequence in other jurisdictions have taken on economic life-or-death dimensions in Texas divorces. For example, reimbursement doctrine has now become a "hot" theoretical topic ${ }^{311}$ and, perhaps as a touch of poetic justice, a continuing thorn in the side of the Texas Supreme Court. ${ }^{312}$

What does one make of the Texas Supreme Court's abrupt about-face on community property doctrine in Eggemeyer, Campbell, and Cameron? It is tempting to view these decisions as a reaction by a conservative judiciary to the women's movement of the $1960 \mathrm{~s}$, much as the restrictive decisions of the $1920 \mathrm{~s}$ and 1930s could be seen as a backlash against the women's suffrage movement. ${ }^{313}$ The decisions rely explicitly on the restrictive constitutional rulings of $1925,,^{314}$ and the sole female member of the court during the period, Justice

was a child support case, leaving one with the impression that Hedtke might have been disapproved to the extent that it granted the ex-wife an interest in the homestead for any longer than the children's minority. Id. Professor McKnight agrees. See McKnight, supra note 41, at 109, 124.

308. This problem was noted in the Campbell dissent. See Campbell v. Campbell, 613 S.W.2d 236, 242 (Tex. 1980) (Greenhill, C.J., dissenting).

309. See, e.g., Busby v. Busby, 457 S.W.2d 551, 554 (Tex. 1970).

310. In Hailey v. Hailey, 331 S.W.2d 299 (Tex. 1960), the Texas Supreme Court settled a longstanding dispute, ruling that an unequal award of title to community-owned real estate was permitted. Eggemeyer and Cameron approved Hailey. See Eggemeyer, 554 S.W.2d; Cameron, 641 S.W.2d at 215. Yet, if the Texas Constitution prohibits divestiture of title, it is difficult to see how a cotenancy can become $100 \%$ ownership by one spouse without some divestiture taking place somewhere. If Eggemeyer is correct, the trial court's statutory discretion to make unequal awards of community property is constitutionally suspect. A similar argument is found in the Campbell dissent, 23 Tex. Sup. Ct. J. at 397 (Greenhill, C.J., dissenting), and in Dean Castleberry's commentary on Eggemeyer, Castleberry, supra note 265, at 51. See also Mendoza v. Mendoza, 621 S.W.2d 420, 423 (Tex. Civ. App.-San Antonio 1981, no writ).

311. As Professor Eugene L. Smith puts it,

I don't believe it is coincidental that the limitations on courts' powers imposed by Eggemeyer in 1977 mark the starting point of the courts' and lawyers' greater utilization of the "doctrine" of reimbursement in divorce cases to achieve a "just" or "fair" division of property in instances in which the community estate is minimal.

Eugene L. Smith, Reimbursement, STATE BAR OF TEXaS, AdvancEd FAMily LAw CouRSE C-1 (1982). Of the 54 articles listed under the topic of "reimbursement" in a recent 22-year index of Texas law, all but one were written after Eggemeyer. See 72-73 JOHN J. SAMPSON \& CATHY MEDINA, INDEX TO Legal Publications, Texas Family LAw 1970-92 (State Bar of Texas, 1991) (State Bar Section Report, Family Law).

312. The Texas Supreme Court's struggle to devise a coherent legal standard for reimbursement gave rise to Jensen v. Jensen, 665 S.W.2d 107 (1984), a case that generated two withdrawn opinions before a final result was reached, and is described by some practitioners as the only case in Texas history in which it took the Texas Supreme Court three tries to "get it wrong." See generally James W. Paulsen, Jensen III and Beyond: Exploring the Community Property Aspects of Closely Held Corporate Stock in Texas, 37 BAYLOR L. REV. 653 (1985).

313. See supra notes 163-64 and accompanying text.

314. Cameron, 641 S.W.2d at 213; Eggemeyer, 554 S.W.2d at 140. 
Ruby Sondock, voted against the Cameron dicta. ${ }^{315}$ One commentator, criticizing contemporaneous community property decisions on reimbursement issues, has raised the possibility of just such a gender bias. ${ }^{316}$

There is a somewhat kinder explanation. The Texas Supreme Court's lack of general jurisdiction over divorce cases, coupled with the low prestige of family law practice, created a supreme court with little exposure to divorce cases and little prior expertise in family law. At the time of Cameron, for example, only one of the court's nine members, Justice Sondock, had any substantial experience as a family law judge. For a bench whose members' expertise and daily workload centers on assuring certainty of title, interpreting contract terms and the like, a community property system in which personal property can be divested but real estate cannot, in which a life estate or trust is not a "divestiture," and in which a trial court's discretion reigns supreme, is not likely to receive a very sympathetic hearing. ${ }^{317}$ With its members insulated in their judicial functions from the human tragedy of divorce that a trial judge must witness on a daily basis, ${ }^{318}$ the tendency of the Texas Supreme Court to favor stability over equity and to misread some fairly esoteric case law in the process can perhaps be understood, though not excused. ${ }^{319}$

315. Cameron, 641 S.W.2d at 228 (McGee, J., concurring).

316. See Bea Ann Smith, The Partnership Theory of Marriage: A Borrowed Solution Fails, 68 TEX. L. REv. 689, 716 (1990). If such a bias does exist, Professor Smith certainly is taking the lead in rectifying the situation. She has recently accepted an appointment to the Austin Court of Appeals. Professor Smith's article criticizes Cameron and Eggemeyer as examples of "blind adherence to community-property principles" at the expense of the economically dependent spouse. Id. at 731 . The author of this article would disagree; Cameron and Eggemeyer are clear departures from community property principles as they have existed in Texas since Fitts.

317. Even Chief Justice Hemphill, in setting out the rules in Fitts, admitted that his reading was not "the most obvious construction of the statute." 14 Tex. at 450. The faults in the Eggemeyer ruling stem as much from an attempt to impose a logical reading on a slightly illogical statute as from any other failing. Justice Holmes once remarked that "a page of history is worth a volume of logic." New York Trust Co. v. Eisner, 256 U.S. 345, 349 (1921). In Eggemeyer, however, many pages of Texas legal history were removed from the law books in the court's attempt to achieve a logical result.

318. This is not meant as hyperbole. Judge Dan Gibbs of Dallas County, for example, has stated:

I have sat on these cases for sixteen years now and have watched the progression of the limitation of the division of property, Eggemeyer, Cameron, McCarty, so forth. The week before last, $I$ heard a case where the children were in college. ... The wife was going to get an interest in the home and furnishings. Out of the job market for over thirty years, no experience, no income. These type of cases we hear frequently and just cry over them.

Hearings on Tex. S.B. 537 Before the Subcomm. on Civil Matters of Sen. Jur. Comm. 68th Leg. (April 25,1983 ) (tape on file with the author).

319. When the Texas Supreme Court addressed some of the same questions in Hedtke v. Hedtke, 248 S.W. 21 (Tex. 1923), it had no greater expertise in family law, less sophisticated research facilities, and no assistance whatever from amicus briefs. The court nonetheless interpreted Fitts correctly and awarded the wife a life interest in the husband's separate property homestead. Id. at 22-23. In Eggemeyer, the Texas Supreme Court "distinguished" Hedtke because children were involved in the former case. See 554 S.W.2d at 141 (characterizing Hedtke's language regarding obligations to divorced wife, as opposed to children, as "overbroad"). The Eggemeyer dissent persuasively criticized this reading. See 554 S.W.2d at 143 (Steakley, J., dissenting).

An examination of the Hedike briefs confirms the fact that child support had nothing to do with the decision. In fact, contrary to the Eggemeyer court's reading, the focus of Hedtke could not have been child support because the husband's briefs conceded any child support issues. Appellant's [Husband's] Brief at 8, Hedtke v. Hedtke, 248 S.W. 21 states the following: 
If part of the explanation for Eggemeyer does lie in a lack of judicial sensitivity and expertise, there may be some hope for the future. In 1987, the state legislature granted the Texas Supreme Court full jurisdiction over divorce cases. ${ }^{320}$ All judges who decided Eggemeyer and Cameron have now retired. Some future reexamination of Eggemeyer, with a more rational result, might not, therefore, be out of the question. In the interim, however, most attention has focused on the legislative arena.

\section{Legislative Efforts}

From the mid-1920s to the present, scholarly commentators have repeatedly urged the Texas Legislature to enact some form of alimony statute. ${ }^{321}$ When the Texas Supreme Court reaches a particularly inequitable result in a divorce case, judges typically will join in the chorus. ${ }^{322}$ And in fact, one or more bills calling for some form of alimony-or the politically more palatable terms "spousal maintenance" or "readjustment allowance" ${ }^{323}$-have been introduced

[The statute] in our opinion, refers to and contemplates only the community property ... and by no process of reasoning could be extended to the separate estate of either one of them. We concede that the court may enter orders affecting the separate property of either spouse for the benefit of the children of their marriage, but not for the benefit of either spouse.

See Appellee's [Wife's] Brief at 7 (responding to husband's brief on point, concluding that "whatever may have been the process of reasoning [in Fitts], the Supreme Court of this State has reached a different conclusion in its construction of this Statute").

320. Tex. S.B. 841, 70th Leg., R.S. (1106) (1987) (amending $\$ 22.225$ of the Texas Government Code); see also generally James W. Paulsen, Recent Changes in Texas Supreme Court Jurisdiction at 3, State Bar of Texas, Thirteenth Annual Advanced Family Law Course (Aug. 18, 1987).

321. See, e.g., Cox, supra note 170, at 351 (stating that "[a]ll the argument favoring an award of support to the wife after divorce can be directed with much better effect to the legislature for the purpose of securing a permanent alimony statute"); Atlas, supra note 190, at 366 (proposing in 1951 that "we should provide for permanent alimony in order to cover every conceivable situation," since "[i]t would at least be more realistic than our present policy"); Robert B. Evans, Comment, Substitutes for Alimony: A Review of Methods for Providing Periodic Support Payments Subsequent to Divorce, 20 BAYLOR L. REV. 314, 324 (1968) (noting that judicial devices are "cumbersome and inflexible," but adding that, "whatever their shortcomings, these substitutes for alimony are a part of the law and they will remain and continue to be used until replaced by legislation"); Byron P. Davis, Comment, Permanent Alimony-Disguised in Property Settlement Agreements, 11 S. TEX. L.J. 269, 278 (1970) (suggesting that "new legislation allowing permanent alimony in absolute divorce cases would eliminate the practice of employing ... . devious methods for obtaining the same result as found in property settlement agreements"); Turley, supra note 237, at 56 (recommending that the Texas Supreme Court tell the legislature that "the time is ripe for a change"); Judith K. Guthrie \& John J. Sampson, Spousal Maintenance, 48 TEX. B. J. 298, 299 (1985) (stating that "[t]he proposed spousal maintenance bill . . . is simple and fair, and its adoption is sincerely urged").

322. See, e.g., Cameron v. Cameron, 641 S.W.2d 210, 228-29 (Tex. 1982) (Greenhill, C.J., concurring) (stating that the legislature may wish to consider legislation clarifying the status of separate property as "an alternative to enacting alimony statutes which will surely result if the 'due process' dictum of Eggemeyer should ultimately prevail"); Eichelberger v. Eichelberger, 582 S.W.2d 395, 403 (Tex. 1979) (noting that the possible adoption of alimony is "a legislative, not a judicial function, and may require constitutional amendments which are the responsibility of the Legislature").

323. As one commentator put it, alimony is "a word most Texas lawmakers wouldn't be caught uttering in their sleep, much less on floors of their respective houses in the Legislature." Rosanne Mogavero, Texas Takes a Look at Alimony, THIRD COAST, Jan. 1983, at 28; see also Hearings on Tex. S.B. 532 Before the House Judiciary Comm., 70th Leg., R.S. (630) (Apr. 27, 1987) (statement of John J. Sampson) ("The word 'alimony' does raise the hackles on the backs of people's necks-especially male 
at every two-year term of the Texas Legislature since $1971 .{ }^{324}$ To date, not one has passed.

The reason for the legislature's failure to pass an alimony bill is simple. As stated by a media report, "There is widespread agreement that behind the antialimony attitude is a knee-jerk male response." 325 Unfortunately, this is not mere journalistic hyperbole. Rather, an examination of more formal legislative sources substantiates the role of gender bias. To the author's knowledge, no Texas alimony bill has encountered any significant formal opposition, and no bill has been voted down on the merits on the floor of either house of the state legislature. Nonetheless, session after session, spousal maintenance bills are proposed but do not pass. The details vary, but the underlying cause does not.

In 1983, the first session after the Cameron decision, ${ }^{326}$ a spousal support bill died in a senate committee, despite the fact that not a single witness testified against it. The legislative history contains a remarkably clear record of a genderbiased vote. ${ }^{327}$ As one senator later remarked, "There is greater identification [for this issue] with males who might be required to pay." 328 The 1983 bill was probably doomed to fail. It enjoyed only lukewarm support from the state bar $^{329}$ and the Texas Women's Political Caucus failed to support the bill formally, ${ }^{330}$ a fact gleefully pointed out by its opponents.

At the next session, an extraordinarily limited bill, this time endorsed by the state bar's board of directors ${ }^{331}$ and the Texas Family Law Council, ${ }^{332}$ was

necks."); Kuehler, supra note 241, at 19 ("Just mentioning the word [alimony] makes lawmakers squeamish."). Senator Santiesteban, introducing the 1977 bill, began his testimony: "This is a little noncontroversial bill that creates in Texas what I call a 'readjustment allowance.' Some people may call it 'alimony." Hearings on Tex. S.B. 452, supra note 242 (statement of Sen. H. Tati Santiesteban) (tape on file with the author).

324. In 1971 and 1973, spousal maintenance was considered as part of general revisions to the Family Code. See Hearings on Tex. S.B. 452, supra note 242 (statement of Sen. H. Tati Santiesteban) (tape on file with the author). A separate bill was also introduced in 1973. See Tex. H.B. 640, 63d Leg., C.S. (1973). Other bills are discussed in text. The author's review of legislation is not comprehensive, in part because legislative records leave something to be desired. There may well have been other, earlier bills. Prominent family law attorney Louise Raggio, who has described herself as "sort of a historical monument" to spousal support proposals, says, "I think I've been testifying on this since '67 or '69." Hearings on Tex. S.B. 452, supra note 242 (tape on file with the author).

325. Kuehler, supra note 241 , at 21.

326. Cameron, 641 S.W.2d 210.

327. Responding to the sponsor's statement that the bill was extremely limited in scope, the committee chair responded that the bill "only applies to divorced people ... and men." The sponsor jokingly commented that an amendment to exempt current legislators would be acceptable, and another senator commented that the vote would be a referendum on which members of the committee had "confidence in their marriage." The bill failed, six to five. Meeting of the Sen. Jur. Comm. on Tex. S.B. 537, 68th Leg., R.S. (162) (May 17, 1983) (tape on file with the author).

328. Kuehler, supra note 241 , at 21 .

329. It was reported that the state bar's board of directors, almost all male, "got a lot of heat from lawyers ... who did not want alimony used against them" and finally decided to support only "the concept of alimony." Id. at 20.

330. The TWPC's lobbyist expressed her conviction that alimony "won't pass in the 20th century" so "we ... go with those [bills] that have a reasonable chance of success." Id.

331. Hearings on Tex. S.B. 547 Before the Sen. Health and Human Resources Comm., 69th Leg., R.S. (Apr. 22, 1985) (testimony of Judith Guthrie) (tape on file with the author).

332. Id. (testimony of John J. Sampson). 
presented. The Texas Women's Political Caucus did not repeat its mistake, as two TWPC representatives testified in favor of the bill. Their testimony was well-received, although they were also regaled with good-humored stories of senators' own divorces. ${ }^{333}$ The bill was reported favorably from committee, passed the senate by a wide margin but died in the house..$^{334}$

This 1985 bill was to set a pattern. Successive spousal support proposals have been approved by the state senate with monotonous regularity and by lopsided margins, ${ }^{335}$ only to die for some procedural reason in the house. ${ }^{336}$ The 1987 bill had a better chance than most; supporters secured a former house opponent as a sponsor, ${ }^{337}$ and an American Bar Association symposium on alimony and child support was held in Austin, timed to coincide with the legislative session. $^{338}$ Nonetheless, the bill died in the Texas House of Representatives. As a key lawmaker later explained, "many members [of the House], who have experienced divorce or know friends who have, fear the almost uninhibited power of divorce judges." 339

By 1989 , editorials in major Texas newspapers called prior legislative inaction "disgraceful" 340 and urged the house to "quit ducking the subject." 341 A 1989

333. Id.

334. Representative Robert Bush of the House Judiciary Committee was quoted as saying: "A lot of people think it's all downhill now that we got the alimony bill out of the Senate. . . This [negative procedural floor] vote shows people who support it have still got a lot of work to do." Texas House Approves Child Abuse Measure, UPI (May 7, 1985) (LEXIS, NEXIS Library, UPI File).

335. A colloquoy between Professor John J. Sampson and the committee chair during 1989 hearings aptly summarized the situation:

Sampson: The history, of course, is that the senate has passed this bill on past occasions, the votes usually in the twenty-five to five range, never more than five votes in opposition. The house has obviously not passed the bill, as of yet.

Chair: You know what that means is that we ordinarily don't have more than five members a session going through a divorce. But go ahead.

Hearings on Tex. S.B. 330 before the Sen. Jur. Comm., 71st Leg., R.S. (827) (Apr. 4, 1989) (tape on file with author).

336. As stated in 1989 senate hearings:

Sen. Caperton: [This bill] is so narrow, Members, that . . . as one rather conservative house member told me last week, he said "If anybody reads the bill, I don't know how they can be against it."

Chair: But they always have.

Sen. Caperton: But they have always found a way.

Chair: They have always found a way.

Sen Krier: You know, they may have been against it. We don't know that they read the bill.

Id.

337. Spousal Maintenance Bill Status Report, STATE BAR SECTION REPORT: WOMEN AND THE LAW, Mar. 1987, at 1.

338. National Symposium on Alimony and Child Support, in id. at 1.

339. Laylan Copelin, Bill Seeks to Assist Ex-Spouses: It's Not Alimony, Lawmakers Insist, AUSTIN AM.-STATESMAN, Apr. 29, 1991, at B2 (quoting Mike Toomey, the former chair of the House Judiciary Committee).

340. Carefully Drawn Bill Deserves House's Approval, Dallas MORNING NEws, Apr. 24, 1989, at 27. The alimony issue has been around in Texas so long that newspapers are evidently recycling their supportive editorials. The same newspaper also called legislative action "disgraceful" during the 1987 session. See Spousal Maintenance Bill Status Report, STATE BAR SECTION REPORT: WOMEN AND THE 
bill nearly made it to a vote on the house floor, despite opposition by a subcommittee chair, ${ }^{342}$ failing on a point of order because the wrong bill history had been stapled to the bill..$^{343}$ The maneuver fooled no one. ${ }^{344}$ One principal proponent simply attributed the action to a "barbaric macho" mentality on the part of house members. ${ }^{345}$ In 1991, the legislature adjourned with a spousal support bill passed by the senate, favorably reported out of a house committee, yet somehow simply not acted upon by the full house. ${ }^{346}$ The story of the 1993 session, to date, is the same. . $^{347}$

This record of legislative footdragging is even more remarkable when viewed against a backdrop of the severely restrictive and progressively more limited nature of the legislative proposals in question. The 1983 bill, for example, required a marriage of at least five years' duration before any postdivorce support could be awarded. ${ }^{348}$ The 1985 proposal upped this threshold to a tenyear marriage and generally would have "capped" support at a maximum of $\$ 1500$ per month (or $20 \%$ of average gross income) for three years, or until remarriage. ${ }^{349}$ The 1993 proposal kept all these restrictions, added a requirement that the recipient "clearly [] lack earning ability in the labor market adequate to provide support for the spouse's minimum reasonable needs," and provided that support would also terminate on proof of cohabitation "on a continuing, conjugal basis." 350 In light of this trend, one might reasonably question whether, if a support bill ever should be adopted in Texas, it will be so narrowly drawn as to have virtually no effect.

LAw, Mar. 1987, at 1.

341. Limited Alimony: House Should Enact Law With Adequate Safeguards, HoUSTON POST, Apr. 25,1989 , at A-18.

342. The vote prompted a remark by another committee member: "Chairman ...., I'm sorry to see you're having trouble at home, sir." Proceedings on Tex. S.B. 697 before the House Subcomm. on Spousal Maintenance, 71st Leg., R.S. (856) (April 19, 1989) (tape on file with author).

343. Teri Clausing, Texas House Passes Pickup Bill; Kills Alimony Proposal, UPI ( May 26, 1989) (LEXIS, NEXIS Library, UPI file).

344. Several very technical points of order were raised on the house floor in order to avoid a vote on the merits, an unusual procedure which prompted the chair to comment, "I take it nobody likes this bill, huh?" A sarcastic voice from the floor replied, "Roll call." Proceedings on Tex. S.B. 330 on the Floor of the House, 71st Leg., R.S. (827) (May 25, 1989) (tape on file with the author). $1,8$.

345. Walter Borges \& Robert Elder, Jr., Requiem for a Lone Lobbyist, TEX. LAw., June 5, 1989, at

346. See Tex. S.B. 90, 72d Leg., R.S. (1991). The bill was reported favorably out of the House Judicial Affairs Committee-on a unanimous vote-with about six weeks remaining in the session, but was not scheduled for debate by the House Calendar Committee. Telephone interview with David Mintz, legislative assistant to Sen. Eddie Bernice Johnson (Apr. 14, 1992).

347. As this article went to press, the Texas Senate had, once again, passed an alimony bill and, once again, the measure was stalled in the House Calendars Committee. Robert Elder, Jr., Remember the Alimony, TEX. LAw, Mar. 29, 1993, at 4. In a critical "procedural" vote, the House Calendars Committee decided not to schedule the alimony bill for consideration by the full House. The committee split seven to one on the issue, with the committee's sole female member casting the dissenting vote. Alimony Bill Off Agenda, Hous. CHRONiCle, Apr. 16, 1993, at 29A.

348. Tex. S.B. 537, 68th Leg., R.S. (1983).

349. Sen. Comm. on Health \& Hum. Res., Bill Analysis for S.B. 547 As Amended, 70th Leg., R.S. (1987).

350. C.S.S.B. 33, 73d Leg., R.S. (1993). 
INTO THE Future: THE PROSPECTS FOR SPOUSAL SUPPORT IN TEXAS

\section{A. Permanent Alimony and Public Policy}

While courts have declared judicially ordered alimony in Texas to be against the state's public policy, the decisions contain very little discussion of the precise nature of this public policy. Alimony has a bad name in some quarters, so much so that efforts at legislative reform in Texas are consistently framed as "spousal maintenance" bills. In part, the instinctive negative reaction of some legislators to the word "alimony" is a result of the tendency of the news media to report large alimony awards, often involving Hollywood celebrities. ${ }^{351}$ Surely, alimony can be abused, as can the discretionary division of property. The solution, however, would be a narrowly drafted alimony statute-such as the ones that are regularly presented before the Texas Legislature ${ }^{352}$-or meaningful appellate review.

Some arguments against alimony, however, do have a more plausible basis. One long-standing problem is that permanent alimony has never had a very clear legal pedigree. Early U.S. courts and legislatures seem to have combined the notion of continuing spousal support after permanent separation-that is, support after a divorce a mensa et thoro, granted by English ecclesiastical courts-with Parliament's authority to grant permanent divorces. ${ }^{353}$ The view that alimony derives from one spouse's duty to support the other thus collides with the opposing view that permanent divorce extinguishes all marital rights and duties. ${ }^{354}$ While most opponents of alimony in Texas are blissfully ignorant of these historical nuances, the argument that alimony is "like making payments on a car that's been wrecked" 355 conveys much the same idea. Even if one were to grant that the duty of support per se should end at divorce, other good reasons might exist for an award of alimony, such as the justified expectations

351. As a perceptive Texas legislative report put it: "Contrary to popular myth, the 'Johnny Carson' type of divorce and alimony award was and is extremely rare, though, naturally, they tend to receive an inordinate amount of publicity and attention." See Texas House Judiciary Report, supra note 243, at 59; see also Hearings on Tex. S.B. 532 Before the House Jud. Comm., 70th Leg. (Apr. 27, 1987) (testimony of John J. Sampson) ("Alimony gets this bad reputation because of Hollywood. And if we didn't have California, if we didn't have Hollywood, it wouldn't be quite so bad.").

352. The perennial Texas alimony bill, varying little from session to session, is extraordinarily limited in amount and duration. See generally Guthrie \& Sampson, supra note 321, at 298.

353. See ClARK, supra note $18, \S 16.1$, at $619-20$.

354. Professor McKnight describes alimony in the United States as "an adaptation of an ecclesiastical institution that had lost touch with its rational basis, that is, the provision for continued support during marriage." McKnight, supra note 267, at 127.

355. Florence Hamlish Levinsohn, Breaking $U p$ is Still Hard to Do, ChICAGo TRIB. SUNDA Y MAG., Oct. 21, 1991, at 16 (quoting Houston attorney Donn Fullenweider, summarizing Texas views) (internal quotation marks omitted). 
of a spouse who has made lifelong contributions to a marriage with reasonable expectation of some return on the marital investment. ${ }^{356}$

Another argument against permanent alimony commonly encountered in Texas is that property division is a better way of accomplishing the same result. ${ }^{357}$ As demonstrated, there was once some historical support for this argument. ${ }^{358}$ The strength of this argument has eroded over time, however, as wages and earning capacity have replaced landholding as the primary source of family wealth. ${ }^{359}$ Moreover, in view of the fact that every other community property state has both property division and alimony, the argument that one substitutes for the other is without merit. ${ }^{360}$

A third, and more modern, objection to alimony is that the changing makeup of the typical family no longer justifies the view of alimony as a method of support for a helpless ex-spouse. ${ }^{361}$ While two-career marriages may indeed reduce the need for long-term alimony, a large number of marriages are still "traditional."362 Moreover, even in "new model" two-career marriages, persuasive statistical evidence suggests that couples still often place the husband's career ahead of the wife's. ${ }^{363}$ As long as this is true in any substantial number

356. Professor Sampson put it during one of his biennial appearances before the Texas Legislature: We're talking about the circumstances in which parties have agreed to live their lives in a certain way, under certain rules and conditions. One of them has detrimentally relied on the continuation of the deal, and the deal has somehow fallen through-the deal in this circumstance being that one of the parties, almost invariably the wife, will sacrifice development of the career ... for the good of the community.

Hearings on Tex. S. B. 330 Before the Sen. Jur. Comm., 71st Leg., R.S. (Apr. 4, 1989) (testimony of Prof. John J. Sampson) (tape on file with the author).

357. This attitude is reflected in the case law, as well as in reports generated by the news media. See, e.g., Cameron v. Cameron, 641 S.W.2d 210, 218 (Tex. 1982) (referring to the fact that "spouses share the gains of their marriage equally under our community property legacy from Spain"); Pape v. Pape, 35 S.W. 479, 480 (Tex. Viv. App. 1896) (stating that "[a]mple provision is made in the statutes of this state for the support of the wife by the provision for the division of the property"); Gary Taylor, The Eyes of Texas are on Alimony, NAT'L L.J., Apr. 27, 1987, at 3 ("Historically, Texas has relied on its strong community property provisions to balance inequities that occur when a high earner divorces a spouse who makes little or no income"); Poverty, Hopelessness Often the Result of Divorce for Texas Women, Southwest Newswire Inc., Apr. 15, 1987 ("Historically, Texas attitudes have been influenced by an oiland land-rich economy .....").

358. See supra part III.B.

359. Accord Turley, supra note 237, at 6; see also, e.g., Kuehler, supra note 241, at 21 ("Even critics say [division of community property] worked fine in earlier days when Texas families owned farms and ranches that were easily split in half. But today's married couple doesn't possess much more than credit cards and mortgages and, generally, little property. The most valuable asset may be education or earning potential."). Id.

360. See, e.g., Cameron, 641 S.W.2d at 218 (stating that alimony is denied because "spouses share the gains of their marriage equally under our community property legacy from Spain").

361. As one Texas observer has stated: "Society and the law no longer presume that women as a class become unemployable as the result of marriage or motherhood; instead, today's presumption is that a woman at divorce should continue, resume, or establish financial independence through employment." Diehl, supra note 179, at 1323 (footnotes omitted).

362. In Texas, for example, about $30 \%$ of divorces in 1983 were granted to couples married ten years or longer. Texas House Judiciary Report, supra note 243, at 61.

363. See, e.g., id. ("[G]iven the same education and career, a woman in American society will still earn only 60 percent of the salary of her male counterpart."). 
of cases, Texans cannot claim that a prohibition on permanent alimony simply anticipates emerging social realities.

Against these dubious justifications for Texas's continuing failure to provide some form of ex-spousal maintenance, one must weigh a number of very real costs. While Texas courts originally may have concluded that spousal support might weaken the institution of marriage, ${ }^{364}$ a more recent nationwide study has concluded that the unavailability of alimony in modern society discourages both marriage and child-rearing. ${ }^{365}$ The failure of Texas courts and lawmakers to provide some form of ex-spousal support also traps dependent spouses in abusive marriages, ${ }^{366}$ swells the welfare rolls, ${ }^{367}$ and may help to make Texas the most expensive state in which to get a divorce. ${ }^{368}$ There is even some

364. See supra notes $164-73$ and accompanying text.

365. See Elisabeth M. Landes, Economics of Alimony, 7 J. LEgAL STUD. 35, 36, 63 (1978) (finding that in states that prohibit alimony-at the time of the study, Texas, Delaware, and Pennsylvania-a smaller percentage of women marry, and those who do marry have fewer children).

366. See Hearings on Tex. S.B. 532 Before the House Jud. Comm., supra note 241 (testimony of Deborah Tucker, Texas Council on Family Violence) (tape on file with the author) ("We find in our work with battered women that there are a lot of women who stay in violent relationships until their children are grown and have been able to perhaps go through college or perhaps get out and be selfsupporting.").

367. Texas' failure to provide some form of permanent alimony increases burdens on the state's social services, a fact reflected in estimates of cost savings accompanying legislative proposals. See, e.g., Legislative Budget Board, Fiscal Note, Tex. S.B. 537 (Apr. 22, 1983); id., Fiscal Note, Tex. S.B. 632 (Apr. 21, 1983); but see id., Fiscal Note, Tex. S.B. 711 (Mar. 19, 1979) (anticipating an undetermined amount of increased costs for judicial administration).

A Texas study has found that nearly half of all displaced homemakers live below the poverty level. Hearings on Tex. H.B. 697 before the House Jud. Affairs Comm., 71st Leg., R.S. (Mar. 29, 1989) (testimony of Cecily Sims, legislative chair of the Women in the Law Section, State Bar of Texas) (A 1988 state-sponsored report says that "over 65 perent of Texas' displaced homemakers are living below the level at which the bureau of Labor Statistics estimates adequate to meet day-to-day expenses. Fortyseven percent of these people are living below the poverty level."). One legislative opponent of permanent alimony in Texas changed his position and introduced a spousal support bill in 1987 because "he found too many divorced mothers seeking state support." Poverty, Hopelessness Often the Result of Divorce for Texas Women, Children, Southwest Newswire Inc., Apr. 15, 1987. Clearly, "[t]he growing number of divorced women and children in serious need is a matter of profound public importance." Deborah L. Rhode \& Martha Minow, Reforming the Questions, Questioning the Reforms: Feminist Perspectives on Divorce Law, in DIVORCE REFORM AT THE CROSSROADS, supra note 215, at 193.

368. When a recent nationwide survey reported that Texas divorce lawyers charge more than their counterparts in other jurisdictions, the author speculated that since Texas is the only state without alimony, parties are fighting harder over the divisible assets. Karen Timmons, Texas Leads in Divorce Costs, UPI, Aug. 16, 1989 (LEXIS, NEXIS Library, UPI file) (quoting author-attorney Lois Brenner). The survey focused on "leading" divorce lawyers, rather than average lawyers and cases. The study's results may be skewed because Texas also led the the nation in "family assets" of clients of the lawyers surveyed-some $\$ 2.3$ million per family. Divorce costs might be expected to increase as the amount in controversy increases, alimony notwithstanding. Nonetheless, Harry Tindall, a prominent Texas family law practitioner, echoes Ms. Timmons' conclusion:

[T] here is no question that our divorce cases are more property-contentious than [in] any other jurisdiction in the United States. ... And why? Because if you represent the spouse with less earning capacity ... there's no remedy for that spouse other than the division of the property. .... Alimony can actually temper the quest to find every nickel and every dollar in every marital case.

Hearings on Tex. H.B. 697 Before the House Jud Affairs Comm., 71st Leg., R.S. (Mar. 29, 1989) (tape on file with the author).

The problem may not be unique to Texas. One author has suggested that the export of equitable distribution principles to common law jurisdictions is supported by matrimonial lawyers because it 
evidence that Texas is becoming, in its own small way, a "divorce haven" for husbands. ${ }^{369}$ When one adds to all of this the fact that there has never been any serious opposition to the merits of Texas ex-spousal support legislation, continuing statements by Texas courts that alimony is somehow against the state's public policy lose any semblance of credibility.

\section{B. Emerging Texas Community Property Doctrine}

Assuming that equitable considerations can play a role in the development and application of Texas community property law, as demonstrated in the first half of the twentieth century, one might expect some movement in the law to ameliorate the harsh results of the Texas Supreme Court's apparent conclusion in 1967 that permanent alimony is contrary to public policy, ${ }^{370}$ and its conclusion in 1977 that separate property cannot be divested on divorce. ${ }^{371}$ However, nothing of the sort seems to be occurring.

One particularly telling example is the development of Texas law on the characterization of professional goodwill. In a 1972 case, Nail v. Nail, ${ }^{372}$ the Fort Worth Court of Civil Appeals addressed a question of first impression: Can a doctor's goodwill be characterized as a property interest divisible at divorce? The court canvassed the case law, identified the majority and minority views nationwide, and decided a doctor's goodwill was property. ${ }^{373}$ A principal reason was that in the only divorce case the court of appeals could find even close to the point, the California Supreme Court had held a professional practice could have transferrable goodwill. ${ }^{374}$ The court explicitly rejected an argument that the award of an interest in professional goodwill was the equivalent of alimony. ${ }^{375}$

The Texas Supreme Court reversed, holding professional goodwill not to be property. ${ }^{376}$ The reasoning leaves much to be desired. While admitting that "solution of the problem is not easy" 377 and that "[w]e have found no case in point," 378 the court showed no inclination to fashion a result favorable to the community. Instead, the court began the opinion by mentioning the Texas public

increases the complexity of the law, and thus, the need for lawyers' services. See Smith, supra note 316, at $736 \mathrm{n} .252$.

369. As one particularly prominent example, the news media reported that Senator John Tower tried to get his divorce case moved to Texas because of the state's prohibition on permanent alimony. Moira Mulligan, Personalities, WASH. POST, Sept. 12, 1987, at D3. In 1983, a Texas divorce lawyer reported that "we're starting to get people [in our offices] who are coming to Texas to get a divorce." Kenneth Fuller, Hearings on Tex. S.B. 537 Before the Subcomm. on Civil Matters of the Sen. Jur. Comm., 68th Leg., R.S. (Apr. 25, 1983) (tape on file with the author).

370. Francis v. Francis, 412 S.W.2d 29, 33 (Tex. 1967).

371. Eggemeyer v. Eggemeyer, 554 S.W.2d 137, 139-40 (Tex. 1977).

372. 477 S.W.2d 395 (Tex. Civ. App.-Fort Worth), rev'd, 486 S.W.2d 761 (Tex. 1972).

373. Id. at 398.

374. The Fort Worth appeals court cited Mueller v. Mueller, 144, 301 P.2d 90 (Cal. 1956).

375. Nail, 477 S.W. at $399-400$.

376. Nail v. Nail, 486 S.W.2d 761 (Tex. 1972).

377. Id. at 763 .

378. Id. 
policy against permanent alimony, though simultaneously stating that the trial court's decree "purported to be" an exercise of the court's powers to divide the community estate. ${ }^{379}$ After selective citations to legal encyclopedias, ${ }^{380}$ and a nod to Texas authority suggesting that professional goodwill could be bought and sold, ${ }^{381}$ the court turned to the common law jurisdictions of New York, North Carolina, and Tennessee to illustrate that professional goodwill is exempt from forced sale. ${ }^{382}$ Notably absent from the Texas Supreme Court's discussion is any mention of the California divorce decision relied upon by the court of civil appeals.

In the two decades since Nail, every other community property jurisdiction has answered the professional goodwill question contrary to Texas, ${ }^{383}$ and the inequity of the Texas rule is becoming more and more apparent. ${ }^{384}$ In fact, some change may be on the horizon. In March 1992, while recognizing itself bound by the precedent of $\mathrm{Nail}$, the Corpus Christi appeals court noted that Texas's position was in the minority and added: "We question the fairness of the result ...."385 The Texas Supreme Court initially consented to review the decision, ${ }^{386}$ which typically indicates some dissatisfaction with the lower court's ruling. ${ }^{387}$ While the Texas Supreme Court then reversed its original action on procedural grounds, it did so with a rare written comment indicating a willingness to consider the issue in a future case. ${ }^{388}$

Another example of the extraordinarily restrictive approach taken by Texas courts toward novel property questions in recent years, despite the absence of alimony, may be found in the cases dealing with the characterization of enhanced value of separate-property stock in a closely held corporation. In the 1982

379. Id. at 762 .

380. Both the California Supreme Court in Mueller and the Fort Worth Court of Civil Appeals in Nail cited an American Jurisprudence comment that " $[\mathrm{t}]$ he better doctrine . . appears to be that good will ... exists in a professional practice ... [and] it would seem to be well settled that this is a species of good will which may be the subject of transfer." Mueller, 301 P.2d at 95; Nail, 477 S.W.2d at 398. The Texas Supreme Court's opinion, while citing other encyclopedia entries, omits any mention of the quoted language.

381. Nail, 486 S.W.2d at 763.

382. Id.

383. Grace Ganz Blumberg, Identifying and Valuing Goodwill at Divorce, 56 LAW \& CONTEMP. PROBS. 217 (Spring 1993).

384. Texas courts already have ameliorated some of the consequences of Nail by distinguishing between personal and corporate good will. See, e.g., Finn v. Finn, 658 S.W.2d 735 (Tex. App.-Dallas 1983, writ ref'd n.r.e.); Trick v. Trick, 587 S.W.2d 771 (Tex. Civ. App.-El Paso 1979, writ dism'd). The distinction is at least implicit in Nail, 486 S.W.2d at 763-64.

385. Guzman v. Guzman, 827 S.W.2d 445, 448 (Tex. App.-Corpus Christi 1992, writ granted), dism'd per curium as improvidently granted and denied, 36 Tex. Sup. Ct. J. 434 (Dec. 31, 1992).

386. The application for writ of error, raising as the sole ground for complaint the court of appeals' conclusion that "good will ... was not property subject to division by the court for purposes of the divorce," was granted June 13, 1992, with oral argument set for October 27, 1992. Guzman v. Guzman, 35 Tex. Sup. Ct. J. 822, 814 (Tex. 1992).

387. TEX. R. APP. P. 133(a).

388. While dismissing the application as improvidently granted, the court stated in a written order that its action was taken "[o]n procedural grounds, and without reference to the merits." 36 Tex. Sup. Ct. J. at 434. 
Vallone case, ${ }^{389}$ the issue was not presented squarely. ${ }^{390}$ Nonetheless, dicta in the opinion clearly disfavored a community property interest. ${ }^{391}$ In Jensen, ${ }^{392}$ decided a little more than a year later, the court so held.

Once again, the reasoning employed by the Texas Supreme Court is questionable. Texas was the last of the community property states to address the issue of characterizing closely held corporate stock ${ }^{393}$ and, in both Vallone and Jensen, the Texas Supreme Court claimed to be looking to other community property states for guidance. ${ }^{394}$ Unfortunately, the Texas Supreme Court either did not understand ${ }^{395}$ or ignored two crucial legal distinctions between Texas and other community property states. First, neither Jensen nor Vallone show any sensitivity to the fact that other community property jurisdictions view alimony as a method of adjusting the equities when closely held corporate stock is involved. ${ }^{396}$

Second, the Texas Supreme Court ignored a critical distinction in community property doctrine. Increased stock value in closely held corporations might commonly be expected to result from some combination of retained profit and uncompensated labor. In the majority of community property states, profits are considered separate property (the "American Rule"). In these jurisdictions, because profits are separate property and the fruits of one's labor are community, a typical result would be to apportion enhanced stock value between separate and community estates. ${ }^{397}$ Texas, however, follows the minority "Spanish Rule," characterizing rents and revenues of separate property as community

389. Vallone v. Vallone, 644 S.W.2d 455 (Tex. 1982).

390. It is not clear from the reported opinions or from the briefs whether Mrs. Vallone was seeking a portion of the retained corporate earnings as her community property interest, as reimbursement for increased value of her husband's separate property, or on some other theory. The Texas Supreme Court characterized the issue as: "Did the trial court abuse its discretion by ignoring community rights and equities which might have existed in the corporation?" Id. at 460 .

391. The decision refers repeatedly to a possible right of reimbursement, implying that the retained earnings would be considered to be separate property. Id. at 459.

392. Jensen v. Jensen, 665 S.W.2d 107 (Tex. 1984).

393. Idaho was the second-to-last community property state to address the issue. See Speer v. Quinlan, 525 P.2d 514 (Idaho 1973) (containing extensive discussion of the law of other community property jurisdictions).

394. The Texas Supreme Court in Vallone tabulated the results reached in other community property jurisdictions, 644 S.W.2d at 459 n.1, as did the court in Jensen, 665 S.W.2d at 109.

395. The possibility that the Texas Supreme Court simply misunderstood the law of other community property states is by no means remote. In Vallone, for example, the court cited as authoritative an Arizona decision overruled some two years before. James W. Paulsen, Comment, Closely Held Corporations in the Wake of Vallone: Enhancement of Stock Value By Community Time, Talent and Labor, 35 BAYLOR L. REV. 47, 76 (1983). The court also characterized the decisions from other states as all dealing with "reimbursement," despite the fact that four of the six cases cited do not mention the word, one distinguishes a reimbursement case from the principal case, and one is a significantly different type of reimbursement. Id. at 73.

396. For example, in Speer v. Quinlan, a case specifically cited by the Texas Supreme Court in Vallone, 644 S.W.2d at 459 n.1, the Idaho Supreme Court concluded its discussion of the factors to be considered in measuring enhanced stock value with the observation: "Any attempt to compensate Mrs. Speer for detriment that the community may have experienced because of the retention of the earned surplus must, of necessity, be inexact. ... In view of this opinion, the district court on remand may reconsider the issue of alimony." 525 P.2d at 325.

397. See, e.g., Cockrill v. Cockrill, 601 P.2d 1334 (Ariz. 1979). 
property. ${ }^{398}$ Thus, both profits on separate property investments and the fruits of community labor should be community. The academic literature ${ }^{399}$ and some court decisions ${ }^{400}$ recognize the danger of generalizing from American Rule to Spanish Rule jurisdictions and vice versa, so far as enhanced stock value is concerned. The Texas Supreme Court's opinions in Vallone and Jensen, however, show no indication that the court was aware of any conceptual problems. The court simply followed what it perceived to be the majority rule, without any analysis of distinctions that should have favored the community in Texas.

As is the case with personal goodwill, there may be some hopeful signs for the future. Post-Jensen decisions seem to favor an "enhanced value" standard in reimbursement cases. ${ }^{401}$ Accordingly, if the measure of the community's right to reimbursement for increased value of closely held stock should be "enhancement," and if the nonowner spouse can meet the pleading and proof requirements of Texas reimbursement doctrine, ${ }^{402}$ the practical result might be the same as if the Texas Supreme Court had developed a community-favoring doctrine in the first instance. ${ }^{403}$ In addition, because personal goodwill may well constitute some portion of the increased value of closely held corporate stock, a reevaluation of Texas' position on goodwill might eventually lead to a similar rethinking of the stock issue.

A third example, the characterization of a professional degree, has not received as much discussion in Texas as has goodwill or closely held stock shares. The leading case, Frausto v. Frausto ${ }^{404}$ followed the majority trend in other jurisdictions, ${ }^{405}$ declining to find a professional degree to be "property."

398. The minority or "Spanish Rule" states at the time were Texas, Idaho, and Louisiana; Arizona, California, Nevada, New Mexico, and Washington were the majority or "American Rule" states. William Q. De FuniaK \& Michael J. Vaughn, Principles of Community ProperTy $\$ 71$, at 181 (2d ed. 1971).

399. An influential Arizona article, for example, specifically excluded Texas law from the analysis as being too dissimilar to provide a useful comparison. Jan Mark Adler, Arizona's All-or-Nothing Approach to the Classification of Gain From Separate Property: High Time for a Change, 20 ARIZ. L. REV. 597, 598 n.5 (1978); see also Fred C. Weekley, Appreciation of A Closely-Held Business Interest Owned Prior to Marriage-Is It Separate of Community Property?, 7 CoMmUNITY PROP. J. 261, 271 (1980).

400. See, e.g., Speer, 525 P.2d at 319-20.

401. See, e.g., Penick v. Penick, 783 S.W.2d 194, 196 (Tex. 1988) (enhancement as the standard of reimbursement for capital investment in real estate); Anderson v. Gilliland, 684 S.W.2d 673, 675 (Tex. 1985) (enhancement as the standard of reimbursement for improvements to real estate).

402. Reimbursement is an equitable doctrine. Penick, 783 S.W.2d at 197. The burden of pleading and proof is on the claimant. Vallone, 644 S.W.2d at 459 . An extraordinarily restrictive rule of specificity in divorce pleadings announced in Vallone, however, was overruled implicitly in Jensen. 665 S.W.2d at 110 (Robertson, J., concurring).

403. See, e.g., James W. Paulsen, Jensen III and Beyond: Exploring the Community Property Aspects of Closely Held Corporate Stock in Texas, 37 BAYLOR L. REV. 653, 716-23 (1985).

404. 611 S.W.2d 656 (Tex. Civ. App.-San Antonio 1981, writ dism'd).

405. In recent years, many courts (and nearly as many commentators) have addressed the divorce issues raised when a professional degree is earned during marriage. One good recent article, containing helpful appendices listing decisions and scholarly writing, is Linda L. Schleuter \& Kimberly Gott, The "Diploma Dilemma": Whether a Professional Degree or License Should be Treated as a Professional Asset on Divorce, 15 COMmUNITY PROP. J. 28 (1988); see also Michael G. Walsh, Annotation, Spouse's 
However, the consequences of this decision in Texas are extraordinarily harsh. If a degree is not property, neither alimony nor reimbursement for the community's investment in one spouse's education is possible. ${ }^{407}$

The Frausto decision has been characterized, with some justification, as involving "a minimum of analysis" 408 and as being "defective in numerous aspects." ${ }^{409}$ Nonetheless, the court's reasoning process is reasonably clear. The San Antonio court recognized that the case was one of first impression in Texas, ${ }^{410}$ and that there was some conflict of authority in other jurisdictions. ${ }^{41}$ Turning to out-of-state authority for guidance, the court noted that the only jurisdiction finding a property interest in a professional degree, Kentucky, ${ }^{412}$ is a common law state. ${ }^{413}$ In contrast, the court believed it had identified two community property jurisdictions that refused to find a property interest in a professional degree. ${ }^{414}$ One easy gauge of the depth of the court's analytical problems is that Colorado, the "community property state" most discussed in the Frausto opinion, is not a community property jurisdiction. ${ }^{415}$ Moreover, while citing language from a Colorado opinion implying that alimony or maintenance would be an appropriate way to adjust the equities, ${ }^{416}$ the Frausto court never drew the obvious conclusion that the unavailability of alimony in Texas could justify a different resolution of a novel issue.

The San Antonio court in Frausto apparently felt it was restricted by previous Texas Supreme Court decisions-the ruling in Nail that professional goodwill is not property and the warnings in Eggemeyer and Campbell that protection of

Professional Degree or License as Marital Property for Purposes of Alimony, Support, or Property Settlement, 4 A.L.R. 4TH 1294 (1981).

406. Frausto, 611 S.W.2d at 659.

407. Id. at 660; see also Halbert v. Halbert, 794 S.W.2d 535 (Tex. App.-Tyler 1990, no writ).

408. W. Bruce Stanfill, Comment, The Equity/Property Dilemma: Analyzing the Working Spouse's

Contributions to the Other's Educational Degree at Divorce, 23 Hous. L. REV. 991, 1001 (1986).

409. Id. at 1014.

410. 611 S.W.2d at 658.

411. The Frausto decision also has been criticized for a sloppy analysis of non-Texas authority. One commentator states that "[t]he court failed to notice or discuss at least nine other cases in six different states arriving at opposing conclusions under similar case facts." Stanfill, supra note 408, at 1019.

412. Inman v. Inman, 578 S.W.2d 266 (Ky. Ct. App. 1979).

413. Frausto, 611 S.W.2d at 659.

414. Id. at 658-59. The jurisdictions cited are California (Marriage of Aufmuth, 152 Cal. Rptr. 668 (Cal. Ct. App. 1979) and Todd v. Todd, 78 Cal. Rptr. 131 (Cal. Ct. App. 1969)) and Colorado (Marriage of Graham, 555 P.2d 527 (Colo. Ct. App. 1976)).

415. Colorado adopted the original version of the Uniform Marriage and Divorce Act in 1971. W. S. MCClanahan, COMMUNITY PROPERTY LAW IN THE UNITED STATES $\$ 14: 3$ (1982). In consequence, well before the Frausto opinion, Colorado courts were declaring that "Colorado is not a community property state, and that law does not control here." Marriage of Ellis, 538 P.2d 1347 (Colo. Ct. App. 1975), aff'd, 552 P.2d 506 (Colo. 1976). This was an elementary mistake on the part of the Texas court. The decision cited by the Frausto court as evidencing the "community property" law of Colorado noted the distinction between California community property law and Colorado law, citing the Colorado marital property statute. Graham, 555 P.2d at 529.

416. Frausto, 661 S.W.2d at 659. In Aufmuth, another case cited in Frausto, the California Court of Appeal noted in partial justification for its decision that "the trial court must have considered husband's earning capacity in awarding spousal and child support." 152 Cal. Rptr. at 677. 
separate property had assumed constitutional dimensions. ${ }^{417}$ The court admitted that "there are inequities which may result from the failure to compensate the spouse who supports the other spouse through college or professional school," ${ }^{418}$ but deferred to the trial court's wide discretion in dividing the community estate as Texas' solution to the problem. ${ }^{419}$ Of course, in Frausto, ${ }^{420}$ as in many cases in which the value of a professional degree might become an issue, ${ }^{421}$ there is little or no community property to be divided.

Other examples might be offered, ${ }^{422}$ and reasonable minds might differ on the extent to which the primary examples chosen-personal goodwill, enhancements to closely held stock and professional degrees - constitute a genuine trend in Texas jurisprudence. Nonetheless, whether contrary examples could be offered or not, it seems clear that Texas common law is not adjusting as well as it did in the first half of the twentieth century (if it is adjusting at all) to newly restrictive community property doctrine. Nor has the recent tendency of Texas courts to examine the law of other community property jurisdictions resulted in any increased sensitivity to Texas' unique position. Instead, the decisions seem

417. Frausto, 611 S.W.2d at 659.

418. Id.

419. Id.

420. The value of the community estate in Frausto is difficult to estimate from the facts set out in the opinion. The San Antonio court, however, admitted that "it appears relatively small." Id. at 658 n.2.

421. A scholarly commentary noted in Frausto sets out the situation well: "When a divorce occurs shortly after completion of the education there are little or no community assets to be equally divided. In addition, the separate property of the wife likely has been consumed for tuition and living expenses. A decree denying some form of compensation to the comparatively uneducated wife in these situations would indeed be harsh." James N. Castleberry, Jr., Constitutional Limitations on the Division of Property Upon Divorce, 10 ST. MARY's L.J. 37, 56 (1978). Likewise, in Marriage of Washburn, 677 P.2d 152, 155 (Wash. 1984), the Washington Supreme Court described as "so familiar as to be almost a cliche" the situation in which "[b]ecause the family spent most of its financial resources on the degree, there may be few or no assets to be distributed."

422. For example, Texas' leading case on retirement benefits sets out a very restrictive rule for determining the community's interest. Berry v. Berry, 647 S.W.2d 945, 947 (Tex. 1983) (stating pro rata share "frozen" as of the moment of divorce, with no consideration for postdivorce inflation). The case contains no reference to the "no alimony" rule or to Eggemeyer or Cameron. Only four years earlier, however, the "no alimony" policy did intersect the pension question obliquely. In Eichelberger $v$. Eichelberger, 582 S.W.2d 395 (Tex. 1979), the Texas Supreme Court resisted the suggestion to fashion a rule to permit nonemployee spouses to reach railroad retirement benefits under a federal statute permitting garnishment for "alimony," in part because of the "long-standing public policy against alimony" in Texas. 582 S.W.2d, at 402.

Fortunately, there are some indications that the Texas rule on postdivorce increases in retirement pay may be becoming less restrictive. In Grier v. Grier, 731 S.W.2d 931 (Tex. 1987), the Texas Supreme Court permitted a former spouse to share in military retirement benefits, including postdivorce "increases which may occur other than increases attributable to elevation in rank or services rendered by the military spouse after the date of divorce." Id. at 933. This language has been read as permitting a former spouse to share in post-divorce changes in a pension plan, "bridge" benefits and cost-of-living adjustments. Phillips v. Parrish, 814 S.W.2d 501, 504-05 (Tex. App.-Houston [1st Dist.] 1991, writ denied); see also John Hopwood, Susan Roberts \& Jim Paulsen, Selected Current Issues in Community Property Aspects of Retirement Plans, 39 BAYLOR L. REV. 1199, 1205 (1987) ("[I]t is clear that cost of living increases and inflation can now be taken into account, in at least some cases, mitigating the otherwise harsh effects of Berry."). 
to be combining the worst of both worlds-following restrictive decisions in other jurisdictions without consideration of the "safety valve" alimony might offer (for example, in cases concerning closely held stock and professional degrees), while declining to follow the lead of other community property states when the result might seem to smack of alimony (for example, professional goodwill). Consequently, the policy stated in Cameron-that Texas courts will resist the temptation to "resolve the problem of the state's lack of alimony laws ... by indirection" ${ }^{\prime 23}$ - seems to be carrying through with a vengeance into novel characterization issues.

\section{The Possibility of Judicial Reform}

With the restrictive separate property doctrine of Eggemeyer and legislative inaction, the outlook for post-divorce spousal support in Texas appears grim. The dark cloud of Eggemeyer, however, may have a silver lining. Scholarly commentary on the case by two of its few supporters has produced a very new (or resurrected a very old) theory to do justice between divorcing spouses despite the strictures of Eggemeyer. ${ }^{424}$ Dean James Castleberry and Professor Joseph McKnight both advocated the theory, which calls for an award of money damages in a suit for breach of marital contract, in articles published in 1978. ${ }^{425}$ While both authors advocate a breach of contract action, they reach their conclusion from very different starting points-Castleberry looks to older Texas decisions on the nature of the marriage relationship, ${ }^{426}$ and McKnight analogizes to the California Marvin v. Marvin ${ }^{427}$ "palimony" decision. ${ }^{428}$

To date, no Texas appellate court has considered whether a breach of marital contract theory can be used as an end-run around Eggemeyer. ${ }^{429}$ This is

423. Cameron v. Cameron, 641 S.W.2d at 218 (Tex. 1982) (order of quoted language reversed).

424. In a similar fashion, scholarly commentary on the United States Supreme Court's restrictive retirement benefit decision in Hisquierdo v. Hisquierdo, 439 U.S. 572 (1979) suggests another creative argument. Since Hisquierdo repeatedly suggests the use of alimony to compensate for the harsh consequences of federal preemption, and since Texas permits no alimony, the door might be open for the creation of federal common law alimony in Texas in some circumstances, no matter how contradictory that concept might sound. See William A. Reppy, Jr., Community and Separate Interests in Pensions and Social Security Benefits After Marriage of Brown and ERISA, 25 UCLA L. REV. 417, 508-11 (1978).

425. Castleberry, supra note 265, at 67-71; McKnight, supra note 267, at 128-30.

426. Castleberry, supra note 265 , at 67-69.

427. 557 P.2d 106 (Cal. 1976).

428. McKnight, supra note 267 , at 128 n.171.

429. The breach of contract theory, however, has made an appearance in at least one trial-level skirmish. In Dickson v. Dickson, No. 78-34542, 247th District Court, Harris County, Texas, Mrs. Dickson claimed her husband had breached an oral agreement to "love, honor and cherish" her, asking for $\$ 500,000$ in damages. Nene Foxhall, Divorce With a Twist, Houston CHRONICLE, June 28, 1979, at B8. Mrs. Dickson claimed that she worked so her husband could attend medical school, "agreeing that each would share in the lifetime future benefits of such a medical education." Id. In a press statement, Mrs. Dickson's lawyer linked the decision to advance a breach of contract claim to no-fault divorce, stating, "Texas law is faced with a need to devise a rational approach to the disposition of claims unrelated to the grounds for divorce." Id.

The trial court initially denied the husband's objections to the theory, though commenting that the case "would definitely be precedent-setting in Texas." Rick Barrs, Divorce Suit Says Husband 
unfortunate, because a suit by a spouse to recover damages for breach of a contract of support would stand a fair chance of success on the merits. Moreover, effective advocacy of this theory could expose the inherent contradiction in Texas's supposed public policy prohibition on alimony, force a reexamination of Eggemeyer's rationale, and highlight the fact that the Texas Legislature does not bear sole responsibility for the failure of the state's legal system to provide basic support for divorcing spouses.

In evaluating the potential for a breach of contract action, the threshold question is whether marriage is a contract. Dean Castleberry identified three distinct historical positions in Texas law: Marriage is a contract, a status, or both. ${ }^{430}$ For Texas courts, the chief legal hurdle facing a breach of marital contract suit would be the bald statement in a 1913 Texas Supreme Court decision, Grigsby v. Reib, ${ }^{431}$ that "[m]arriage is not a contract, but a status created by mutual consent of one man and one woman." 432 This language was pivotal in the decision in Gowin v. Gowin to prohibit a suit for breach of a contract of marital support, ${ }^{433}$ and it has never been repudiated. It is, however, highly suspect. ${ }^{434}$ In fact, the Texas Supreme Court has since glossed over its earlier denial of contract theory, stating that "[i]n the Grigsby case, this Court announced that the marriage was more than a contract; it is a status." 435

A better view of the law is that marriage is a status arising from a contract or, phrased somewhat differently for purposes of this analysis, a contract subject to intense legal regulation. Unlike some states, ${ }^{436}$ Texas does not, by statute, explicitly declare marriage to be a civil contract. Nonetheless, despite Grigsby, the view that marriage is a civil contract is firmly established in Texas case law. ${ }^{437}$ Moreover, even if the relationship is transformed from a contract to a status at the moment of marriage, ${ }^{438}$ this may make no real difference. ${ }^{439}$ In

Violated "Oral Contracts," Houston Post, June 29, 1979, at B5. The judge later reversed his ruling because, according to press reports, the husband's lawyer had convinced him in later arguments that any marriage contract must be in writing. Rick Barrs, Oral Contract in Marriage Vow Claim Rejected, Houston POST, Oct. 10, 1979, at A15. These arguments evidently became quite heated at points. See Rick Barrs, Judge, 32, No Pushover in Courtroom, Houston PosT, Oct 14, 1979, at A10 (reporting a "confrontation" with husband's counsel).

430. Castleberry, supra note 265, at 67-69. Dean Castleberry recognizes, however, that decisions from all periods acknowledge that marriage is, to some extent, a contract. Id. at 69 .

431. 153 S.W. 1124 (Tex. 1913).

432. Id. at 1130 .

433. See supra notes $144-46$ and accompanying text.

434. Dean Castleberry views Grigsby's analysis of the nature of the marriage relationship as "clearly incorrect." Castleberry, supra note 265, at 67 . The circumstances of Grigsby were not ideal. The case involved a question of common law marriage. The putative wife was a whorehouse madam who continued to ply her trade and use her own name while "married" to Mr. Grigsby. She assumed Grigsby's name only after his death, in order to press her claim against the estate. $153 \mathrm{~S}$.W. at 1124 .

435. Ex parte Threet, 333 S.W.2d 361, 364 (Tex. 1960) (emphasis added).

436. See ClaRK, supra note $18, \$ 2.2$, at $31 \mathrm{n} .1$ (discussing several state statutes).

437. For example, in Wilemon v. Wilemon, 250 S.W. 1010, 1012 (Tex. Comm'n App. 1923, opinion adopted), citing four prior decisions, the court stated, "By the laws of Texas, marriage is a civil contract."

438. This is the view taken in Gonzales v. Gonzales, 300 S.W. 20, 22 (Tex. Comm'n App. 1927, opinion adopted), a decision roughly contemporaneous with Grigsby. 
deciding to give effect to another state's divorce decree, for example, the Texas Supreme Court has remarked that "[a]n analogy between an obligation arising out of the marriage status and one arising under a contract seems entirely valid." 440

To be sure, the marriage relationship is heavily regulated by the state. The legislature may prescribe "the age at which parties may contract to marry, the procedure or form essential to constitute marriage, the duties and obligations it creates, its effects upon the property rights of both, present and prospective, and the acts which may constitute grounds for its dissolution." however, fairly can be said to have "preempted" contractual obligations of spousal support or set out exclusive remedies for breach of the marriage contract. ${ }^{442}$

Assuming that a court concludes that marriage rests on a contract, as it obviously does, an action for breach of support obligations might still run afoul of some "public policy" prohibition, as was the case in Gowin. The situations, however, are not identical. While the courts in Gowin believed that interspousal suits would "endanger the institution of marriage and would therefore be against

439. McKnight, for example, argues that there is no inconsistency between simultaneously maintaining a suit for dissolution of the marital status and breach of the marriage contract. McKnight, supra note 267 , at 128 .

440. McElreath v. McElreath, 345 S.W.2d 722, 727 (Tex. 1961).

441. Maynard v. Hill, 125 U.S. 190, 205 (1887). Because of the extent of government control, Bishop argued that it was more practical to think of marriage as sui generis, rather than as a very peculiar contract:

And when the differences are pointed out, we perceive that they have covered every quality of the marriage and left nothing of the contract. To term it, therefore, a contract, is as great a practical inconvenience as to call a certain well-known engine used for propelling railroad cars "a horse," and add, "but it differs from other horses in several important particulars," which particulars of dissimilitude must be specifically explained. It would be more convenient to use at once the word locomotive.

2 JOEL PRENTISS BISHOP, COMMENTARIES ON THE LAW OF MARRIAGE AND DIVORCE AND EVIDENCE IN MATRIMONIAL SUITS 34 (1852).

442. The author's view is contrary to the position taken by the Texas Supreme Court in Gonzales, 300 S.W. at 22 :

Since the state is the repository of that comprehensive power [to regulate marriage], its enactments must be examined to ascertain what has been granted to the [husband and wife] and (thus, by elimination) what has been withheld from them. What has not been granted in express terms, or by implications equally clear, has been withheld.

The notion that there are no rights and duties arising out of the marriage relationship, other than those distinctly specified by state law, is very questionable. On the facts, the Texas Supreme Court's reasoning in Gonzales can perhaps be understood. Mrs. Gonzales was suing to reclaim her separate funds expended because her husband refused to meet his support obligations. Because legislation provided for the husband's liability to third parties for "necessaries," as well as criminal penalties for non-support, Texas lawmakers arguably had spoken to the subject. Nonetheless, the Gonzalez court's decision to deny reimbursement is exceptionally conservative, even for the time (as is true for Gowin and Cunningham).

In a situation much akin to that presented in Gonzalez, the New York Court of Appeals unanimously granted the wife a cause of action, remarking that "[t]he plainest principles of justice require that a wife should have some adequate legal redress upon such a state of facts ..., and the beneficial character of our legislation removing the former disabilities of married women could not be evidenced more forcibly than it is in its application to the present case." De Brauwere v. De Brauwere, 96 N.E. 722, 723 (N.Y. 1911). 
public policy," ${ }^{443}$ these considerations do not apply with equal force against a suit for breach of contract. First, assuming that the suing spouse would join an action for breach of contract with a suit for divorce, the public policy favoring marriage would never be implicated because the marriage had already failed. ${ }^{444}$ Second, public policy has changed in the sixty-plus years since Gowin. While the Gowin decision pointed to the interspousal immunity doctrine as evidence of public policy promoting family harmony, even at the expense of justice between the parties, that doctrine has since been discredited in Texas. ${ }^{445}$ Third, because Texas courts and lawmakers now approve of contractual alimony agreements, even though made in contemplation of divorce, ${ }^{466}$ it is difficult to imagine any public policy that would still prohibit an action to recover damages for breach of a similar express or implied contract made before or during marriage.

A more direct "public policy" objection could also be made against an action for breach of an express or implied marital contract. Opponents could argue that if alimony is contrary to public policy per se, then a contract-based suit is so similar to alimony that it likewise should be barred. The answer to this argument has already been suggested, however. Alimony is not really contrary to public policy at all, notwithstanding loose language to that effect in some decisions. ${ }^{447}$ To reiterate, if alimony were truly contrary to public policy, then the Texas Supreme Court in Francis should not have permitted use of the courts to enforce a contractual alimony agreement. ${ }^{48}$ As explained, however, the

443. Gowin v. Gowin, 264 S.W. 529, 537 (Tex. Civ. App. 1924).

444. The appeals court in Cunningham recognized that the public policy favoring marriage had no application to a suit for postdivorce support because "the integrity of the home has already been destroyed; the marriage relation has been dissolved." Cunningham v. Cunningham, 299 S.W. 483,487 (Tex. Civ. App. 1927), rev'd 262, 40 S.W.2d 46 (Tex. 1931); accord Castleberry, supra note 265 ("If a happy marriage exists, there will be no reason to assert the cause of action.").

445. In Bounds v. Caudle, 560 S.W.2d 925, 927 (Tex. 1977), for example, the court stated, We recognize fully the importance of the family unit in our society. . . . However, ... [t] peace and harmony of a home which has already been strained to the point where an intentional physical attack could take place will not be further impaired by allowing a suit to be brought to recover damages for the attack.

In addition, as jaundiced practitioners might be heard to observe, a substantial payment by the assaulterspouse's insurer sometimes has a truly wondrous effect on a previously strained marital relationship.

446. It was once said that a contract tending to promote divorce is void. See Corgey v. McConnell, 260 S.W.2d 99, 102-03 (Tex. Civ. App.-El Paso), aff'd, 262 S.W.2d 944 (Tex. 1953). Nonetheless, the Texas Supreme Court has approved contracts for alimony. The Texas Family Code codifies this result. See TEX. FAM. CODE ANN. \& 3.631(a) (West 1993). The legislature also has supplied a ground for divorce which in practice is virtually defenseless. TEX. FAM. CODE ANN. § 3.01 (West 1993).

447. See supra ntoes $228-32$ and accompanying text.

448. A humorous but accurate example of how the reasoning should run, if some aspect of a contract were found to be against public policy, is the fictitious case of Marrowbone $v$. Marrowbone, in which a British court declines to hear any suits for divorce, on the theory that marriage itself is against public policy.

In all matrimonial transactions ... the element of skill is negligible and the element of chance predominates. This brings all marriages into the category of gaming (see Wagg $v$. Chief Constable of Ely), and therefore I hold that the Court cannot according to law assist or relieve the victims of these arrangements, whether by way of restitution, separation, or divorce.

Allan P. Herbert, UnCOMMON LAW 99 (International Polygonics, Ltd. 1991) (1935). 
Cunningham decision did not actually state that alimony is against public policy. ${ }^{499}$ The court simply observed that, in 1841 , "there was a change in the public policy of the Republic" 450 and that, thereafter, courts had no legislative authority to grant alimony.

A suit for breach of marital contract would serve the useful purpose of exposing this supposed "public policy" against alimony for what it really is-an extraordinarily inartful way of saying that Texas courts have no explicit statutory authority to grant alimony. For a Texas contract truly to be contrary to public policy, that contract must be "contrary to statute law or ... immoral in itself, and the injury to the public must be clearly apparent." 451 No Texas statute prohibits alimony. Public policy in Texas favors utmost freedom of contract. ${ }^{452}$ State statutes explicitly permit premarital contracts ${ }^{453}$ and agreements concerning division of property at divorce; ${ }^{454}$ moreover, "there is no policy reason for distinguishing between premarital and post-marital contracts." ${ }^{\text {,455 }}$ Public policy in the other forty-nine states favors at least some form of alimony, however transitional or "rehabilitative." The failure of Texas courts to provide any form of postdivorce ex-spousal support, no matter how aggravated the circumstances, discourages marriage, traps dependent spouses in abusive marriages, encourages forum-shopping, increases litigation expense, swells the welfare rolls and defeats the life-long expectations of innocent spouses. ${ }^{456}$ Under these circumstances, a Texas court applying normal legal standards would be hard-pressed to sustain a "public policy" objection to enforcement of a marital contract.

Of course, an action for breach of the marital contract would not be a panacea. The parties would have to establish the existence and terms of a contract, whether by premarital agreement, marriage vows, a course of conduct during marriage, or otherwise. ${ }^{457}$ Estoppel or detrimental reliance might also

449. See supra notes $130-31$ and accompanying text.

450. 40 S.W.2d at 47.

451. Nedow v. Nicholson, 381 S.W.2d 723, 724 (Tex. Civ. App.-Houston [1st Dist.] 1964, writ ref'd n.r.e.).

452. Huey v. Brand, 92 S.W.2d 505, 508 (Tex. Civ. App.-Amarillo 1936), aff'd sub nom. Borger v. Brand, 118 S.W.2d 303 (Tex. 1938). Ironically, even the Eggemeyer decision might lend some support to a breach of contract suit. Under the Texas Constitution, the government is prohibited from interfering with contractual obligations. TEX. CONST. art. I, $\$ 16$. If Eggemeyer has resurrected substantive due process decisions of the 1920 s, then it seems equally reasonable to raise a due process bar to any vague "public policy" standing in the way of contractual obligations, or to invoke cases of the same vintage prohibiting the impairment of contractual obligations. See, e.g., Langever v. Miller, 76 S.W.2d 1025, 1028 (Tex. 1934) (invalidating debt relief statute, though acknowledging United States Supreme Court authority to the contrary); Reef v. Mills Novelty Co, 89 S.W.2d 210 (Tex. 1936) ("“N] o reason occurs for denying to the parties the right, so long as no statute is infringed, to bind themselves to each other as they see fit, with respect to obligations imposed by the contract.").

453. TEX. FAM. CODE ANN. $\$ 5.46$ (West 1993).

454. Id. \$\$ 5.52-.55.

455. J. Thomas Oldham, Divorce, Separation and the Distribution of Property $\$ 4.06$, at 4-34 (1992).

456. See supra notes $358-63$ and accompanying text.

457. Typical marriage vows-to love, honor, and support "till death do us part"-might well create a contract, as was argued in the Dickson litigation. See supra note 429. If the wedding drew a good crowd, or if the couple decided to record the event on videotape, problems of proof would be minimal. 
play a role. For at least some claims, the contract might have to be in writing. ${ }^{458}$ Defenses such as prior breach and failure to mitigate damages would also be available. In short, judicial recognition of a claim for breach of marital contract might well increase litigation expense and interject questions of fault into a no-fault divorce.

These problems, however, are not likely to materialize. The principal effect of judicial recognition of a breach of marital contract principle simply would be to give dependent spouses some basis upon which to negotiate a settlement, thus restoring some of the bargaining power lost by the introduction of no-fault divorce. Even more likely, a decision by some court to entertain a breach of contract action might "encourage" the Texas Legislature to break its twenty-year deadlock and pass some spousal maintenance legislation perhaps including an "exclusive remedy" clause. ${ }^{459}$

VI

\section{CONCLUSION}

As Professor John Sampson, Texas's most consistent advocate of a statute for the maintenance of former spouses, has observed, the fact that Texas is the only state with no provision for ex-spousal support "has not caused Texans to hang their heads in shame .... . Rather, the reaction has been much like the proud mother who returned from a massive military parade to brag that "The entire Fifth Army was out of step except my son John." 460 As has been demonstrated, the perverse pride Texans take in being different from everyone else, and the myths that have grown up around the "no permanent alimony" doctrine, have no basis in fact or logic.

The Texas "public policy" prohibition on permanent alimony does not go back to 1841. It is not a legislative quid pro quo for the benefits of the community property system. It is not some consequence of the hardy frontier heritage. Rather, the prohibition of permanent alimony is a twentieth century invention of Texas courts, made in ignorance of prior law and compelled neither by legislation nor by the state's judicial history. There never has been a deliberate, reasoned pronouncement that alimony is against public policy, either from the legislature or the courts. In short, the Texas prohibition on permanent alimony is an historical accident not worthy of veneration.

A study of Texas history shows more than this, however. It reveals that early Texas courts were cognizant of their broad powers, willing to deviate from the common law when deviation made sense, and capable of placing concern for

458. See TEX. FAM. CODE $\$ \S 5.46,5.52-.55$ (West 1993) (premarital agreements and agreements in contemplation of divorce must be in writing).

459. There is no logical reason why, in the absence of legislative language specifically negating contractual remedies, legislation should "preempt" a breach-of-marriage-contract action. Should the legislature decide to take this route, however, great care would need to be taken to assure that contractual alimony agreements were not prohibited by inadvertence.

460. Guthrie \& Sampson, supra note 321, at 298. 
needy spouses above strict rules of property division. By contrast, more recent decisions are often characterized by a lack of serious analysis, mechanical adherence to "rules" of questionable application and an exhaltation of mindless formalism over just results.

In one sense, however, Texas jurisprudence may be coming full circle. There is a remarkable similarity between the contract theory underlying Sam Houston's divorce and the contract theory now suggested as a partial solution to the inequities caused by the failure of courts and legislators to provide any form of spousal maintenance. After all, if the court of history judges Sam Houston not to be a bigamist, one good reason would be his lawyers' argument that, in the absence of affirmative legislation, Texas "[c]ourts have, alone, the power [of] decreeing performance[,] awarding damages, or exonerating the party from the obligation" of the marriage contract. ${ }^{461}$ It would be a pleasurable irony indeed if a piece of genuine Texas legal history could help to undo the consequences of a more recent Texas myth-the spurious "public policy" forbidding permanent alimony. 